\title{
HYDROGEOLOGY AND GROUND-WATER FLOW \\ IN THE CARBONATE ROCKS OF \\ THE LITTLE LEHIGH CREEK BASIN, \\ LEHIGH COUNTY, PENNSYLVANIA
}

By Ronald A. Sloto, L. DeWayne Cecil, and Lisa A. Senior

U.S. GEOLOGICAL SURVEY

Water-Resources Investigations Report 90-4076

Prepared in cooperation with the

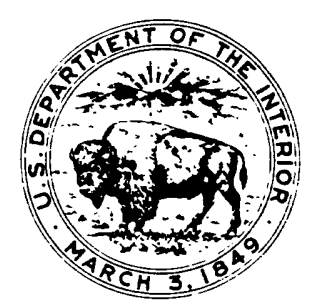

DELAWARE RIVER BASIN COMMISSION,

PENNSYLVANIA DEPARTMENT OF ENVIRONMENTAL RESOURCES,

LEHIGH COUNTY AUTHORITY,

CITY OF ALLENTOWN, and

SOUTH WHITEHALL TOWNSHIP

Lemoyne, Pennsylvania

1991 
U.S. DEPARTMENT OF THE INTERIOR

MANUEL LUJAN, JR., Secretary

U.S. GEOLOGICAL SURVEY

Dallas L. Peck, Director

For additional information write to:

District Chief

U.S. Geological Survey

840 Market Street

Lemoyne, Pennsylvania 17043-1586
Copies of this report can be purchased from:

U.S. Geological Survey Books and Open-File Reports Section Federal Center, Building 810

Box 25425

Denver, Colorado 80225 


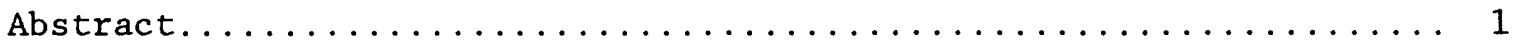

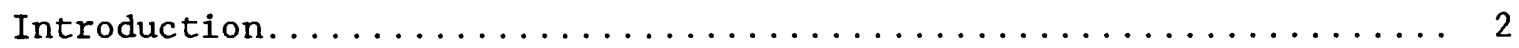

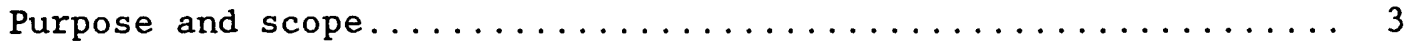

Location and physiography........................... 3

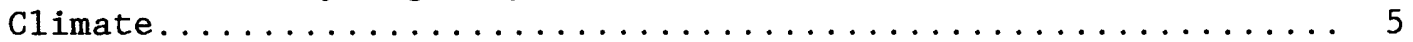

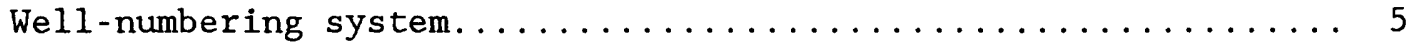

Previous investigations.............................. 6

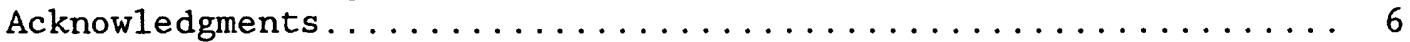

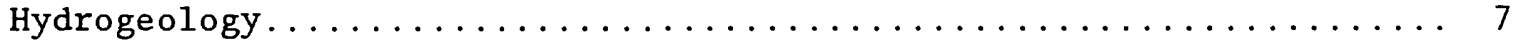

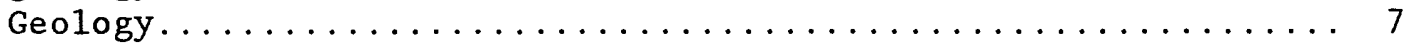

Stratigraphy of the carbonate rocks.............. 7

Leithsville Formation................... 8

Allentown Dolomite..................... 9

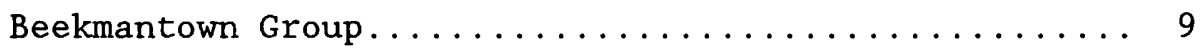

Jacksonburg Limestone.................... 9

Stratigraphy of the noncarbonate rocks............. 10

Structure and regional setting................. 10

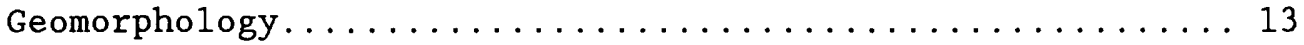

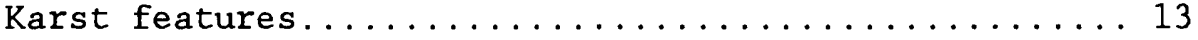

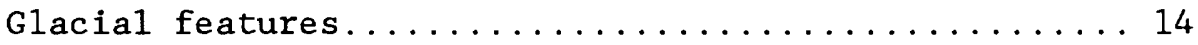

Hydrology . . . . . . . . . . . . . . . . . . . . . 14

Hydraulic characteristics of carbonate rocks.......... 15

Hydraulic characteristics of noncarbonate rocks.......... 17

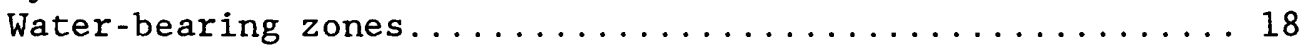

Ground-water/surface-water relations............... 19

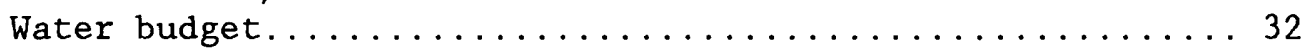

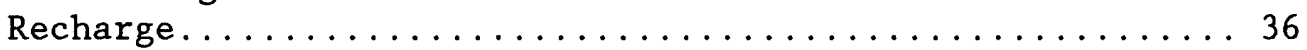

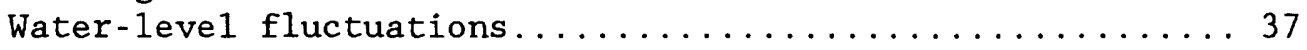

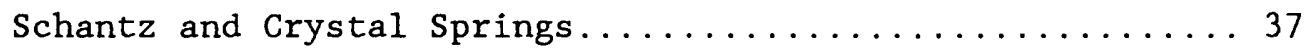

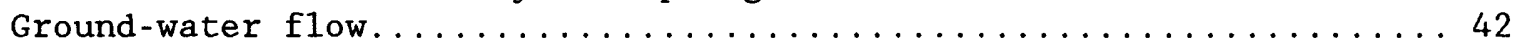

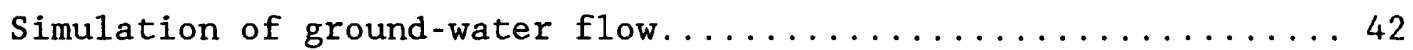

Description of flow model................. 43

Simplified conceptual model................. 43

Discretization........................... 46

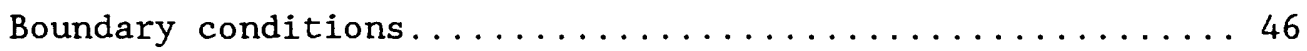

Model calibration............................... 49

Aquifer characteristics................. 51

Pumping rates......................... 54

Simulated water-table surface.............. 56

Simulated average water budget............. 56

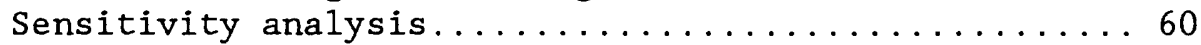

Reliability of model simulations............663

Simulated effects of increased ground-water development....6 63

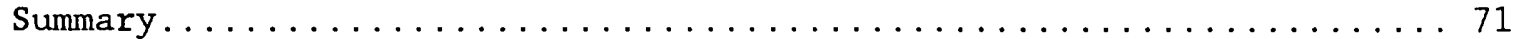

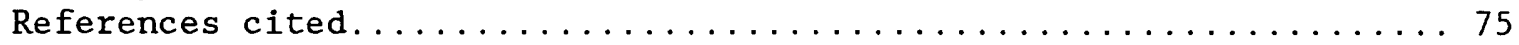




\title{
ILLUSTRATIONS
}

\author{
PLATES \\ [In Pocket]
}

Plate 1.--Geology and location of selected wells and springs, Little Lehigh Creek basin and vicinity, Berks and Lehigh Counties, Pennsylvania

\section{FIGURES}

Figure 1.--Map showing location of Little Lehigh Creek basin......4 4

2.--Map showing physiographic provinces.............. 5

3.--Generalized stratigraphic column for Schuylkill and Lehigh Valley sequences................ 8

4.--Geologic sections showing carbonate and noncarbonate rocks near the Lehigh-Berks County border....................... 12

5.--Block diagram showing the relation between carbonate bedrock and surface topography in a karst area.......13

6. - -Map showing extent of Illinoian drift in Lehigh County... 14

7.--Geophysical logs of well LE-1319............... 18

8. --Streamflow and base-flow hydrographs of Little Lehigh Creek near Allentown, 1965 and $1984 \ldots \ldots \ldots 21$

9. - Map showing water-level contours of Upper Macungie

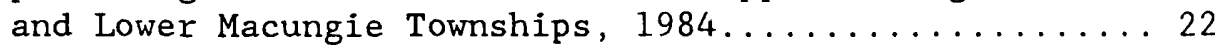

10. - Map showing location of streamflow-measurement sites in the Little Lehigh Creek basin............... 25

11.--Graph showing frequency distribution of streamflow, Little Lehigh and Jordan Creeks, 1967-86.......... 33

12.--Graph showing frequency distribution of base flow, Little Lehigh and Jordan Creeks, 1967-86..........33

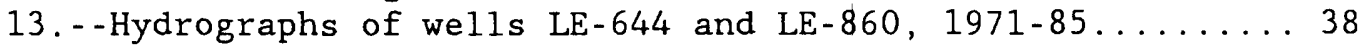

14.--Graph showing average daily discharge of Schantz and Crystal Springs and annual precipitation at

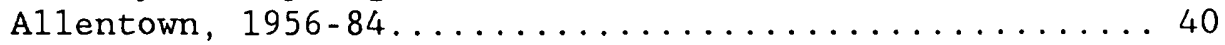

15.--Graph showing double-mass curve of the flow of Schantz Spring as a function of precipitation at

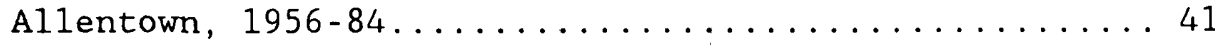

16. - Map showing water-level contours of Upper Macungie and Lower Macungie Townships, 1968.............44

17. - - Map showing model grid and boundary conditions........ 47

18. - Map showing location of stream cells.............. 50

19.--Graph showing annual ground-water pumpage, 1975-83..... 54

20. - Map showing simulated water-table surface in the Little Lehigh Creek basin. 
Figures 21-25.--Graphs showing:

21.--Effect of varying the value of model variables on base flow........................61

22.--Effect of varying the head in the source bed supplying water to head-dependent boundary nodes on base flow.....................62 62

23. --Effect of varying the value of model variables on the root mean squared error between observed and simulated head.................... 62

24.--Effect of varying the head in the source bed supplying water to head-dependent boundary nodes on the root mean squared error between observed and simulated head.................... 63

25. - - Frequency distribution of base flow of Little Lehigh Creek near Allentown, 1946-86.........664

26.--Map showing locations of hypothetical well fields to simulate increased ground-water development.... 66

\section{TABLES}

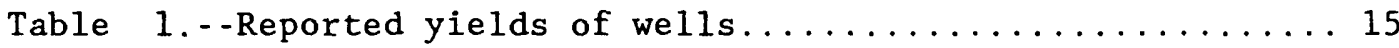

2. - -Reported specific capacity of wells........... 15

3. - -Number of water-bearing zones per 100 feet of uncased borehole drilled in carbonate rock....... 19

4.--Base flow of Little Lehigh Creek near

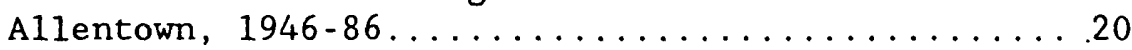

5.--Discharge measured during seepage investigation of Little Lehigh Creek, May $1,1985 \ldots \ldots \ldots \ldots \ldots 28$

6.--Discharge measured during seepage investigation of Little Lehigh Creek, December 4, 1985........ 29

7.--Discharge and water temperature measured during seepage investigation of Little Lehigh Creek,

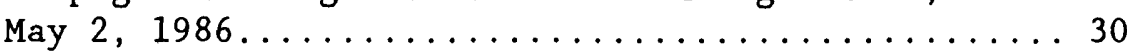

8.--Discharge and water temperature measured during seepage investigation of Cedar Creek, September $11,1986 \ldots \ldots \ldots \ldots \ldots \ldots \ldots \ldots \ldots \ldots$

9. - Average streamflow and base flow of Little Lehigh and Jordan Creeks, 1967-86.............. 32

10.--Water budgets for the Little Lehigh Creek basin,

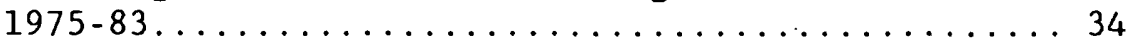

11. - Estimates of specific yield for the Little Lehigh Creek basin...................... 35

12. --Recharge to the Little Lehigh Creek basin, 1975-83... 36

13. - Aquifer hydraulic conductivity used for steadystate simulations.................. 52

14.-. Pumping rates used for model simulations......... 55

15. - Simulated average water budget for the Little Lehigh Creek basin and simulated spring discharge......................... 57 
Table 16.--Simulated changes in base flow and underflow caused by increased ground-water development for average conditions in the Little Lehigh

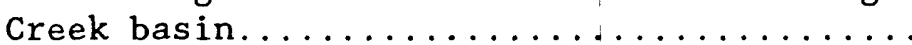

17. - Simulated changes in base flow and underflow caused by increased ground-water development for drought conditions in the Little Lehigh Creek basin........................6 69

18.--Records of selected wells and springs.........79 


\section{CONVERSION FACTORS AND ABBREVIATIONS}

\section{Multiply}

inch (in.)

inches per year (in/yr)

foot ( $f t)$

foot per day ( $f t / d)$

square foot per day $\left(f t^{2} / d\right)$

mile (mi)

square mile $\left(\mathrm{mi}^{2}\right)$

gallon (gal)

million gallons (Mgal)

gallon per minute

(gal/min)

gallon per minute per foot $[(\mathrm{gal} / \mathrm{min}) / \mathrm{ft}]$

gallon per day (gal/d)

million gallons per day

(Mgal/d)

cubic foot $\left(\mathrm{ft}^{3}\right)$

cubic foot per second $\left(\mathrm{ft}^{3} / \mathrm{s}\right)$

cubic foot per square mile $\left(\mathrm{ft}^{3} / \mathrm{mi}^{2}\right)$

degree Fahrenheit $\left({ }^{\circ} \mathrm{F}\right)$
By

To obtain

Length

25.4

25.4

0.3048

0.3048

0.09290

1.609

Area

2.590

Volume

3,785

3.785

0.06309

0.2070

0.00004381

0.04381

0.02832

0.02832

0.01093

Temperature

${ }^{\circ} \mathrm{C}=5 / 9 \quad\left({ }^{\circ} \mathrm{F}-32\right)$ square kilometer $\left(\mathrm{km}^{2}\right)$

millimeter (mm)

millimeters per year $(\mathrm{mm} / \mathrm{yr})$

meter ( $m$ )

meter per day $(\mathrm{m} / \mathrm{d})$

square meter per day $\left(\mathrm{m}^{2} / \mathrm{d}\right)$

kilometer $(\mathrm{km})$

liter (L)

cubic meter $\left(\mathrm{m}^{3}\right)$

liter per second $(\mathrm{L} / \mathrm{s})$

liter per second per meter $[(\mathrm{L} / \mathrm{s}) / \mathrm{m}]$

liter per second (L/s)

cubic meter per second $\left(\mathrm{m}^{3} / \mathrm{s}\right)$

cubic meter $\left(\mathrm{m}^{3}\right)$

cubic meter per second $\left(\mathrm{m}^{3} / \mathrm{s}\right)$

cubic meter per square kilometer $\left(\mathrm{m}^{3} / \mathrm{km}^{2}\right)$

degree Celsius $\left({ }^{\circ} \mathrm{C}\right)$

Sea level: In this report "sea level" refers to the National Geodetic Vertical Datum of 1929 (NGVD of 1929)--a geodetic datum derived from a general adjustment of the first-order level nets of both the United States and Canada, formerly called "Sea Level Datum of 1929." 
HYDROGEOLOGY AND GROUND-WATER FLOW IN THE CARBONATE

ROCKS OF THE LITTLE LEHIGH CREEK BASIN,

LEHIGH COUNTY, PENNSYLVANIA

By Ronald A. Sloto, L. DeWayne Cecil, and Lisa A. Senior

\section{ABSTRACT}

The Little Lehigh Creek basin is underlain mainly by a complex assemblage of highly-deformed Cambrian and Ordovician carbonate rocks. The Leithsville Formation, Allentown Dolomite, Beekmantown Group, and Jacksonburg Limestone act as a single hydrologic unit. Ground water moves through fractures and other secondary openings and generally is under water-table conditions. Median annual ground-water discharge (base flow) to Little Lehigh Creek near Allentown (station 01451500) during 1946-86 was 12.97 inches or 82 percent of streamflow. Average annual recharge for 1975-83 was 21.75 inches. Groundwater and surface-water divides do not coincide in the basin. Ground-water underflow from the Little Lehigh Creek basin to the Cedar Creek basin in 1987 was 4 inches per year. A double-mass curve analysis of the relation of cumulative precipitation at Allentown to the flow of Schantz Spring for 1956-84 showed that cessation of quarry pumping and development of ground water for public supply in the Schantz Spring basin did not affect the flow of Schantz Spring.

Ground-water flow in the Little Lehigh Creek basin was simulated using a finite-difference, two-dimensional computer model. The geologic units in the modeled area were simulated as a single water-table aquifer. The 134-squaremile area of carbonate rocks between the Lehigh River and Sacony Creek was modeled to include the natural hydrologic boundaries of the ground-water-flow system. The ground-water-flow model was calibrated under steady-state conditions using 1975-83 average recharge, evapotranspiration, and pumping rates. Each geologic unit was assigned a different hydraulic conductivity. Initial aquifer hydraulic conductivity was estimated from specific-capacity data. The average (1975-83) water budget for the Little Lehigh Creek basin was simulated. The simulated base flow from the carbonate rocks of the Little Lehigh Creek basin above gaging station 01451500 is 11.85 inches per year. The simulated ground-water underflow from the Little Lehigh Creek basin to the Cedar Creek basin is 4.04 inches per year. For steady-state calibration, the root-mean-squared difference between observed and simulated heads was 21.19 feet.

The effects of increased ground-water development on base flow and underflow out of the Little Lehigh Creek basin for average and drought conditions were simulated by locating a hypothetical well field in different parts of the basin. Steady-state simulations were used to represent equilibrium conditions, which would be the maximum expected long-term effect. Increased ground-water development was simulated as hypothetical well fields pumping at the rate of 15,25 , and 45 million gallons per day in addition to existing ground-water withdrawals. Four hypothetical well fields were located near and away from Little Lehigh Creek in upstream and downstream areas. 
The effects of pumping a well field in different parts of the Little Lehigh Creek basin were compared. Pumping a well field located near the headwaters of Little Lehigh Creek and away from the stream would have greatest effect on inducing underflow from the Sacony Creek basin and the least effect on reducing base flow and underflow to the Cedar Creek basin. Pumping a well field located near the headwaters of Little Lehigh Creek near the stream would have less impact on inducing underflow from the Sacony Creek basin and a greater impact on reducing the base flow of Little Lehigh Creek because more of the pumpage would come from diverted base flow. Pumping a well field located in the downstream area of the Little Lehigh Creek bas in away from the stream would have the greatest effect on the underflow to the Cedar Creek basin. Pumping a well field located in the downstream area of the Little Lehigh Creek basin near the stream would have the greatest effect on reducing the base flow of Little Lehigh Creek. Model simulations show that groundwater withdrawals do not cause a proportional reduction in base flow. Under average conditions, ground-water withdrawals are equal to 48 to 70 percent of simulated base-flow reductions; under drought conditions, ground-water withdrawals are equal to 35 to 73 percent of simulated base-flow reductions.

The hydraulic effects of pumping largely depend on well location. In the Little Lehigh basin, surface-water and ground-water divides do not coincide, and ground-water development, especially near surface-water divides, can cause ground-water divides to shift and induce ground-water underflow from adjacent basins. Large-scale ground-water pumping in a basin may not produce expected reductions of base flow in that basin because of shifts in the ground-water divide; however, such shifts can reduce base flow in adjacent surface-water basins.

\section{INTRODUCTION}

The carbonate rocks of the Little Lehigh Creek basin are an important source of water for residents of the Little Lehigh Creek basin and the nearby city of Allentown. Population in the Allentown area is rapidly growing and the demand for ground water is increasing. The hydrogeology of the carbonate rocks of the Little Lehigh Creek basin is complex because of the variable hydraulic characteristics of the various lithologies, complex structural relations, and karst terrane. This investigation by the U.S. Geological Survey (USGS) was made in cooperation with the Delaware River Basin Commission, the Pennsylvania Department of Environmental Resources, the Lehigh County Authority, the City of Allentown, and South Whitehall Township. 
This report describes the ground-water-flow system in the carbonate rocks and the hydrologic budget of the Little Lehigh Creek basin. The report also describes the development and use of a steady-state finite-difference model to: (1) simulate ground-water flow in the carbonate-rock aquifer system, (2) simulate the hydrologic budget for the $80.8 \mathrm{mi}^{2}$ (square mile) area of the Little Lehigh Creek basin above streamflow-gaging station 01451500, and (3) estimate the effect of increased ground-water pumping on the hydrologic budget.

The area of primary interest is underlain by the carbonate rocks in the Little Lehigh Creek basin. However, a larger area is modeled to include necessary hydrologic boundaries. The modeled area includes carbonate rocks in the Little Lehigh Creek basin and part of the Sacony Creek basin in Lehigh and Berks Counties. The study area is bordered on the east by the Lehigh River, on the west by Sacony Creek, on the north by the Martinsburg Formation, and on the south by Hardyston Quartzite.

\section{Location and Physiography}

The Little Lehigh Creek basin is located in central Lehigh County in eastern Pennsylvania (fig. 1). The drainage area of the Little Lehigh Creek basin is $190 \mathrm{mi}^{2}$, of which nearly $81 \mathrm{mi}^{2}$ is underlain by carbonate rocks. The main tributaries to Little Lehigh Creek are Jordan Creek (drainage area 82.3 $\mathrm{mi}^{2}$ ) and Cedar Creek (drainage area $15.0 \mathrm{mi}^{2}$ ). The Little Lehigh Creek and its tributaries flow eastward, joining the Lehigh River near Allentown. On the western boundary, Sacony Creek drains to the Schuylkill River.

The Lehigh Valley is part of the Valley and Ridge physiographic province (fig. 2). The carbonate rocks that underlie the valley are the focus of this study. The Lehigh Valley is bordered on the north by ridge-forming noncarbonate rocks of the Martinsburg Formation. The Martinsburg Formation, together with carbonate-rock units, belong to the Lehigh Valley and Schuylkill Valley sequences. The Lehigh Valley is bordered to the south by the ridgeforming crystalline rocks of the Reading Prong section of the New England physiographic province. 


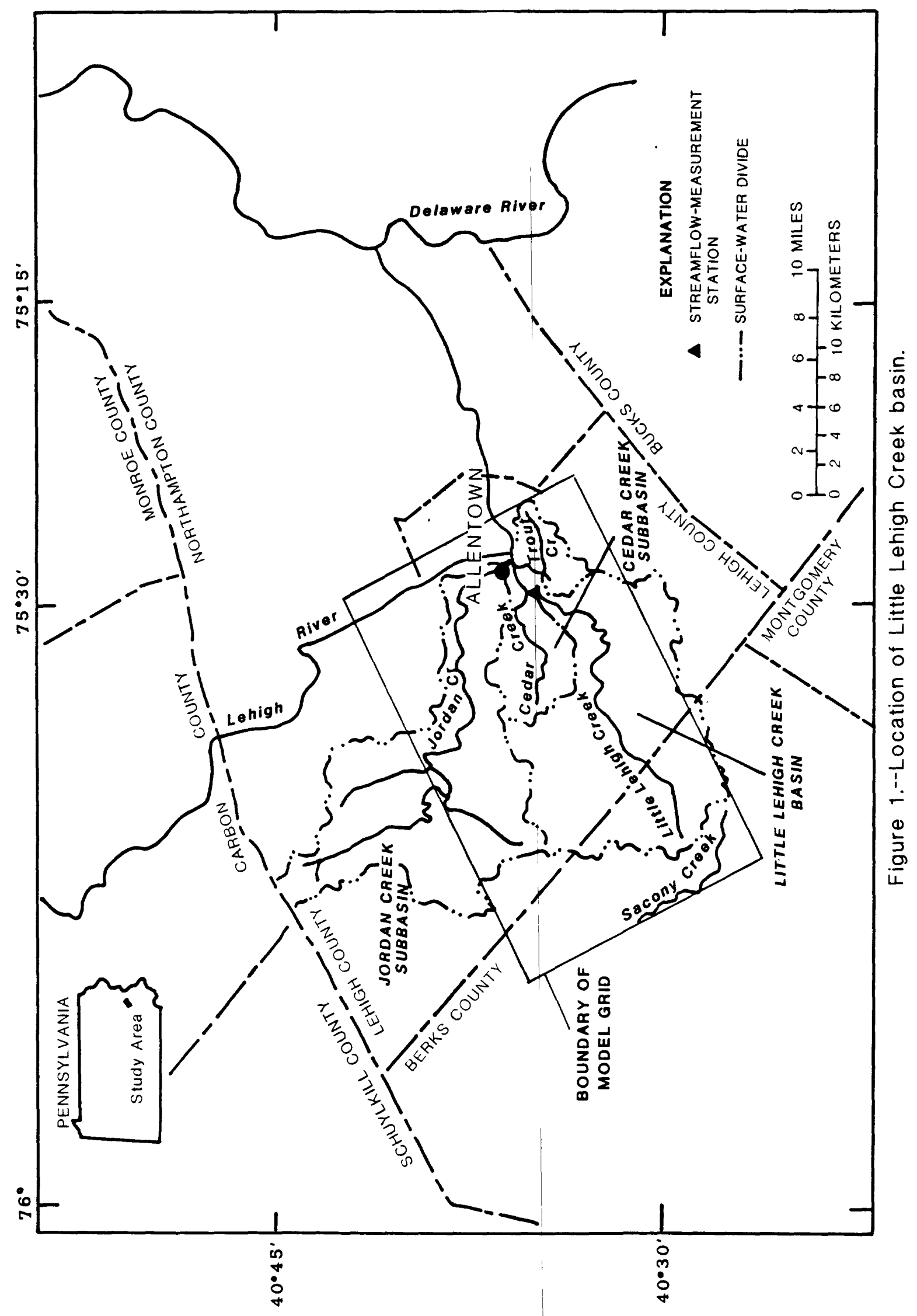




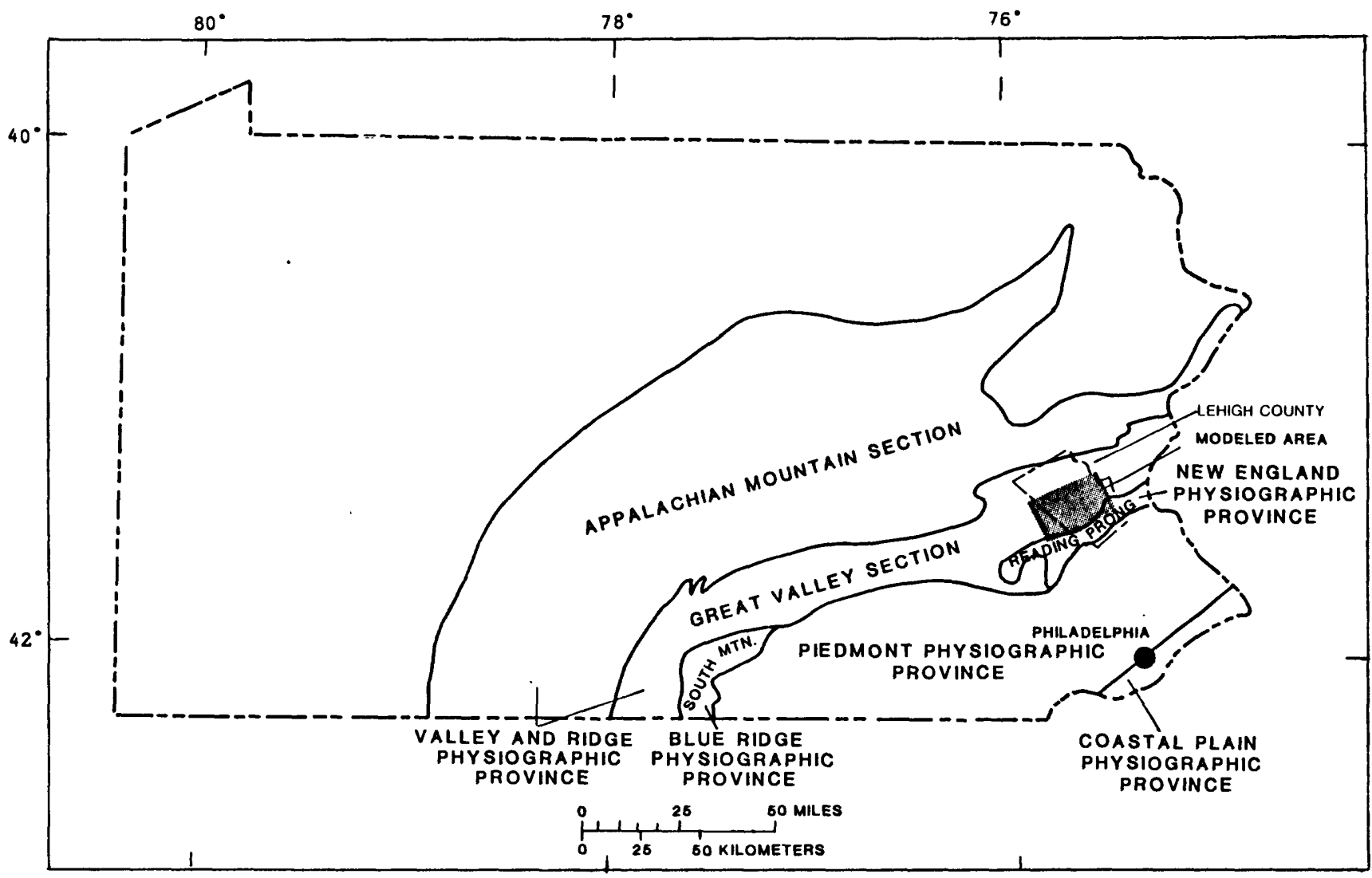

Figure 2.--Physiographic provinces.

Climate

The climate in the Lehigh Valley is temperate with relatively high humidity. Precipitation is nearly evenly distributed throughout the year, with slightly more in July and August than in other months. The 1951-80 normal precipitation at the Allentown-Bethlehem-Easton airport is $44.31 \mathrm{in} / \mathrm{yr}$ (inches per year) (National Oceanic and Atmospheric Administration, 1982). January is the coldest month; the 1951-80 average temperature for January is $27.3^{\circ} \mathrm{F}$ (degrees Fahrenheit). July is the warmest month; the 1951-80 average temperature for July is 73.9 ${ }^{\circ} \mathrm{F}$. The 1951-80 average annual temperature at the Allentown-Bethlehem-Easton airport is $51.1^{\circ} \mathrm{F}$.

\section{We11-Numbering System}

The well-numbering system used in this report consists of two parts: (1) a two-letter abbreviation that identifies the county in which the well is located, and (2) a sequentially-assigned number. All wells are in Berks or Lehigh counties and are identified by the prefixes $B E$ and. LE, respectively. Locations of selected wells, with the prefixes BE and LE omitted from the local well number, are shown on plate 1 . The site-identification number given in table 18 has 15 digits. The first six digits denote the degrees, minutes, and seconds of latitude; the next seven digits denote the degrees, minutes, and seconds of longitude; and the last two digits denote a sequentiallyassigned number to distinguish among sites located within a common 1 -second grid block. 


\section{Previous Investigations}

Miller (1941) described the geology of Lehigh County and included a discussion of ground-water resources. Wood and others (1972) described the water-resources of Lehigh County in detail. Drake (1960, 1965, 1978, and 1987) interpreted the structure and stratigraphy of the area. Kochanov (1987) mapped sink holes and other karst features.

Well data used for analysis in this study are given by Wood and others (1972, p. 228-263) for Lehigh County and Wood and MacLachlan (1978, p. 61-91) for Berks County. Additional data are given in table 18 in this report.

\section{Acknowledgments}

The cooperation of well owners and local, county, and state officials is gratefully acknowledged, especially the Lehigh County Authority (LCA) and the City of Allentown, for providing essential data. Additional data were provided by the Stroh Brewery Company, Gannett Fleming Geotechnical Engineers Inc., and the Lane Hydro Group, Inc. 


\section{HYDROGEOLOGY}

The Little Lehigh Creek basin is underlain by highly-deformed Paleozoic carbonate rocks and is bordered by Paleozoic and older noncarbonate rocks that are more resistant to erosion. Both lithology and structure determine the geologic boundaries separating the carbonate and noncarbonate rocks. The Precambrian crystalline rocks of the Reading Prong and a Cambrian quartzite and other sediments are south of the northeast trending carbonate valley (fig. 2). Two series of deformed Paleozoic slates, shales, mudstones, and graywackes are north of the carbonate valley. The noncarbonate rocks to the north and south form geologic and hydrologic boundaries to the Lehigh Valley. Generally, ground-water and surface-water basin divides to the north and south of the Lehigh Valley coincide with ridge crests of the bordering noncarbonate rocks. Water enters the carbonate valley as precipitation and ground-water and surface-water flow from the flanking noncarbonate rocks.

\section{$\underline{\text { Geology }}$}

The Little Lehigh Creek basin is underlain by a structurally-complex assemblage of Paleozoic carbonate and noncarbonate rocks (pl. 1). Several distinct sequences of rocks were emplaced as nappes, which are large overturned folds or major thrust slices. Due in part to the structural displacement of the rock sequences, stratigraphic relations change from east to west. The general stratigraphy is shown in figure 3 . The oldest rocks are the Precambrian crystalline rocks of the Reading Prong that form the south flank of the valley. The youngest rocks are the shales, mudstones, and graywackes of the Middle Ordovician Martinsburg Formation that form the north flank of the valley. Other younger, unconsolidated material, such as till and drift deposited during Illinoian glaciation, partly covers the carbonate rocks of Lehigh Valley and the bordering northern noncarbonate rocks. General geology, mapping, and description of geologic units and structure has been compiled for this report from many sources (Drake, 1960, 1965, 1978, and 1987; Lash, 1985; Miller, 1941; Poth, 1972; Wood and others, 1972; MacLachlan, 1979 and 1983; MacLachlan and others, 1975; Berg and Dodge, 1981; Berg and others, 1986; Lyttle and Epstein, 1987; Hobson, 1963; Kochanov, 1987).

\section{Stratigraphy of the Carbonate Rocks}

The carbonate rocks of the Little Lehigh Creek basin lie within the eastern end of the Great Valley section of the Valley and Ridge physiographic province (fig. 2) and have been divided into two related stratigraphic sequences by MacLachlan $(1967,1983)$. The Schuylkill Valley sequence crops out in the southwestern part of the Little Lehigh Creek basin and is separated from the Lehigh Valley sequence by the Black River thrust fault. The Schuylkill Valley sequence is similar to the Lehigh Valley sequence, but differs from it by the presence of the Stonehenge Limestone and the Ontelaunee Formation, the absence of the Jacksonburg cement rock facies of the Jacksonburg Limestone, and the occurrence of limestone and magnesium limestone in the Tuckerton Member of the Allentown Dolomite. Generally, the ages of the carbonate rocks exposed in the Lehigh Valley are progressively younger from south to north, and where not structurally dislocated, represent a continuous stratigraphic sequence from Lower Cambrian to Middle Ordovician. 


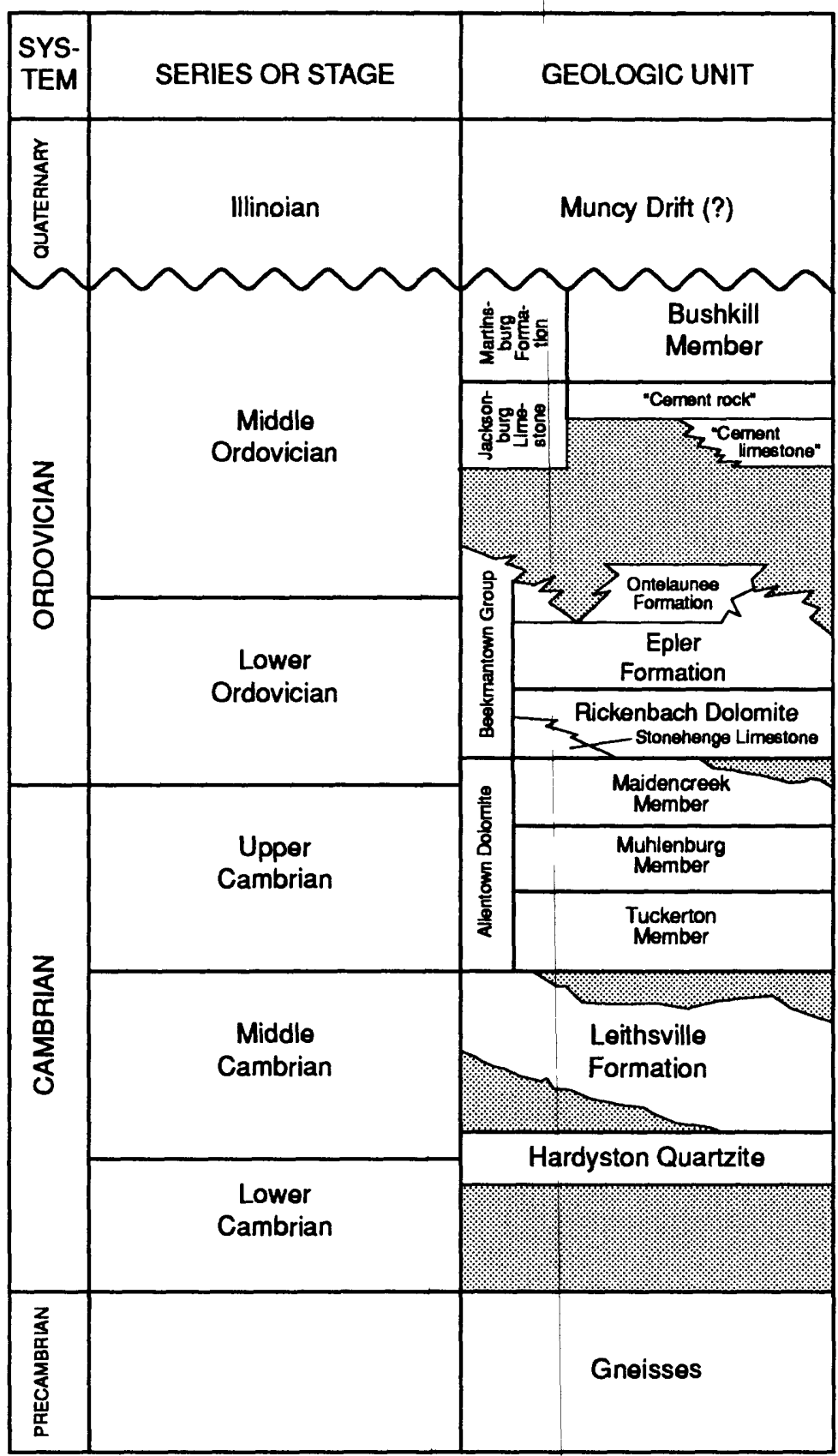

Figure 3.--Generalized stratigraphic column for Schuylkill and Lehigh Valley sequences. (Modified from Lash and Drake 1985, and Lyttle and Epstien 1987 ).

\section{Leithsville Formation}

The Lower to Middle Cambrian Leithsville Formation is the oldest carbonate unit exposed in the study area and is conformable or in fault contact with the underlying Lower Cambrian Hardyston Quartzite. The Leithsville Formation is a medium to dark-medium gray, thick-bedded, finelycrystalline dolomite with shaly beds in the upper part. The formation is about $400 \mathrm{ft}$ (feet) thick. 


\section{Allentown Dolomite}

The Upper Cambrian and Lower Ordovician Allentown Dolomite has three members: the Tuckerton (lower), Muhlenberg (middle), and Maidencreek (upper). Total thickness of the Allentown Dolomite is about 2,500 ft. The Tuckerton Member is a light to dark-medium gray, medium- to thick-bedded dolomite. In the Schuylkill Valley sequence, it contains magnesium limestone and limestone with limey beds having silty or shaly partings. The Tuckerton Member is 500 to $650 \mathrm{ft}$ thick. The Muhlenberg Member is a medium gray, thick-bedded dolomite and magnesium 1 imestone containing interbedded calcareous and limonitic sandstone. The Muhlenberg Member is about $800 \mathrm{ft}$ thick. The Maidencreek Member is a medium to dark-medium gray, thick-bedded dolomite and magnesium limestone containing chert stringers and nodules. The Maidencreek Member is about 1,200 ft thick.

\section{Beekmantown Group}

The Beekmantown Group includes four units in ascending order: the Stonehenge Limestone, the Rickenbach Dolomite, the Epler Formation, and the Ontelaunee Formation. Total thickness of the Beekmantown Group is about $2,100 \mathrm{ft}$. The Lower Ordovician Stonehenge Limestone is a medium gray, mediumto thick-bedded, finely-crystalline limestone with silty or sandy laminae, sporadic beds, lenses of fossil hash, and intraformational conglomerate. It has dolomite beds near the base. The Stonehenge Limestone is about $400 \mathrm{ft}$ thick. The Lower Ordovician Rickenbach Dolomite is a medium to dark-medium gray, medium- to coarsely-crystalline dolomite containing chert rosettes and gray, finely-crystalline dolomite with chert nodules, lenses, and beds. The Rickenbach Dolomite is about $500 \mathrm{ft}$ thick. The Lower Ordovician Epler Formation is a medium to dark-medium gray, finely-crystalline, silty limestone interbedded with some thin- to thick-bedded cryptocrystalline dolomite. The Epler Formation is about $650 \mathrm{ft}$ thick. The Lower to Middle Ordovician Ontelaunee Formation is a medium to dark gray, medium- to thick-bedded, veryfinely- to finely-crystalline limestone with some medium-bedded, mediumcrystalline dolomite. It has dark gray chert beds and nodules near the base. Thickness of the Ontelaunee Formation is about $500 \mathrm{ft}$. Its upper contact is a fault.

\section{Jacksonburg Limestone}

The Middle Ordovician Jacksonburg Limestone of the Lehigh Valley sequence differs from the Jacksonburg Limestone of the Schuylkill Valley sequence by the presence of cement limestone. The Jacksonburg Limestone of the Lehigh Valley sequence is divided into a cement limestone and cement rock facies. The cement limestone facies is a light to medium gray, medium- to coarsegrained calcarenite and fine- to medium-crystalline high-calcium limestone. The lower contact with the Beekmantown Group is a fault in most places. The cement limestone facies is about $350 \mathrm{ft}$ thick. The cement-rock facies is dark gray to black, fine- to medium-grained limestone with scattered, thin beds of crystalline limestone; bedding commonly is obliterated by slaty cleavage. The cement rock facies is about $400 \mathrm{ft}$ thick. The upper contact of the unit is a fault in places. 
The Jacksonburg Limestone, undivided, of the Schuylkill Valley sequence is a dark gray to black, laminated to medium-bedded, fine-grained argillaceous limestone with some crystalline limestone and caicareous limestone beds. Lower and upper contacts are mostly faults, but, in places, the Jacksonburg Limestone disconformably overlies the Ontelaunee Formation.

\section{Stratigraphy of the Noncarbonate Rocks}

The oldest noncarbonate rocks, the Precambrian crystalline rocks of the Reading Prong and the Lower Cambrian Hardyston Quartzite, form the southern boundary of the Lehigh Valley. The Reading Prong is comprised of a structurally-complex series of metamorphosed gneisses of different compositions and is the detached core of a recumbent nappe. Hardyston Quartzite unconformably overlies the gneiss. It is light gray, medium- to thick-bedded quartzite and feldspathic sandstone with a basal quartz-pebble conglomerate. The Hardyston Quartzite ranges from 100 to more than $800 \mathrm{ft}$ thick.

The noncarbonate rocks forming the northern border of the Lehigh Valley belong to several different stratigraphic sequences--the related Lehigh Valley and Schuylkill Valley sequences in the eastern and central section of the study area and the Hamburg klippe in the western section of the study area.

The Middle Ordovician Bushkill Member|of the Martinsburg Formation is stratigraphically above the Middle Ordovician Jacksonburg Limestone of the Schuylkill and Lehigh Valley sequences. The Bushkill Member is lithologically similar in both sequences and is a medium to dark gray slate containing some thin beds of quartzose slate, graywacke, siltstone, and carbonaceous slate. The Bushkill Member thickens westward from 2,800 to 4,000 ft.

To the west and south of the Martinsburg Formation, the noncarbonate rocks bordering the Lehigh Valley belong to the Lower and Middle Ordovician Windsor Township Formation of the Hamburg klippe, an allochthonous stratigraphic sequence. The Windsor Township Formation has several mapped members and consists of shales, mudstones, siltstones, and graywackes. The Windsor Township Formation is more than $990 \mathrm{ft}$ thick.

\section{Structure and Regional Setting}

Regional structure of the area is explained as a series of large overturned folds and major thrust slices (Drake, 1978 and 1987). The observed complex structures are a result of repeated deformation of the rock units. More than four episodes of folding and more than two episodes of faulting are recognized (Drake, 1987). Major deformation occurred during the Taconic. Orogeny in the Late Ordovician, and further deformation occurred in the Allegheny Orogeny in the Late Permian. Regionally, the strike of structures and geologic units is northeast, with folded beds, thrust faults, and thrust slices dipping to the south or southeast. Locally, structures may not follow this pattern because of multiple deformations, high-angle offset faults, and antiformal or synformal attitudes. 
Faults commonly separate geologic units in the Lehigh Valley. The Reading Prong units and overlying Hardyston Quartzite most commonly are in thrust fault contact with the Leithsville Formation, which is lowest in the carbonate sequence. North of this contact is the Black River thrust fault that brings the Schuylkill Valley sedimentary sequence over the Lehigh Valley sequence. Within each of these sequences, the Beekmantown Group is thrust north over the Jacksonburg Limestone, and both of the carbonate sequences are thrust north over the Bushkill Member of the Martinsburg Formation and the allochthonous Hamburg klippe. Cross-sections (fig. 4) of the structure in the western section of the modeled area show the Black River thrust fault and fault contacts between carbonate units and shales of the Martinsburg Formation. Complex structures include windows or fault-bound slices of formations belonging to a different stratigraphic sequence such as the Cherry Hill window (fig. 4), overturned folds and faults, and refolded folds and faults. 


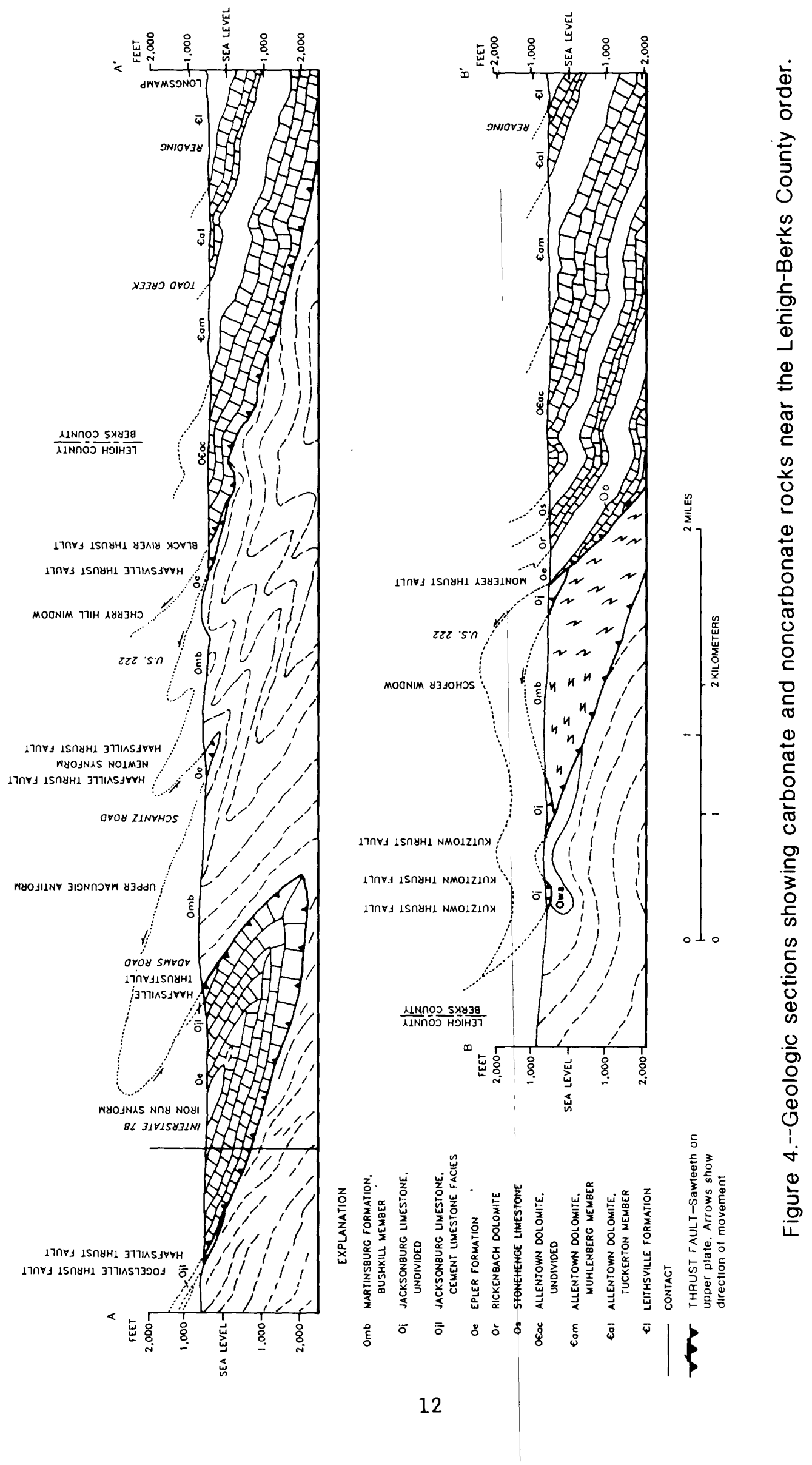




\section{Geomorphology}

Ongoing processes of physical and chemical weathering and past glacial processes are responsible for the reshaping of landforms following the major mountain-building events that occurred during the Paleozoic. Bordering the Lehigh Valley to the north, the shales, mudstones, and graywackes of the Martinsburg Formation and Hamburg klippe form ridges and steep-sided, hilly terrain. To the south of the Lehigh Valley, the Reading Prong complex forms rolling highlands. The carbonate rocks of the Lehigh Valley are more susceptible to erosion and form the gently rolling to nearly flat lowlands of the valley. The Jacksonburg Limestone cement rock is the most resistant to erosion of the carbonate rocks. Windows of rock units, such as the cherry Hill window (fig. 4), often expose rocks more or less resistant to erosion and create knobs or depressions in the valley terrain.

\section{Karst features}

Karst features, such as the numerous sinkholes in the Lehigh Valley, are caused by dissolution of the carbonate rocks (fig. 5). Closed depressions where surface water may accumulate are common. Dissolution enlarges fracture and fault openings that, in part, control some stream paths. These fractures and faults may be expressed at the surface as fracture traces. Sinkholes are fairly evenly distributed in the rocks of the Beekmantown Group and Allentown Dolomite, with about 40 percent of the total in each lithology. The Jacksonburg Limestone is the most resistant unit to sinkhole development. Sinkhole distribution was mapped by Kochanov (1987). Karst features can act as conduits for ground-water recharge and generally increase the permeability of bedrock aquifers.

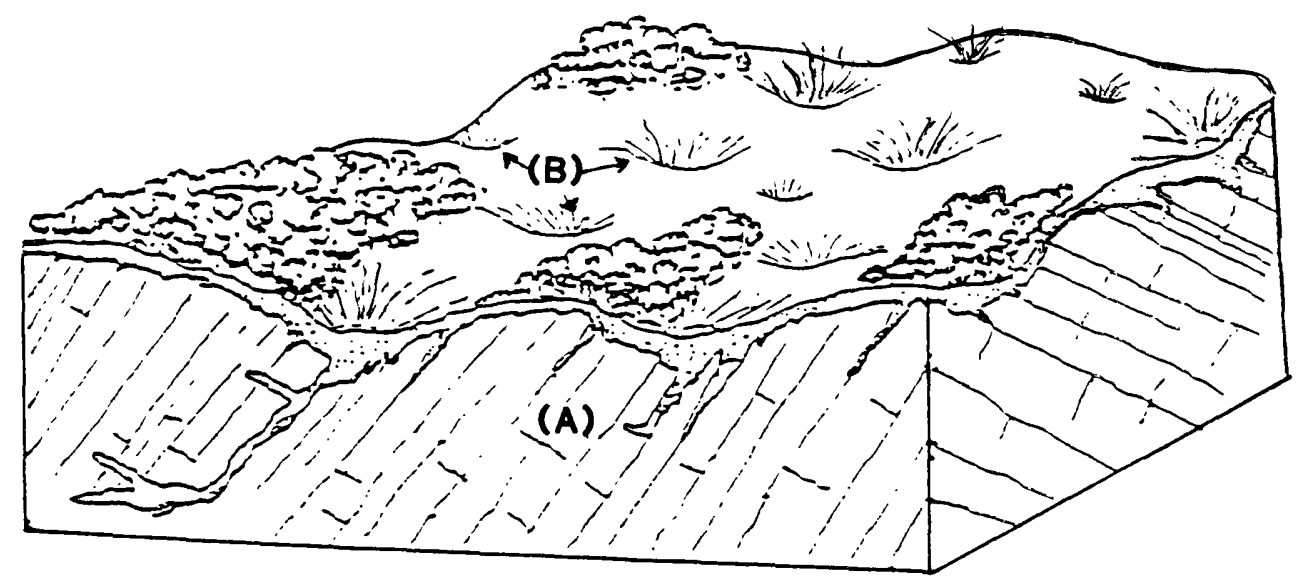

Figure 5.--Block diagram showing the relation between carbonate bedrock $(A)$ and surface topography in karst areas. Note closed basins (B). (From Kochanov, 1987.) 


\section{Glacial features}

Only deposits from the Illinoian glaciation extend as far south as the Lehigh Valley. The exact extent of Illinoian and possible pre-Illinoian ice is not known and has been delineated differently by various workers (Leverett, 1934; Poth, 1972; Epstein and others, 1974; Sevon and others, 1975; Braun, 1988). The extent of Illinoian glaciation described by Poth (1972) is shown in figure 6. From the Delaware River and the Blue Mountain Ridge, glacial deposits thin to the south and west toward the Lehigh Valley. Thickness of glacial deposits on the carbonate rocks in the eastern part of the study area range from a thin veneer to $120 \mathrm{ft}$ (Miller, 1941); the thickest accumulation is in stream valleys. Deposits tentatively are identified as Muncy drift. Glacial erratics and stratified clays have been observed in the study area (Miller, 1941; Myers and Perlow, 1984).

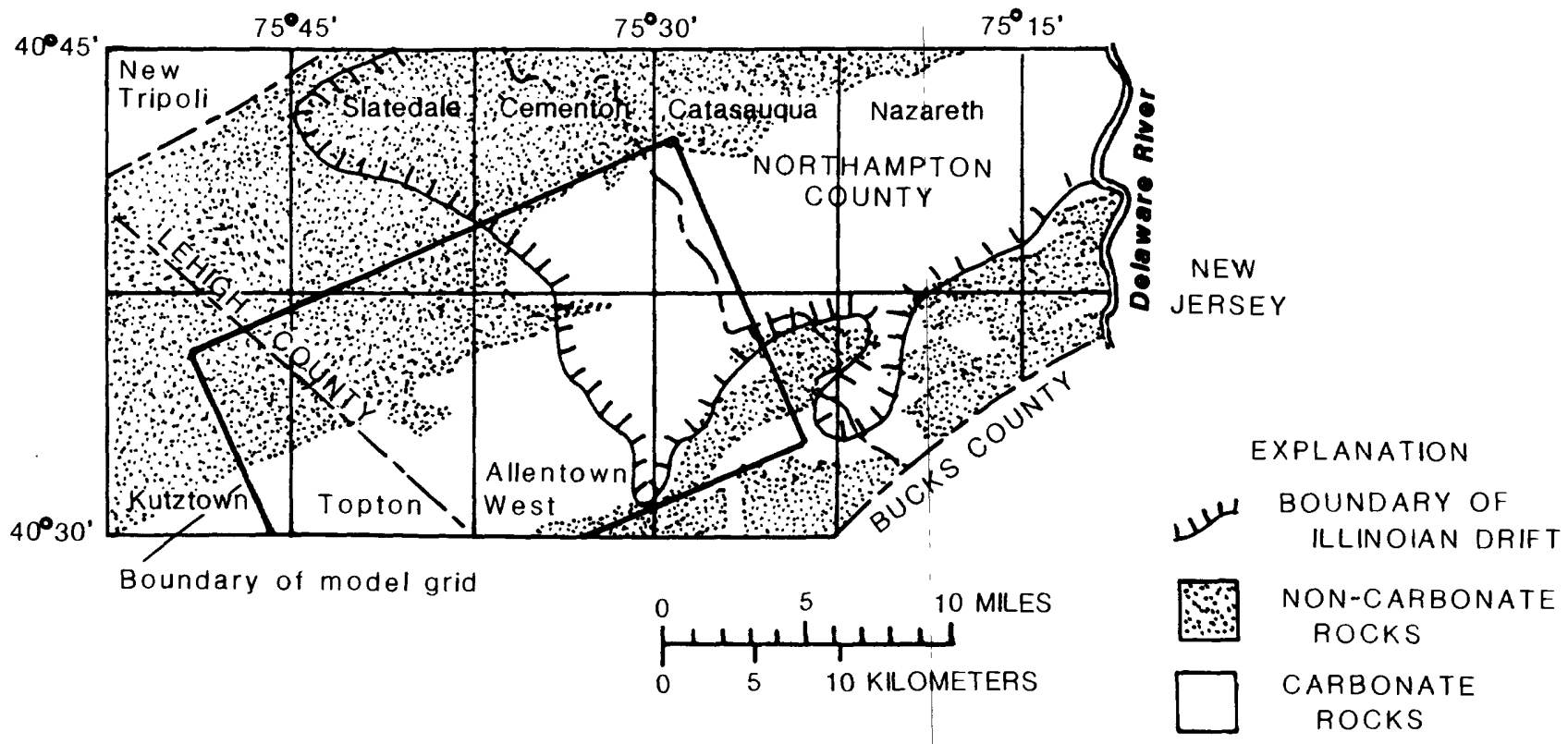

Figure 6.--Extent of Illinoian drift in Lehigh County. (From Poth 1972.)

\section{Hydrology}

In the Little Lehigh Creek basin, the Leithsville Formation, Allentown Dolomite, Beekmantown Group, and Jacksonburg Limestone act as a single hydrologic unit. Ground water moves through fractures and other secondary openings in these carbonate rocks. The carbonate aquifer system is generally under water-table conditions, but confined conditions exist locally.

A minor perched water-table aquifer in the glacial deposits exists locally in the central part of the study area. This aquifer is of limited areal extent; its presence is indicated by marshy and wet areas. The average saturated thickness of this system is about $30 \mathrm{ft}$. It is separated from the bedrock system by a low-permeability clay. In some places, stratified clay deposits are up to $10 \mathrm{ft}$ thick. 


\section{Hydraulic Characteristics of Carbonate Rocks}

Secondary porosity and permeability exhibit great spatial variation in carbonate rocks; therefore, the yield and specific capacity of wells are highly variable. Well yield depends on the number and size of openings penetrated below the water table--the more water-bearing openings intersected and the larger their size, the greater the well yield. The reported yield and specific capacity of wells in the modeled area are summarized in tables 1 and 2 , respectively.

The reported yield and specific capacity of nondomestic wells generally is an order of magnitude greater than the yield and specific capacity of domestic wells (tables 1 and 2). Nondomestic wells generally are drilled deeper, penetrate more water-bearing zones, and have larger diameters than domestic wells. Data from nondomestic wells give a better estimate of aquifer hydraulic characteristics than data from domestic wells.

\begin{tabular}{|c|c|c|c|c|c|c|c|c|c|}
\hline \multirow[b]{2}{*}{$\begin{array}{l}\text { Geologic } \\
\text { unit }\end{array}$} & \multicolumn{3}{|c|}{ Al1 wells } & \multicolumn{3}{|c|}{ Nondomestic wells } & \multicolumn{3}{|c|}{ Domestic wells } \\
\hline & $\begin{array}{l}\text { Number } \\
\text { of } \\
\text { wells }\end{array}$ & Range $M$ & Median & $\begin{array}{l}\text { Numbe } \\
\text { of } \\
\text { wells }\end{array}$ & s Range & Median & $\begin{array}{l}\text { Number } \\
\text { of } \\
\text { wells }\end{array}$ & Range & Median \\
\hline $\begin{array}{r}\text { Martinsburg } \\
\text { Formation }\end{array}$ & 42 & $1-\quad 100$ & 13 & 5 & $25-\quad 100$ & 25 & 37 & $1-$ & 10 \\
\hline $\begin{array}{r}\text { Jacksonburg } \\
\text { Limestone }\end{array}$ & 41 & $1-1,200$ & 20 & 9 & $8-1,200$ & 75 & 32 & $1-\quad 200$ & 17 \\
\hline $\begin{array}{l}\text { Beekmantown } \\
\text { Group }\end{array}$ & 79 & $<1-2,000$ & 35 & 27 & $10-2,000$ & 150 & 52 & $<1-500$ & 17 \\
\hline $\begin{array}{l}\text { A1lentown } \\
\text { Dolomite }\end{array}$ & 122 & $5-1,500$ & 55 & 36 & $17-1,460$ & 150 & 86 & $5-1,500$ & 30 \\
\hline $\begin{array}{r}\text { Leithsville } \\
\text { Formation }\end{array}$ & 56 & $2-1,000$ & 53 & 18 & $19-850$ & 250 & 38 & $2-1,000$ & 25 \\
\hline $\begin{array}{l}\text { Hardyston } \\
\text { Quartzite }\end{array}$ & 23 & $1-530$ & 35 & 10 & $14-530$ & 88 & 13 & $1-\quad 150$ & 15 \\
\hline & Tabl & $\begin{aligned} 1 \text { 2. } & - \text { - } \\
& \text { [Spp } \\
& \text { per } \\
& <\end{aligned}$ & $\begin{array}{l}\text { ported } \\
\text { pecific } \\
\text { r minut } \\
\text { less t }\end{array}$ & $\begin{array}{l}\text { specif } \\
\text { capac } \\
\text { e per } \\
\text { han; - }\end{array}$ & $\begin{array}{l}\text { fic capaci } \\
\text { city is in } \\
\text { foot of } \\
-, \text { no dat }\end{array}$ & $\begin{array}{l}\text { ity of } \\
\text { n gallon } \\
\text { drawdown } \\
\text { ta] }\end{array}$ & $\begin{array}{l}\text { ells } \\
\text { is } \\
\text {; }\end{array}$ & & \\
\hline $\begin{array}{l}\text { Geologic } \\
\text { unit }\end{array}$ & $\begin{array}{l}\text { Number } \\
\text { of } \\
\text { wells }\end{array}$ & $\begin{array}{l}\text { All wells } \\
\text { Range }\end{array}$ & Median & $\begin{array}{l}\frac{\text { Non }}{\text { Numbe }} \\
\text { of } \\
\text { wells }\end{array}$ & $\begin{array}{l}\text { ndomestic } \\
\text { er } \\
\text { s Range }\end{array}$ & wells & $\begin{array}{l}\frac{\text { Dome }}{\text { Number }} \\
\text { of } \\
\text { wells }\end{array}$ & $\begin{array}{l}\text { estic wel } \\
\text { Range }\end{array}$ & Median \\
\hline $\begin{array}{r}\text { Martinsburg } \\
\text { Formation }\end{array}$ & 14 & $0.04-13$ & 0.69 & 0 & -- & -- & 14 & $0.04-13$ & 0.69 \\
\hline $\begin{array}{r}\text { Jacksonburg } \\
\text { Limestone }\end{array}$ & 16 & $<.01-34$ & 1.2 & 5 & $0.27-34$ & 1.3 & 11 & $<.01-12$ & .29 \\
\hline $\begin{array}{l}\text { Beekmantown } \\
\text { Group }\end{array}$ & 30 & $<.01-330$ & 9.8 & 18 & $.02-330$ & 25 & 12 & $<.01-125$ & 2.0 \\
\hline $\begin{array}{l}\text { Allentown } \\
\text { Dolomite }\end{array}$ & 48 & $.03-125$ & 4.3 & 23 & $.14-125$ & 8.3 & 25 & $.03-115$ & 2.1 \\
\hline $\begin{array}{l}\text { Leithsville } \\
\text { Formation }\end{array}$ & 28 & $.18-375$ & 2.4 & 10 & $2.2-175$ & 5.3 & 18 & $.18-375$ & 1.3 \\
\hline $\begin{array}{l}\text { Hardyston } \\
\text { Quartzite }\end{array}$ & 15 & $<.01-18$ & .60 & 8 & $.39-.18$ & 1.5 & 7 & $<.01-.77$ & .37 \\
\hline
\end{tabular}


Yields of 79 wells in the Beekmantown Group in the modeled area range from 0.5 to $2,000 \mathrm{gal} / \mathrm{min}$ (gallons per minute). Only one yield exceeds $1,000 \mathrm{gal} / \mathrm{min}$. The median yield of 27 nondamestic wells is $150 \mathrm{gal} / \mathrm{min}$. Wells in the Beekmantown Group have a higher median specific capacity than wells in other carbonate units. The specific capacities of 30 wells range from less than 0.01 to 330 (gal/min)/ft (gallons per minute per foot) of drawdown; the median specific capacity of 18 nondomestic wells is $25(\mathrm{gal} / \mathrm{min}) / \mathrm{ft}$.

Aquifer tests were conducted on two wells in the Epler Formation of the Beekmantown Group. A 70-hour aquifer test of we11 LE-1319 was conducted September 9-12, 1985, by a private contractor. The pumping rate ranged from 1,000 to $2,000 \mathrm{gal} / \mathrm{min}$ and averaged $1,900 \mathrm{gal} / \mathrm{min}$. Drawdown in $\mathrm{LE}-1319$ was $6 \mathrm{ft}$ after 70 hours. Drawdowns were measured in five observation wells. The transmissivity, based on analysis of the aquifer-test data by the Cooper-Jacob method (Lohman, 1979, p. 19-23), was 33,000 $\mathrm{ft}^{2} / \mathrm{d}$ (square feet per day).

A 74-hour aquifer test of we11 LE-1355 was conducted February 11-14, 1986 , by a private contractor. The pumping rate was $1,400 \mathrm{gal} / \mathrm{min}$. Drawdown in LE- 1355 was $24 \mathrm{ft}$ after 73 hours. Drawdowns were measured in eight observation wells. Transmissivity, based on analysis of the aquifer-test data by the Cooper-Jacob method, was $44,400 \mathrm{ft}^{2} / \mathrm{d}$.

Yields of 122 wells in the Allentown Dolomite in the modeled area range from 5 to $1,500 \mathrm{gal} / \mathrm{min}$. Only four yields exceed $600 \mathrm{gal} / \mathrm{min}$. The median yield of 36 nondomestic wells is $150 \mathrm{gal} / \mathrm{min}$. Specific capacities of 48 wells range from 0.03 to 125 (gal/min)/ft; the median specific capacity of 23 nondomestic wells is 8.3 (gal/min)/ft.

Specific capacities of wells on hilltops in the Allentown Dolomite are much lower than specific capacities of wells in valleys. Specific-capacity data for wells in Lehigh County analyzed by topographic position by Wood and others (1972, p. 117) showed that wells in valleys had a median specific capacity of 33 (gal/min)/ft, whereas wells on hilltops had a median specific capacity of 1.2 (gal/min)/ft. The rock underlying valleys tends to be more fractured and more transmissive than rock underlying hilltops.

Nondomestic wells in the Leithsville Formation have a greater median yield than nondomestic wells in the other carbonate-rock units. Yields of 56 wells in the Leithsville Formation in the modeled area range from 2 to $1,000 \mathrm{gal} / \mathrm{min}$; the median yield of 18 nondomestic wells is $250 \mathrm{gal} / \mathrm{min}$. Specific capacities of 28 wells range from 0.18 to 375 (gal/min)/ft; the median specific capacity of 10 nondomestic wells is 5.3 (gal/min)/ft.

The Jacksonburg Limestone is the lowest-yielding carbonate-rock unit in the modeled area. Yields of 41 wells in the Jacksonburg Limestone in the modeled area range from 1 to $1,200 \mathrm{gal} / \mathrm{min}$; however, only three yields exceed $200 \mathrm{gal} / \mathrm{min}$. The median yield of nine nondomestic wells is $75 \mathrm{gal} / \mathrm{min}$. Wells in the Jacksonburg Limestone have a lower median specific capacity than wells in the other carbonate units. Specific capacitiles of 16 wells range from less than 0.01 to 34 (gal/min)/ft; the median specific capacity of five nondomestic wells is 1.3 (gal/min)/ft. 
Hydraulic Characteristics of Noncarbonate Rocks

Noncarbonate rocks underlie ridges north and south of the carbonate rocks. The Bushkill Member of the Martinsburg Formation is north of the carbonate valley, and the Hardyston Quartzite is south of the carbonate .valley.

Water in the noncarbonate rocks moves through relatively narrow fractures, such as joints, bedding partings, and faults. Unlike those in the carbonate rocks, these fractures are not enlarged by solution, and the noncarbonate rocks have a much lower hydraulic conductivity than carbonate rocks. Generally, yields (table 1) and specific capacities (table 2) of wells in the noncarbonate rocks are much lower than the yields and specific capacities of wells in the carbonate rocks. Some wells drilled into the noncarbonate rocks, especially those near the contact with carbonate rocks, are drilled through the noncarbonate rocks and derive water from the more permeable underlying carbonate rocks.

In the noncarbonate rocks, local streams act as drains for the groundwater system. Ground-water flow is local, flow paths are short, and ground water discharges to nearby streams draining the noncarbonate rock. Some ground water flows from the noncarbonate rocks to adjacent carbonate rocks.

The noncarbonate rocks are not as permeable as the carbonate rocks. Wood and others (1972, p. 103-104) estimated that overland runoff to streams underlying only noncarbonate rock was about 35 percent, whereas overland runoff to streams underlying only carbonate rock was 10 percent.

The Bushkill Member of the Martinsburg Formation is an aquifer with very low yic.ld. The median specific capacity of 14 domestic wells drilled into the Bushkill Member is 0.69 ( $\mathrm{gal} / \mathrm{min}) / \mathrm{ft}$ (table 2), which is the lowest median specific capacity of any geologic unit in the Little Lehigh Creek basin. Specific-capacity data are not available for nondomestic wells. The median yield of five nondomestic wells drilled into the Bushkill Member is $25 \mathrm{gal} / \mathrm{min}$ (table 1), which is the lowest median yield of any geologic unit in the Little Lehigh Creek basin.

The median specific capacity of nondomestic wells drilled into the Hardyston Quartzite is higher than the median specific capacity of nondomestic wells drilled into the Jacksonburg Limestone, but lower than the median specific capacity of nondomestic wells drilled into the other carbonate units. The median specific capacity of nondomestic wells drilled into the Hardyston Quartzite is 1.5 (gal/min)/ft (table 2). The median yield of 10 nondomestic wells drilled into the Hardyston is $88 \mathrm{gal} / \mathrm{min}$ (table 1 ). 


\section{Water-Bearing Zones}

Primary porosity in the carbonate rocks of the Lehigh Valley is virtually nonexistent. Occasional lenses of sand and gravel in the Leithsville Formation or Allentown Dolomite contain primary openings that yield a small quantity of water to wells (Wood and others, 1972, p. 105). However, most ground water flows through a network of interconnected secondary openings-fractures, joints, faults, parting planes, and bedding planes. Some of these openings have been enlarged by solution. The number and size of the openings determines the secondary porosity of the rock; the degree of interconnection of the openings determines the secondary permeability. The high permeability of carbonate rock is predominantly the result of enlargement of secondary openings by solution. Where solution has been active, permeability can be high; elsewhere, the same unit can be nearly impermeable.

Most openings enlarged by solution are only a fraction of an inch wide, but they are capable of high yields. Driller's records indicate that no more than 5 percent of all wells drilled into carbonate rock in Lehigh County penetrate water-bearing openings larger than $1 \mathrm{ft}$, although water-bearing zones as wide as $15 \mathrm{ft}$ have been reported (Wood and others, 1972, p. 107).

Geophysical logs are used to identify fractures and water-bearing zones in fractured rock, in addition to providing other information. The caliper $\log$ of well LE-1319 (fig. 7) shows a 4-ft-wide fracture between 167 and $171 \mathrm{ft}$ below land surface. This water-bearing zone produces 2,000 gal/min. The temperature, short normal resistivity, and spontaneous potential logs also show this major water-bearing zone. The caliper log shows minor fractures at 143,162 , and $185 \mathrm{ft}$ below land surface.

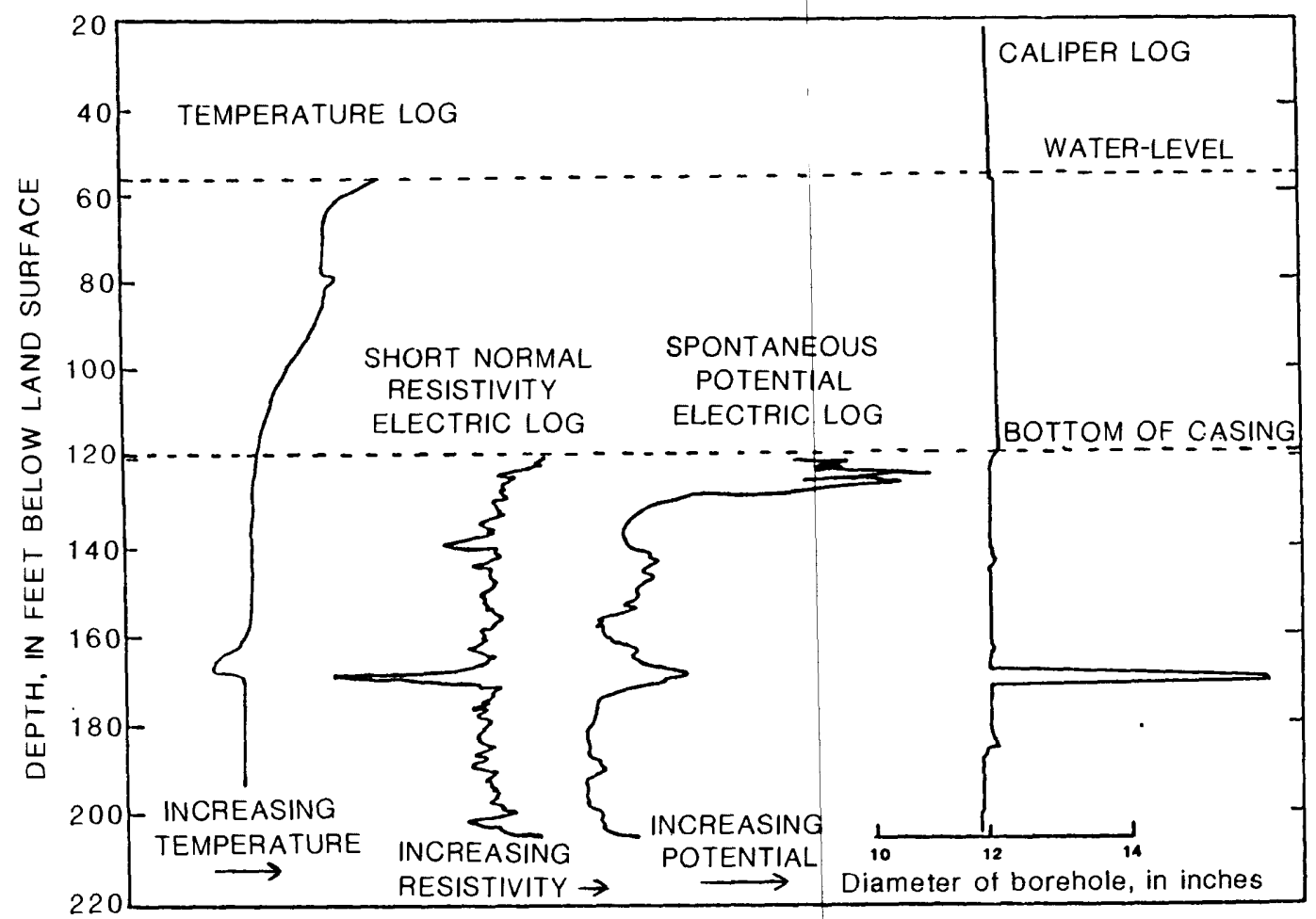

Figure 7.--Geophysical logs of well LE-1319. 
The frequency of occurrence of water-bearing zones decreases with depth. The distribution of 425 water-bearing zones in 191 wells in the Jacksonburg Limestone, Beekmantown Group, Allentown Dolomite, and Leithsville Formation in the modeled area was analyzed (table 3). These wells represent $27,228 \mathrm{ft}$ of uncased borehole, with well depths up to $907 \mathrm{ft}$. Fifty-one percent of the water-bearing zones are within $150 \mathrm{ft}$ of land surface, and 82 percent are within $250 \mathrm{ft}$ of 1 and surface. Only 4 percent of the water-bearing zones are below a depth of $350 \mathrm{ft}$. Table 3 shows that more than two water-bearing zones per $100 \mathrm{ft}$ of uncased borehole were encountered in the upper $100 \mathrm{ft}$, more than one water-bearing zone per $100 \mathrm{ft}$ in the upper $350 \mathrm{ft}$, and less than one water-bearing zone per $100 \mathrm{ft}$ below $350 \mathrm{ft}$. The large number of water-bearing zones per $100 \mathrm{ft}$ below a depth of $650 \mathrm{ft}$ is because of small sample size.

Table 3.--Number of water-bearing zones per 100 feet of uncased borehole drilled in carbonate rock

\begin{tabular}{cccc}
\hline $\begin{array}{c}\text { Depth } \\
\text { interval } \\
\text { (feet) }\end{array}$ & $\begin{array}{c}\text { Number of water- } \\
\text { bearing zones } \\
\text { penetrated }\end{array}$ & $\begin{array}{c}\text { Uncased foot- } \\
\text { age drilled } \\
\text { (feet) }\end{array}$ & $\begin{array}{c}\text { Number of water-bearing } \\
\text { zones per } 100 \text { feet of } \\
\text { uncased borehole }\end{array}$ \\
\hline $0-50$ & 44 & 1,177 & 3.74 \\
$51-100$ & 98 & 4,024 & 2.44 \\
$101-150$ & 75 & 5,349 & 1.40 \\
$151-200$ & 79 & 4,959 & 1.59 \\
$201-250$ & 51 & 3,542 & 1.44 \\
$251-300$ & 36 & 2,844 & 1.27 \\
$301-350$ & 23 & 1,743 & 1.32 \\
$351-400$ & 7 & 1,040 & .67 \\
$401-450$ & 2 & 675 & .30 \\
$451-500$ & 3 & 503 & .60 \\
$501-550$ & 2 & 382 & .52 \\
$551-600$ & 1 & 350 & .29 \\
$601-650$ & 1 & 300 & .33 \\
$651-700$ & 2 & 133 & 1.50 \\
Be10w 700 & 1 & 207 & $\mathrm{a}$ \\
& & & .48 \\
\hline
\end{tabular}

a Only one water-bearing zone was encountered in the interval 701-907

feet below land surface at 904 feet.

Ground-Water/Surface-Water Relations

The ground-water and surface-water systems are well connected in the Little Lehigh Creek basin. In the eastern part of the basin, ground water discharges to streams and comprises the base-flow component of streamflow. Ground-water discharge (base flow) made up 69 (in 1979) to 92 (in 1966) percent of the annual flow of Little Lehigh Creek at the streamflow-gaging station near Allentown (station 01451500) during 1946-86 (table 4). The median ground-water discharge was 82 percent of streamflow. Base-flow separations were made on hydrographs of Little Lehigh Creek using the computer program of Sloto (1991). The local minimum hydrograph-separation technique was used. The average annual base flow of Little Lehigh Creek ranged from $5.24 \mathrm{in.} \mathrm{(inches)} \mathrm{or} 31.2 \mathrm{ft}^{3} / \mathrm{s}$ (cubic feet per second) in 1965 to $21.74 \mathrm{in}$. or $129 \mathrm{ft}^{3} / \mathrm{s}$ in 1984 ; the median base flow for $1946-86$ was 12.97 in. or 77.2 $\mathrm{ft}^{3} / \mathrm{s}$. Figure 8 shows streamflow and base-flow hydrographs of Little Lehigh Creek for 1965, the year of lowest base flow, and 1984, the year of greatest base flow. 
Table 4.--Base flow of Little Lehigh Creek near Allentown, 1946-86

\begin{tabular}{|c|c|c|}
\hline Year & $\begin{array}{l}\text { Base flow } \\
\text { (inches) }\end{array}$ & $\begin{array}{c}\text { Percentage of } \\
\text { streamflow as } \\
\text { base flow }\end{array}$ \\
\hline 1946 & 15.27 & 87.4 \\
\hline 1947 & 13.01 & 87.6 \\
\hline 1948 & 16.10 & 83.9 \\
\hline 1949 & 14.36 & 88.9 \\
\hline 1950 & 11.75 & 88.0 \\
\hline 1951 & 17.19 & 85.3 \\
\hline 1952 & 21.39 & 79.9 \\
\hline 1953 & 21.15 & 83.5 \\
\hline 1954 & 10.16 & 83.7 \\
\hline 1955 & 12.68 & 80.2 \\
\hline 1956 & 12.97 & 83.9 \\
\hline 1957 & 10.00 & 81.2 \\
\hline 1958 & 13.10 & 75.7 \\
\hline 1959 & 8.93 & 80.4 \\
\hline 1960 & 11.95 & 84.5 \\
\hline 1961 & 11.02 & 86.8 \\
\hline 1962 & 9.50 & 77.3 \\
\hline 1963 & 8.26 & 80.6 \\
\hline 1964 & 7.87 & 84.2 \\
\hline 1965 & 5.24 & 87.5 \\
\hline 1966 & 5.42 & 91.9. \\
\hline 1967 & 8.30 & 84.5 \\
\hline 1968 & 9.74 & 84.4 \\
\hline 1969 & 7.64 & 79.8 \\
\hline 1970 & 10.71 & 82.4 \\
\hline 1971 & 17.99 & .77 .2 \\
\hline 1972 & 21.07 & 76.8 \\
\hline 1973 & 21.63 & 81.8 \\
\hline 1974 & 17.89 & 85.4 \\
\hline 1975 & 21.50 & 80.7 \\
\hline 1976 & 15.05 & 79.8 \\
\hline 1977 & 15.08 & 78.6 \\
\hline 1978 & 17.81 & 76.9 \\
\hline 1979 & 18.15 & 68.6 \\
\hline 1980 & 12.21 & 88.4 \\
\hline 1981 & 6.76 & 87.2 \\
\hline 1982 & 10.78 & 78.6 \\
\hline 1983 & 15.71 & 71.2 \\
\hline 1984 & 21.74 & 71.4 \\
\hline 1985 & 9.66 & 77.0 \\
\hline 1986 & 14.61 & 77.2 \\
\hline Median & 12.97 & 81.8 \\
\hline
\end{tabular}



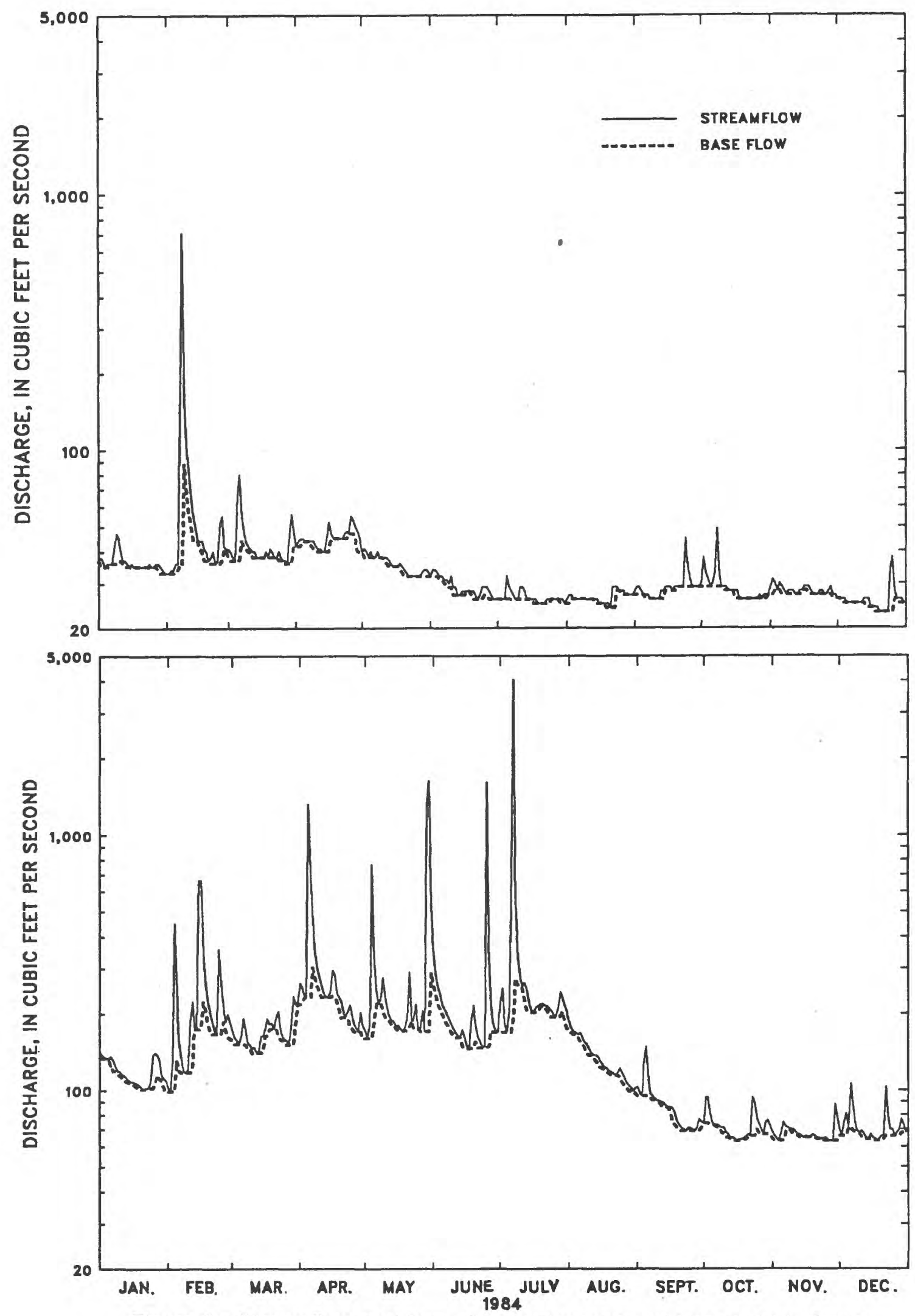

Figure 8.--Streamflow and base-flow hydrographs of Little Lehigh Creek near Allentown, 1965 and 1984. 


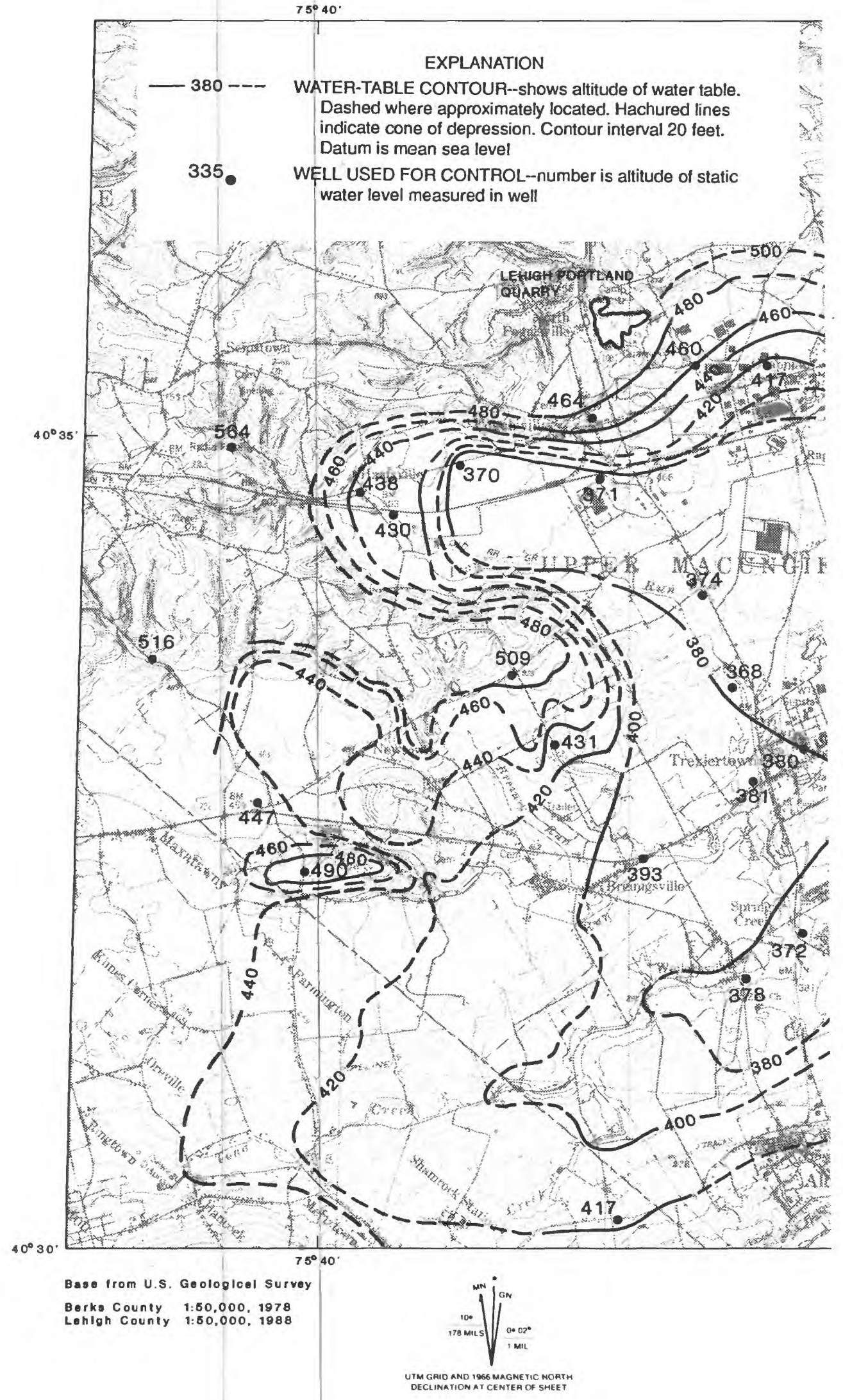




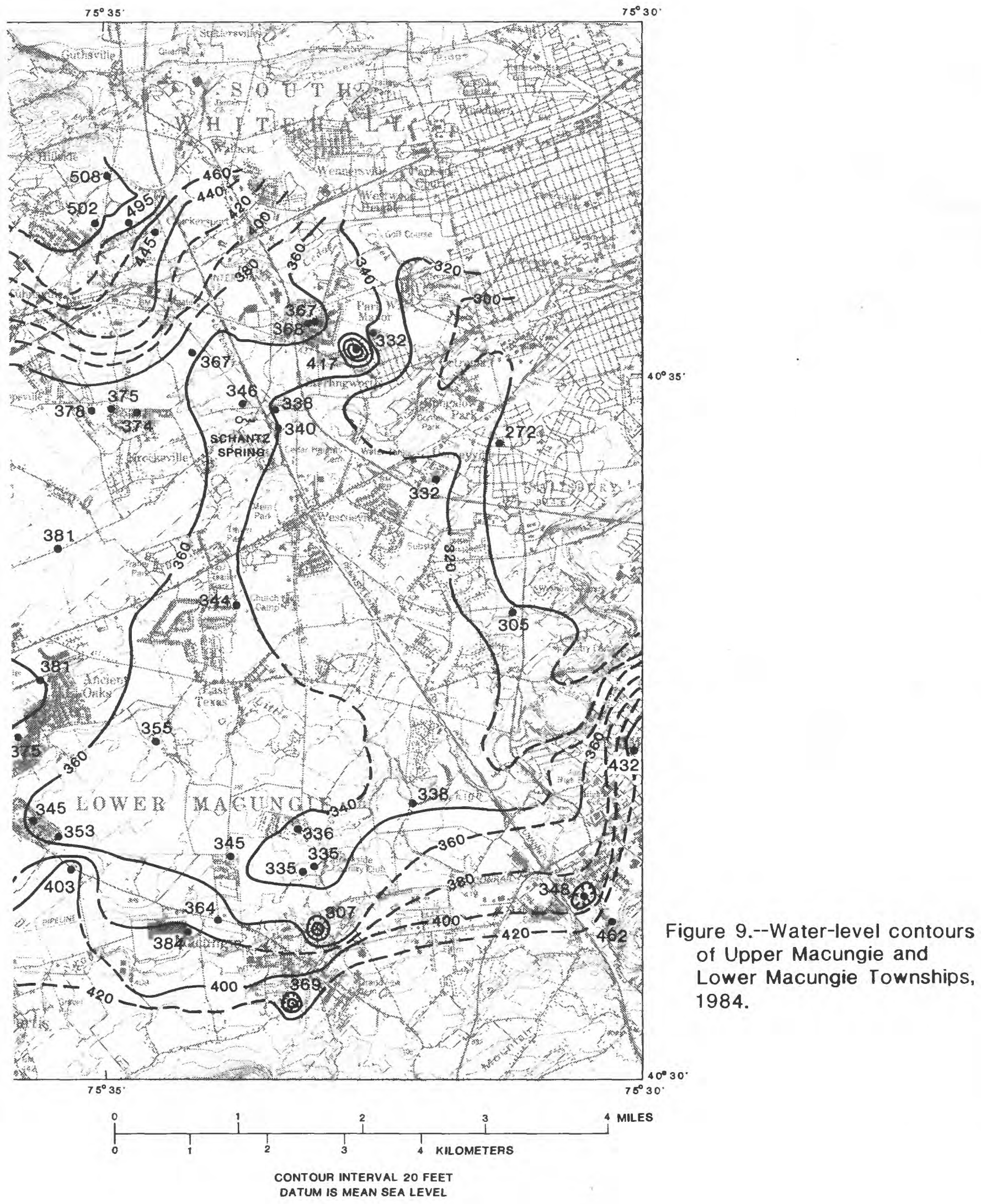


Ground-water divides and surface-watẹ divides do not coincide in the carbonate rocks of the Little Lehigh Creek basin. Wood and others (1972, p. 20 ) estimated from the location of ground-water divides on the 1968 watertable map that the ground-water basin contributing most of the streamflow measured at the streamflow gage on Little Lehigh Creek near Allentown (station 01451500 ) was $10.5 \mathrm{mi}^{2}$ smaller than the surface-water basin. Because groundwater divides and surface-water divides do not coincide, underflow of ground water occurs from the Little Lehigh Creek basin above the gaging station to adjoining surface-water basins.

Wood and others (1972, p. 20) estimated that ground water from $2.7 \mathrm{mi}^{2}$ of the Little Lehigh Creek surface-water basin above gaging station 01451500 flowed to the Lehigh Portland quarry because of the cone of depression caused by quarry dewatering. During the 1960's, the Lehigh Portland quarry, located near the boundary between the Little Lehigh and Jordan Creek basins, pumped as much as $4 \mathrm{Mgal} / \mathrm{d}$ (million gallons per day). The Lehigh Portland quarry has been inactive since 1970, and the 1984 water table map (fig. 9) does not show a cone of depression around the quarry. Thus, the Little Lehigh Creek groundwater basin is $2.7 \mathrm{mi}^{2}$ larger than it was in the $1960^{\prime} \mathrm{s}$.

Wood and others (1972, p. 21) estimated that $8.25 \mathrm{mi}^{2}$ of the $10.4 \mathrm{mi}^{2}$ Schantz Spring ground-water basin (as delineated by Wood and others, 1972, plate 1) underlies the Little Lehigh Creek surface-water basin above streamflow-gaging station 01451500, and underflow occurs from the Little Lehigh Creek surface-water basin to the Schantz Spring basin. Schantz Spring discharges to the Cedar Creek surface-water basin, and underflow from the Little Lehigh Creek basin increases the base flow of Cedar Creek. Wood and others (1972, p. 18) calculated that average underflow plus diversions from the Little Lehigh Creek surface-water basin above streamflow-gaging station 01451500 was $2.6 \mathrm{in} / \mathrm{yr}$ for 1946-62. The 1984 water-table map (fig. 9) shows that the ground-water divide between the Little Lehigh Creek and Schantz Spring ground-water basins is at nearly the same location as the divide on the 1968 water-table map (Wood and others, 1972, pls. 1 and 4A).

The installation of a new streamflow-gaging station in 1986 on Little Lehigh Creek just below the confluence with Cedar Creek permits an approximate calculation of underflow between the Little Lehigh Creek and Cedar Creek basins. The newer downstream gaging station, Little Lehigh Creek at 10th Street Bridge, Allentown (station number 01451650) and the older upstream gaging station, Little Lehigh Creek near Allentown (01451500) are shown on figure 10. Gaging station 01451500 measures the discharge from $80.8 \mathrm{mi}^{2}$ of the Little Lehigh Creek basin above the confluence with Cedar Creek. Gaging station 01451650 measures the discharge from $98.2 \mathrm{miz}$ of the Little Lehigh Creek basin. Subtracting the discharge at 01451500 from 01451650 gives the discharge from the entire $15 \mathrm{mi}^{2}$ Cedar Creek basin and $2.4 \mathrm{mi}^{2}$ of the Little Lehigh Creek basin below gaging station 01451500. The city of Allentown pumps water for public supply from Little Lehigh Creek above gaging station 01451650. Daily diversions by the city of Allentown were added to the mean daily discharge measured at gaging station 01451650 to create streamflow record without the diversion. The revised hydrograph was separated into base-flow and overland-runoff components using hydrograph-separation techniques (Sloto, 1991). The city of Allentown diverts most of the flow from Schantz. Spring that otherwise would discharge to Cedar Creek and most of the 





flow from Crystal Spring that otherwise would discharge to Little Lehigh Creek just above gaging station 01451650. The Schantz Spring and Crystal Spring diversions and ground-water withdrawals are added to the base flow estimated at gaging station 01451650 in order to calculate the total ground-water discharge from the Little Lehigh Creek basin above the gaging station 01451650 .

Assumptions for the underflow calculation are that recharge and groundwater discharge (base flow) are equal over the area of each basin and underflow only occurs between the Little Lehigh Creek basin above gaging station 01451500 and the Cedar Creek basin. The assumption of equal recharge and base flow is supported by similar physical characteristics (geology, topography, and precipitation) of each basin. The actual distribution of ground-water discharge over the basins is unknown. In reality, it probably varies both spatially and temporally. The assumption of no net underflow to other basins is supported by the 1984 water-table map, which shows a groundwater divide very near the western boundary of the Little Lehigh surface-water basin. Ground-water divides are coincident with surface-water divides in noncarbonate rocks to the north and south.

The total volume of ground-water discharge from the basin above gaging station 01451650 is calculated by

$$
\mathrm{V}_{t}=\mathrm{D}_{\mathrm{s}}+\mathrm{BF} \mathrm{t}_{\mathrm{t}}+\mathrm{GW}_{\mathrm{t}}
$$

where

$$
\begin{aligned}
\mathrm{V}_{\mathrm{t}}= & \text { total volume of ground-water discharge, } \\
\mathrm{D}_{\mathrm{s}}= & \text { diversions from Schantz and Crystal Springs, } \\
\mathrm{BF}_{\mathrm{t}}= & \text { estimated base flow at gaging station } 01451650 \text {, and } \\
\mathrm{GW}_{t}= & \begin{array}{l}
\text { ground-water withdrawals from the basin above gaging } \\
\text { station } 01451650 \text { exported from the basin. }
\end{array}
\end{aligned}
$$

For 1987 ,

$$
v_{t}=5.7 \times 10^{8} \mathrm{ft}^{3}+3.60 \times 10^{9} \mathrm{ft}^{3}+3.68 \times 10^{8} \mathrm{ft}^{3}=4.54 \times 10^{9} \mathrm{ft}^{3}
$$

The total volume of ground-water discharge $\left(V_{t}\right)$ is divided by the drainage area (DA ) at gaging station 01451650 to calculate the volume of ground-water discharge per square mile $\left(\mathrm{V}_{\mathrm{sm}}\right)$ :

$$
\mathrm{V}_{\mathrm{sm}}=\frac{\mathrm{V}_{t}}{\mathrm{DA}_{t}}=\frac{4.54 \times 10^{9} \mathrm{ft}^{3}}{98.2 \mathrm{mi}^{2}}=4.62 \times 10^{7} \mathrm{ft}^{3} / \mathrm{mi}^{2}
$$

Therefore, the volume of ground-water discharge per square mile ( $V_{\text {sm }}$ ) from Little Lehigh Creek basin above gaging station 01451650 sms $4.62 \times 10^{7} \mathrm{ft}^{3} / \mathrm{mi}^{2}$ (cubic feet per square mile). Assuming equal groundwater discharge to Little Lehigh Creek everywhere in the basin, the theoretical volume of ground-water discharge from the $80.8-\mathrm{mi}^{2}$ drainage area above gaging station $01451500\left(V_{1}\right)$ would be equal to the volume of groundwater discharge per square mile $\left(\mathrm{V}_{\mathrm{sm}}\right)$ multiplied by the drainage area of the basin above gaging station $01451500^{s m}\left(\mathrm{DA}_{1}\right)$ :

$$
V_{1}=V_{s m} \times D A_{1}=4.62 \times 10^{7} \mathrm{ft}^{3} / \mathrm{mi}^{2} \times 80.8 \mathrm{mi}^{2}=3.73 \times 10^{9} \mathrm{ft}^{3}
$$


The actual base flow from the $80.8-\mathrm{mi}^{2}$ basin above gaging station 01451500 $\left(B F_{1}\right)$ was estimated using hydrograph-separation techniques (Sloto, 1991). Underflow (U) is then calculated by subtracting the sum of the base flow plus ground-water withdrawals $\left(G_{1}\right)$ from the theoretical discharge to the basin $\left(\mathrm{V}_{1}\right)$ above gaging station 01451500 :

$$
\begin{aligned}
& \mathrm{U}=\mathrm{V}_{1}-\left(\mathrm{BF}_{1}+\mathrm{GW}_{1}\right) \\
& \mathrm{U}=3.73 \times 10^{9} \mathrm{ft}^{3}-\left(2.71 \times 10^{9} \mathrm{ft}^{3}+2.72 \times 10^{8} \mathrm{ft}^{3}\right) \\
& \mathrm{U}=7.48 \times 10^{8} \mathrm{ft}^{3}=3.98 \mathrm{in} / \mathrm{yr} .
\end{aligned}
$$

Underflow from the Little Lehigh Creek basin above streamflow-gaging station 01451500 to the Cedar Creek basin is, therefore, calculated to be $3.98 \mathrm{in.} \mathrm{for} \mathrm{1987.} \mathrm{This} \mathrm{is} \mathrm{in} \mathrm{fair} \mathrm{agreement} \mathrm{with} \mathrm{an} \mathrm{underflow} \mathrm{of} 2.6 \mathrm{in} / \mathrm{yr}$ estimated by Wood and others (1972, p. 18). Underflow from the Little Lehigh Creek basin to the Cedar Creek basin is not constant and depends on antecedent conditions, recharge, and stresses applied to the system. The base flow of Little Lehigh Creek at gaging station 01451500 in 1987 (14.44 in.) is only slightly less than the 1975-83 average (14.75 in.); therefore, an underflow of about $4 \mathrm{in} / \mathrm{yr}$ is probably representative of the average underflow.

When the altitude of the water table is above the altitude of the stream surface, ground water discharges to the stream and the stream gains water. As the altitude of the water table increases above the altitude of the stream surface, ground-water discharge to the stream increases. When the altitude of the water table is below the altitude of the stream surface, the stream loses water to the ground-water system. The quantity of streamflow lost is controlled by the vertical hydraulic conductivity of the stream-bottom material, the cross-sectional area of the stream bottom, and the difference between the head in the aquifer and the stream surface when the head in the aquifer is above the streambed or stream depth when the water table is below the stream bottom.

In the western part of the Little Lehigh Creek basin, some streams, particularly the upper reaches of Iron Run, Schaefer Run, and Toad Creek, lose water to the ground-water system. Here the water table is usually several feet to tens of feet below the bottom of streams. When the water table falls below the stream surface, a gaining stream reach becomes a losing reach. In some areas, such as the lower reach of Spring Creek near Trexlertown and the reach of Little Lehigh Creek between Route 100 and East Texas, the carbonate rocks are permeable enough to accept and transmit all available base flow when the altitude of the water table is below the altitude of the stream bed. Streams in the Little. Lehigh Creek basin can have both gaining and losing reaches in close proximity. All streamflow lost in the upper part of the basin eventually returns to the stream as ground-water discharge to gaining reaches in the lower part of the basin, generally downstream from the confluence with Swabia Creek (Wood and others, 1972, p. 127).

Seepage investigations were conducted on Little Lehigh and Cedar Creeks to determine gaining and losing reaches. Streamflow measurement sites are shown on figure 10. Seepage measurements on Little Lehigh Creek were made on May 1, 1985 (table 5), December 4, 1985 (table 6), and May 2, 1986 (table 7). Seepage measurements were made on Cedar Creek on September 11, 1986 (table 8). 
Table 5.--Discharge measured during seepage investigation of Little Lehigh Creek, May 1 , 1985 [Sites are shown on figure $10 ;-$. , no data]

\begin{tabular}{|c|c|c|c|c|c|}
\hline \multirow[b]{3}{*}{$\begin{array}{l}\text { Site } \\
\text { number }\end{array}$} & \multirow[b]{3}{*}{$\begin{array}{l}\text { Stream, location, and } \\
\text { latitude-longitude }\end{array}$} & \multicolumn{4}{|c|}{ Discharge (cubic feet per second) } \\
\hline & & \multirow[b]{2}{*}{ Tributary } & \multirow[b]{2}{*}{$\begin{array}{l}\text { Main } \\
\text { stream }\end{array}$} & \multicolumn{2}{|c|}{$\begin{array}{l}\text { Gain or loss } \\
\text { and (or) measurement error }\end{array}$} \\
\hline & & & & Segment & Cumulative \\
\hline 1 & $\begin{array}{l}\text { Little Lehigh Creek at Weilersville, } \\
200 \text { feet upstream from bridge on } \\
\text { Spring Creek Road } \\
(4031350753635)\end{array}$ & -- & 11.70 & -- & -- \\
\hline 2 & $\begin{array}{l}\text { Spring Creek at Route } 100 \text {, downstream } \\
\text { from bridge } \\
(4032020753603)\end{array}$ & 7.64 & -- & -- & -- \\
\hline 3 & $\begin{array}{l}\text { Little Lehigh Creek below Route } 100 \text {, } \\
\text { below confluence with Spring Creek } \\
(4032070753549)\end{array}$ & -- & 14.9 & 3.2 & 3.2 \\
\hline 4 & $\begin{array}{l}\text { Little Lehigh Creek near Ancient Oaks, } \\
200 \text { feet downstream from bridge } \\
(4032360753444)\end{array}$ & -- & 13.0 & -1.9 & 1.3 \\
\hline 5 & $\begin{array}{l}\text { Swabia Creek above Alburtis, } 100 \text { feet } \\
\text { upstream from Main Street bridge } \\
(4030060753553)\end{array}$ & 2.03 & -- & -- & -- \\
\hline 6 & $\begin{array}{l}\text { Swabia Creek below Macungie, } 50 \text { feet } \\
\text { upstream from Brookside Road bridge } \\
(4031350753259)\end{array}$ & 2.60 & -- & .57 & -- \\
\hline 7 & $\begin{array}{l}\text { Little Lehigh Creek above turnpike } \\
\text { bridge, } 0.33 \mathrm{miles} \text { upstream from } \\
\text { turnpike bridge } \\
(4032160753141)\end{array}$ & -- & 15.5 & 2.5 & 3.8 \\
\hline 8 & $\begin{array}{l}\text { Leiberts Creek at Emmaus, } 200 \text { feet } \\
\text { downstream from Shimerville Road } \\
\text { bridge } \\
\left(\begin{array}{ll}403217 & 0753123)\end{array}\right.\end{array}$ & 1.35 & -- & -- & -- \\
\hline 10 & $\begin{array}{l}\text { Little Lehigh Creek at Emmaus, } 210 \text { feet } \\
\text { downstream from Orchard Street bridge } \\
(4032290753042)\end{array}$ & --1 & 24.6 & 2.3 & 12.9 \\
\hline 01451500 & $\begin{array}{l}\text { Little Lehigh Creek near Allentown } \\
\text { at gaging station }\end{array}$ & -- & $1_{45.3}$ & 20.7 & 33.6 \\
\hline
\end{tabular}

1 Discharge from stage and rating table.

The seepage investigations show that losing reaches can become gaining reaches. On May 1,1985 , the reach of Little Lehigh Creek between Weilersville (4031350753635) and Ancient Oaks (4032360753444) lost $6.3 \mathrm{ft}^{3} / \mathrm{s}$. The reach from below the confluence with Spring Creek (4032070753549) to Ancient Oaks lost $1.9 \mathrm{ft}^{3} / \mathrm{s}$. On December 4, 1985, the reach between Weilersville to Ancient Oaks gained $18.6 \mathrm{ft}^{3} / \mathrm{s}$. The reach from below the confluence with Spring Creek to Ancient Oaks gained $2.7 \mathrm{ft} 3 / \mathrm{s}$. On May 2, 1986, the reach between Weilersville and below the confluence wi.th Spring Creek gained $1.7 \mathrm{ft}^{3} / \mathrm{s}$.

Median ground-water temperatures measured by Wood and others (1972, p. 120) were 11 to $12{ }^{\circ} \mathrm{C}$ (degrees Celsius). Surface-water-temperature measurements made during the May 2, 1986, seepage investigation (table 7) are an indicator of ground-water discharge. Higher water temperatures (14.5 to 
Table 6.--Discharge measured during seepage investigation of Little Lehigh Creek, December 4 , 1985 [Sites are shown on figure 10 ; --, no data]

\begin{tabular}{|c|c|c|c|c|}
\hline \multirow{2}{*}{$\begin{array}{l}\text { Site } \\
\text { number }\end{array}$} & \multirow{2}{*}{$\begin{array}{l}\text { Stream, location, and } \\
\text { latitude-longitude }\end{array}$} & Dischar & $\begin{array}{r}\text { bic feet } \\
\text { Gai } \\
\text { nd(or) me }\end{array}$ & $\begin{array}{l}\text { second) } \\
\text { rement error } \\
\text { rement }\end{array}$ \\
\hline & & stream & Segment & Cumulative \\
\hline 1 & $\begin{array}{l}\text { Little Lehigh Creek at Weilersville, } \\
\text { 150 feet upstream from bridge on Spring } \\
\text { Creek Road } \\
(4031350753635)\end{array}$ & 47.3 & -- & -- \\
\hline 3 & $\begin{array}{l}\text { Little Lehigh Creek below Route } 100 \text {, } \\
300 \text { feet below confluence with Spring } \\
\text { Creek } \\
(4032070753549)\end{array}$ & 63.2 & 15.9 & 15.9 \\
\hline 4 & $\begin{array}{l}\text { Little Lehigh Creek near Ancient Oaks, } \\
20 \text { feet downstream from farm bridge } \\
(4032360753444)\end{array}$ & 65.9 & 2.7 & 18.6 \\
\hline 01451500 & $\begin{array}{l}\text { Little Lehigh Creek near Allentown } \\
\text { at gaging station }\end{array}$ & 1125 & 42.6 & 77.7 \\
\hline
\end{tabular}

1 Discharge from stage and rating table.

$18{ }^{\circ} \mathrm{C}$ ) indicate that streamflow is mainly surface runoff. Lower water temperatures ( 11 to $12^{\circ} \mathrm{C}$ ) indicate that streamflow is mainly ground-water discharge.

The seepage investigation conducted on Cedar Creek on September 11, 1986 (table 8), showed that Cedar Creek gained water at all measurement sites.

Geology is a major factor in ground-water/surface-water relations and streamflow characteristics. Streams flowing over noncarbonate rock are generally gaining streams; streams flowing over carbonate rock can have gaining and losing reaches, depending on the altitude of the water table. Streamflow characteristics at three gaging stations in the Little Lehigh Creek basin were compared to show the effect of geology on streamflow. Little Lehigh Creek above the gaging station near Allentown (station number 01451500) drains primarily carbonate rock. Jordan Creek above the gaging station near Schnecksville (station number 01451800) drains primarily noncarbonate rock, Jordan Creek above the gaging station at Allentown (station number 01452000) drains both carbonate and noncarbonate rock, and Jordan Creek between the Schnecksville and Allentown gaging stations drains primarily carbonate rock. The drainage areas at the gaging stations are $80.8,53.0$, and $75.8 \mathrm{mi}^{2}$, respectively. The drainage area of Jordan Creek between the Schnecksville and Allentown gaging stations is $22.8 \mathrm{mi}^{2}$. A common period of record, 1967-86, was used for the following analysis. The discharge of Jordan Creek between the Schnecksville and Allentown gaging stations was determined by subtracting the mean daily discharge at the Schnecksville gaging station from the mean daily discharge at the Allentown gaging station. When the difference in flow was less than zero, indicating a net loss of water in this reach, streamflow 
Table 7.--Discharge and water temperature measured during seepage investigation of Little Lehigh Creek, May 2 , 1986 [Sites are shown on figure $10 ;-\cdots$, no data]

\begin{tabular}{|c|c|c|c|c|c|c|}
\hline \multirow{3}{*}{$\begin{array}{l}\text { Site } \\
\text { number }\end{array}$} & \multirow{3}{*}{$\begin{array}{l}\text { Stream, location, and } \\
\text { latitude-longitude }\end{array}$} & \multicolumn{4}{|c|}{ Discharge (cubic feet per second) } & \multirow{3}{*}{$\begin{array}{c}\text { Stream } \\
\text { temperature } \\
\text { (degrees Celsius) }\end{array}$} \\
\hline & & \multirow[b]{2}{*}{ Tributary } & \multirow{2}{*}{$\begin{array}{l}\text { Matn } \\
\text { stroam }\end{array}$} & \multicolumn{2}{|c|}{$\begin{array}{l}\text { Gain or loss and(or) } \\
\text { measurement error }\end{array}$} & \\
\hline & & & & Segment & Cumulative & \\
\hline 11 & $\begin{array}{l}\text { Little Lehigh Creek above Weilersville, } \\
5 \text { feet downstream from bridge } \\
(4031330753723)\end{array}$ & -- & 22.6 & -- & -- & 16.0 \\
\hline 1 & $\begin{array}{l}\text { Little Lehigh Creek at Weilersville, } 200 \\
\text { feet upstream from bridge on Spring } \\
\text { Creek Road } \\
(4031350753635)\end{array}$ & -- & 26.3 & 3.7 & 3.7 & -- \\
\hline 12 & $\begin{array}{l}\text { Iron Run at Bull Frog Road, } 100 \text { feet } \\
\text { downstream from Bull Frog Road bridge } \\
(4034150753913)\end{array}$ & -- & -- & -- & -- & 15.0 \\
\hline 13 & $\begin{array}{l}\text { Iron Run at Schantz Spring Road between } \\
\text { Bul1 Frog and Schantz Spring Roads } \\
(4034120753742)\end{array}$ & -- & -- & -- & -- & 17.0 \\
\hline 14 & $\begin{array}{l}\text { Iron Run below Grim Road, } 30 \text { feet } \\
\text { downstream from bridge } \\
(4033570753705)\end{array}$ & -- & -- & -- & -- & 17.0 \\
\hline 15 & $\begin{array}{l}\text { Schaefer Run downstream from intersection } \\
\text { of Route } 222 \text { and Old Breinigsville } \\
\text { Highway } \\
(4032230753725)\end{array}$ & -- & -- & -- & -- & 18.0 \\
\hline 2 & $\begin{array}{l}\text { Spring Creek at Route } 100 \text { downstream from } \\
\text { bridge } \\
(4032020753603)\end{array}$ & 29.6 & -- & - & - & 14.5 \\
\hline 3 & $\begin{array}{l}\text { Little Lehigh Creek below Route } 100 \text {, below } \\
\text { confluence with Spring Creek } \\
\text { (403207 0753549) }\end{array}$ & - & 57.6 & 31.3 & 35.0 & -- \\
\hline 4 & $\begin{array}{l}\text { Little Lehigh Creek near Ancient Oaks, } \\
200 \text { feet downstream from farm bridge } \\
(4032360753444)\end{array}$ & -- & 54.7 & -2.9 & 32.1 & 12.0 \\
\hline 16 & $\begin{array}{l}\text { Little Lehigh Creek near East Texas, below } \\
\text { bridge on Willow Lane } \\
(403221 \text { 0753352) }\end{array}$ & - & 65.9 & 11.2 & 43.3 & 11.0 \\
\hline 6 & $\begin{array}{l}\text { Swabia Creek below Macungie, } 50 \text { feet } \\
\text { upstream from Brookside Road bridge } \\
(4031350753259)\end{array}$ & 13.4 & -- & -- & -- & 11.0 \\
\hline 7 & $\begin{array}{l}\text { Little Lehigh Creek above turnpike bridge, } \\
0.33 \text { miles upstream from turnpike bridge } \\
(4032160753141)\end{array}$ & -- & 95.6 & 29.7 & 73.0 & 11.5 \\
\hline 01451500 & $\begin{array}{l}\text { Little Lehigh Creek near Allentown at } \\
\text { gaging station }\end{array}$ & -- & 1117 & 21.4 & 94.4 & -- \\
\hline
\end{tabular}

1 Discharge from stage and rating table.

was set equal to zero. During 1967-86, the difference in flow between the gaging stations was less than zero on 559 days or 8 percent of the time. Base flow was estimated by hydrograph separation (local-minimum technique) using the computer program of sloto (1991).

Streams that drain carbonate rock have lower streamflow, a lower percentage of overland runoff, and a more sustained base flow. The streamflow frequency distribution (fig. 11), base-flow frequency distribution (fig. 12), and summary (table 9) are given in inches so that the different-size drainage basins can be compared. Little Lehigh Creek, which drains primarily carbonate rock, has lower streamflow (fig. 11), higher base flow (fig. 12), a lower percentage of streamflow as overland runoff, and a greater percentage of 
Table 8.--Discharge and water temperature measured during seepage investigation of Cedar Creek, September 11 , 1986 [Sites are shown on figure 10 ; --, no data]

\begin{tabular}{|c|c|c|c|c|c|c|}
\hline \multirow{2}{*}{$\begin{array}{l}\text { Site } \\
\text { number }\end{array}$} & \multirow{2}{*}{$\begin{array}{l}\text { Stream, location, and } \\
\text { latitude-longitude }\end{array}$} & \multicolumn{4}{|c|}{$\begin{array}{c}\text { Discharge (cubic feet per second) } \\
\text { Gain or loss and(or) } \\
\text { measurement error }\end{array}$} & \multirow{2}{*}{$\begin{array}{c}\text { Stream } \\
\text { temperature } \\
\text { (degrees Celsius) }\end{array}$} \\
\hline & & Tributary & stream & Segment & Cumulative & \\
\hline 17 & $\begin{array}{l}\text { Cedar Creek, } 1,000 \text { feet below Schantz } \\
\text { Spring, 100 feet below bridge } \\
(4034400753303)\end{array}$ & -- & 1.03. & -- & -- & 14.0 \\
\hline 18 & $\begin{array}{l}\text { Cedar Creek, } 100 \text { feet below bridge } \\
\text { near County Home } \\
(4034420753235)\end{array}$ & -- & 2.29 & 1.26 & 1.26 & 13.0 \\
\hline 19 & $\begin{array}{l}\text { Cedar Creek, } 25 \text { feet above bridge } \\
\text { on Main Blvd. } \\
\text { ( } 4035000753153)\end{array}$ & -- & 10.3 & 8.0 & 9.3 & 13.5 \\
\hline 20 & $\begin{array}{l}\text { Little Cedar Creek, bridge at west end } \\
\text { of golf course } \\
(4036020753250)\end{array}$ & Dry & -- & -- & -- & -- \\
\hline 21 & $\begin{array}{l}\text { Little Cedar Creek, } 35 \text { feet above bridge } \\
\text { in southern Trexler Memorial Park } \\
(4035240753136)\end{array}$ & 2.10 & -- & 2.10 & -- & 17.5 \\
\hline 22 & $\begin{array}{l}\text { Cedar Creek, } 15 \text { feet above central bridge } \\
\text { in Cedar Creek Park } \\
(4035370753045)\end{array}$ & -- & 14.7 & 4.4 & 13.7 & 16.0 \\
\hline 23 & $\begin{array}{l}\text { Cedar Creek, } 1,500 \text { feet above confluence } \\
\text { with Little Lehigh Creek } \\
(4035150752942)\end{array}$ & -- & 15.3 & .6 & 14.3 & 17.0 \\
\hline
\end{tabular}

streamflow as base flow (table 9) than does Jordan Creek near Schnecksville, which drains primarily noncarbonate rock. Jordan Creek near Schnecksville has a higher streamflow (fig. 11) than the other stream reaches.

Jordan Creek between the Schnecksville and Allentown gaging stations, which drains primarily carbonate rock, has the lowest base flow of all the stations (fig. 12) and lower streamflow (fig. 11) than Jordan Creek near Schnecksville. In the reach between Schnecksville and Allentown, Jordan Creek loses large quantities of streamflow to the ground-water system. Wood and others (1972, p. 142) estimated that Jordan Creek goes completely dry in this reach about once every 2 years. Streamflow loss in this reach is related to ground-water levels and was described by Wood and others (1972, p. 142-154). Some of the streamflow lost in this reach becomes ground-water underflow from the Jordan Creek basin to the Lehigh River. 
Table 9.--Average streamflow and base flow of Little Lehigh and Jordan Creeks, $1967-86$

[mi ${ }^{2}$, square miles]

\begin{tabular}{|c|c|c|c|c|c|}
\hline Gaging station & $\begin{array}{l}\text { Predominant } \\
\text { type of } \\
\text { rock }\end{array}$ & $\begin{array}{c}\text { Drainage } \\
\text { area } \\
\left(m i^{2}\right)\end{array}$ & $\begin{array}{l}\text { Average } \\
\text { streamflow } \\
\text { (inches) }\end{array}$ & $\begin{array}{l}\text { Average } \\
\text { base flow } \\
\text { (inches) }\end{array}$ & $\begin{array}{l}\text { Percent of } \\
\text { streamflow } \\
\text { as base flow }\end{array}$ \\
\hline Little Lehigh Creek near Allentown & carbonate & 80.8 & 18.81 & 14.70 & 78.1 \\
\hline Jordan Creek near Schnecksville & noncarbonate & 53.0 & 24.00 & 11.92 & 49.7 \\
\hline Jordan Creek at Allentown & $\begin{array}{l}\text { carbonate and } \\
\text { noncarbonate }\end{array}$ & 75.8 & 22.04 & 11.03 & 50.0 \\
\hline $\begin{array}{l}\text { Jordan Creek between } \\
\text { Schnecksville and } \\
\text { Allentown gages }\end{array}$ & carbonate & 22.8 & 17.47 & 8.98 & 51.4 \\
\hline
\end{tabular}

\section{Water Budget}

A water budget is an estimate of the quantity of water entering and leaving an area for a given period of time. The water budget balances water entering the area as precipitation with water leaving as streamflow, exported water, and evapotranspiration, taking into account any changes in storage. The water budget can be expressed as

$$
P=S F+U+D I V+D S+E T,
$$

where

$$
\begin{aligned}
\mathrm{P} & =\text { precipitation, } \\
\mathrm{SF} & =\text { streamflow } \\
\mathrm{U} & =\text { underflow, } \\
\text { DIV } & =\text { diversions exported from the basin, } \\
\text { DS } & =\text { change in ground-water storage, and } \\
\mathrm{ET} & =\text { evapotranspiration. }
\end{aligned}
$$

Water budgets for 1975-83 and the average budget for those years are presented for the 80.8- $\mathrm{mi}^{2}$ part of the Little Lehigh Creek basin above gaging station 01451500 (table 10). The average water budget for 1975-83 is not a long-term average because the period spans only 9 years; however, this period can be used to approximate long-term conditions. Soil moisture generally is at field capacity in the winter. The period for the water budget begins and ends in winter; therefore, the change in soil moisture is assumed to be negligible and a soil-moisture term is not included in equation 5. Waterlevel records from continuous-record observation wells BE-623 and LE-860 were used to estimate the annual change in ground-water storage. Information on diversions was supplied by the Pennsylvania Department of Environmental Resources, the Lehigh County Authority, the City of Allentown Water Department, water purveyors in South Whitehall Township, and the boroughs of Emmaus, Macungie, and Topton. Precipitation is from the National Weather Service station at the Allentown-Bethlehem-Elaston Airport near Allentown. Underflow is a constant; it is the average value estimated using data for 1987. Evapotranspiration is the unknown term for which equation 5 is solved. Errors in the other terms of the water-budget equation are included in the evapotranspiration term. 


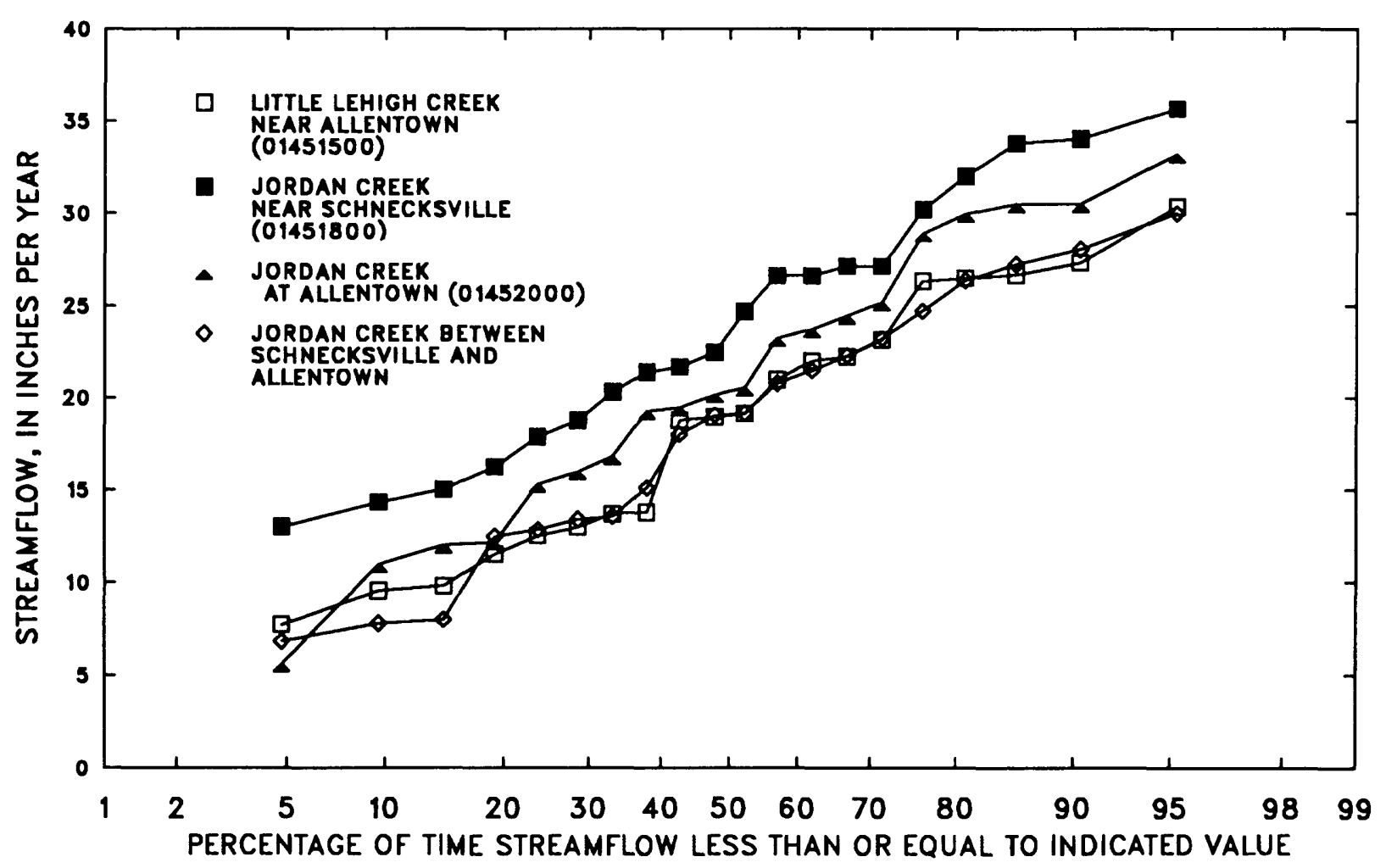

Figure 11.--Frequency distribution of streamflow, Little Lehigh and Jordan Creeks, 1967-86.

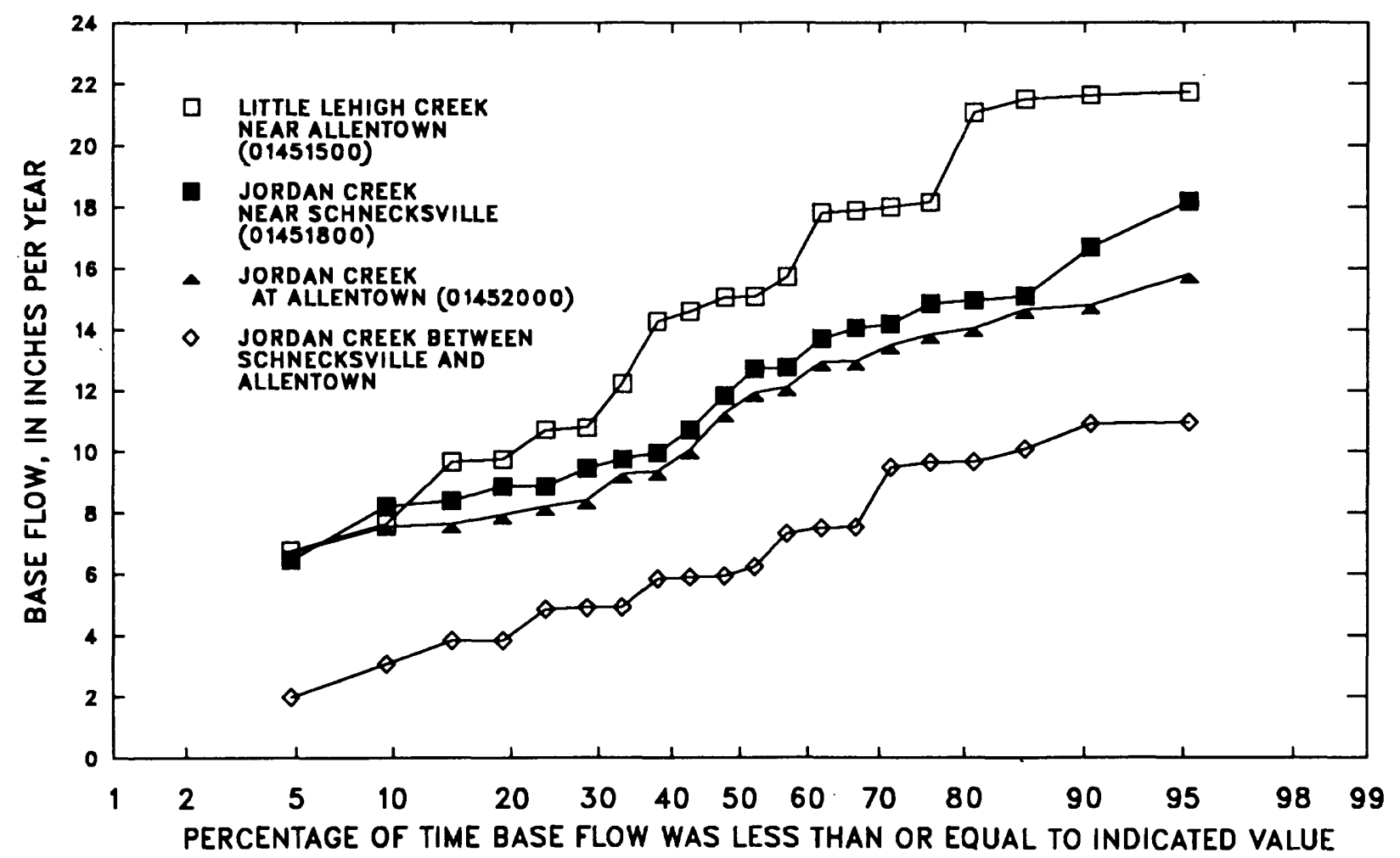

Figure 12.--Frequency distribution of base flow, Little Lehigh and Jordan Creeks, 1967-86. 
Table 10.--Water budgets for the Little Lehigh Creek basin, 1975-83 [Units are in inches per year]

\begin{tabular}{lcccc|cc}
\hline Year & $\begin{array}{c}\text { Precip- } \\
\text { itation }\end{array}$ & $\begin{array}{c}\text { Stream- } \\
\text { flow }\end{array}$ & Underflow & Diversions & $\begin{array}{c}\text { Change in ground- } \\
\text { water storage } \\
\text { transpiration }\end{array}$ \\
\hline & & & & & & 21.92 \\
1975 & 55.54 & 26.64 & 4.00 & 0.93 & 2.05 & 19.78 \\
1976 & 39.90 & 18.94 & 4.00 & 1.22 & -4.04 & 20.81 \\
1977 & 49.60 & 19.20 & 4.00 & 1.23 & 4.36 & 21.38 \\
1978 & 45.99 & 23.17 & 4.00 & 1.31 & -3.87 & 16.47 \\
1979 & 49.71 & 26.49 & 4.00 & 1.29 & 1.46 & 14.27 \\
1980 & 29.83 & 13.85 & 4.00 & 1.45 & -3.74 & 22.99 \\
1981 & 35.08 & 7.75 & 4.00 & 1.38 & -1.04 & 22.62 \\
1982 & 43.40 & 13.71 & 4.00 & 1.42 & 1.65 & 20.53 \\
1983 & 52.70 & 22.07 & 4.00 & 1.49 & 4.61 & 20.09 \\
Average & 44.64 & 19.09 & 4.00 & 1.30 & .16 & \\
\hline
\end{tabular}

The annual water-level changes in wells BE-623 and LE-860 were averaged to calculate annual change in ground-water storage. The annual water-level change was calculated by subtracting the water level on December 31 from the water level on January 1 . The average annual water-level change was multiplied by a specific yield of 0.05 to estimate the change in ground-water storage.

The average annual water-level change in wells BE-623 and LE-860 is assumed to be representative of the annual water-level change in the Little Lehigh Creek basin. Well BE-623 is an unused $385-\mathrm{ft}$ well drilled in the Leithsville Formation. Well LE-860 is an unused $100-\mathrm{ft}$ well drilled in the Allentown Dolomite. Ideally, water levels from more than two wells should be used to calculate change in ground-water storage. However, data were available only from these two we11s and well LE-644. Data from well LE-644 were not used for calculating ground-water storage because of the large range in annual water-level fluctuation, which is as much as $39.22 \mathrm{ft}$. The large annual water-level fluctuations produced very large changes in ground-water storage when a specific yield of 0.05 was used. Maximum annual water-level fluctuations for $1975-83$ are $10.67 \mathrm{ft}$ for BE-623 and $5.78 \mathrm{ft}$ for LE-860.

The average specific yield for the carbonate rocks in the Little Lehigh Creek basin was estimated by using the following equation (Meisler, 1963, p. 32):

$$
\text { Sy }=\frac{q-R}{d V} \text {, }
$$

where $\quad S y=$ the average specific yield for the basin,

$q=$ total quantity of base flow discharged from the Little Lehigh Creek basin measured at gaging station 01451500,

$R=$ total recharge added to the ground-water system, and $\mathrm{dV}=$ the change in volume of dewatered rock.

For periods with no recharge this equation becomes

$$
\text { Sy }=\frac{q}{d V} \text {. }
$$


Six periods, 10 to 14 days long between August 19, 1981, and September 11, 1983, were selected for this analysis. During these periods, no precipitation or snow melt took place, and therefore, no recharge. Each period began at least 3 days after precipitation to assure that direct runoff left the basin. The change in volume of the dewatered rock (dV) was calculated by multiplying the average water-level decline in well LE-860 for a given period by the total drainage area above the gaging station. The accuracy of the calculated basin specific yield depends on how closely the water-level decline in well LE-860 approximates the water-level decline in the entire basin.

An example calculation for May $2-11,1982$, is

$$
\begin{aligned}
& \mathrm{q}= 7.59 \times 10^{7} \mathrm{ft}^{3} \text { (total outflow from basin), } \\
& \mathrm{dV}= 0.65 \mathrm{ft}(10 \text {-day decline in we11 LE-860) } \\
& \quad \times 2.25 \times 10^{9} \mathrm{ft}^{2}\left(\text { area of basin) }=1.46 \times 10^{9} \mathrm{ft}^{3} ;\right.
\end{aligned}
$$

therefore,

$$
\text { Sy }=\frac{7.59 \times 10^{7} \mathrm{ft}^{3}}{1.46 \times 10^{9} \mathrm{ft}^{3}}=0.052 \text {. }
$$

The calculated specific yield of the zone of water-table fluctuation in the carbonate rocks of the Little Lehigh Creek basin ranged from 0.034 to 0.065 and averaged 0.051 or about 5 percent (table 11). Average specific yield in similar areas in Pennsylvania are 5 percent for the carbonate rocks of the Lebanon Valley (Meisler, 1963), and 4 percent for the carbonate rocks of the Lancaster Quadrangle (Meisler and Becher, 1971). Wood and others (1972, p. 111) used 4.4 percent for the carbonate rocks of the Lehigh Valley.

Underflow was estimated using data for 1987 (see section on GroundWater/Surface-Water Relations). Because data are not available for 1975-83, the estimated 1987 average underflow was used for each year in the water budget. However, the quantity of underflow varies from year to year depending on climatic conditions and is not known for 1975-83. Use of an average underflow causes an underestimation or overestimation of annual evapotranspiration in table 10, the unknown for which equation 5 is solved. Although annual estimates of evapotranspiration in table 10 are affected by estimating underflow, the 1975-83 average evapotranspiration is probably not affected. The 1975-83 average evapotranspiration is lower than the evapotranspiration of $26.4 \mathrm{in}$. for the Little Lehigh Creek basin and $24.5 \mathrm{in}$. for the Jordan Creek basin estimated by Wood and others (1972, p. 18 and 26) for 1946-62.

Table 11.--Estimates of specific yield for the Little Lehigh Creek basin

\begin{tabular}{lccc}
\hline & $\begin{array}{c}\text { Change in water } \\
\text { Bevel in LE-860 } \\
\text { Period }\end{array}$ & $\begin{array}{c}\text { (cubic feet) } \\
\text { (feet) }\end{array}$ & Specific yield \\
\hline August 19-29, 1981 & $2.85 \times 10^{7}$ & 0.32 & 0.040 \\
May 2-11, 1982 & $7.59 \times 10^{7}$ & .65 & .052 \\
September 6-19, 1982 & $7.10 \times 10^{7}$ & .54 & .058 \\
October 1-12, 1982 & $3.44 \times 10^{7}$ & .45 & .034 \\
August 16-27, 1983 & $5.59 \times 10^{7}$ & .38 & .065 \\
September 1-11, 1983 & $4.79 \times 10^{7}$ & .37 & .058 \\
Average & & & .051
\end{tabular}


Annual recharge and average recharge for 1975-83 was estimated for Little Lehigh Creek above gaging station 01451500 (table 12). The recharge rates were calculated by using the following equation:

$$
\mathrm{R}=\mathrm{BF}+\mathrm{GWET}+\mathrm{DIV}+\mathrm{DS}+\mathrm{U} \text {, }
$$

where

$$
\begin{aligned}
\mathrm{R} & =\text { recharge } \\
\mathrm{BF} & =\text { base flow } \\
\mathrm{GWET} & =\text { ground-water evapotranspiration, } \\
\mathrm{DIV} & =\text { diversions exported from the basin, } \\
\mathrm{DS} & =\text { change in ground-water storage, and } \\
\mathrm{U} & =\text { underflow. }
\end{aligned}
$$

Base flow was estimated by hydrograph separation (local-minimum

\begin{tabular}{|c|c|c|c|c|c|c|}
\hline Year & Recharge & $\begin{array}{l}\text { Base } \\
\text { flow }\end{array}$ & $\begin{array}{l}\text { Ground-water } \\
\text { evapotranspiration }\end{array}$ & Diversions & $\begin{array}{l}\text { Change in ground- } \\
\text { is water storage }\end{array}$ & $\begin{array}{l}\text { Under- } \\
\text { flow }\end{array}$ \\
\hline 1975 & 29.98 & 21.50 & 1.50 & 0.93 & 2.05 & 4.00 \\
\hline 1976 & 17.73 & 15.05 & 1.50 & 1.22 & -4.04 & 4.00 \\
\hline 1977 & 26.17 & 15.08 & 1.50 & 1.23 & 4. 36 & 4.00 \\
\hline 1978 & 20.75 & 17.81 & 1.50 & 1.31 & -3.87 & 4.00 \\
\hline 1979 & 26.40 & 18.15 & 1.50 & 1.29 & 1.46 & 4.00 \\
\hline 1980 & 15.42 & 12.21 & 1.50 & 1.45 & -3.74 & 4.00 \\
\hline 1981 & 12.60 & 6.76 & 1.50 & 1.38 & -1.04 & 4.00 \\
\hline 1982 & 19.35 & 10.78 & 1.50 & 1.42 & 1.65 & 4.00 \\
\hline 1983 & 27.31 & 15.71 & 1.50 & 1.49 & 4.61 & 4.00 \\
\hline Average & e 21.75 & 14.78 & 1.50 & 1.30 & .16 & 4.00 \\
\hline
\end{tabular}
technique) with data from Little Lehigh Creek near Allentown (station number 01451500) using the computer program of sloto (1991). Ground-water evapotranspiration was estimated. Ground-water diversions and changes in ground-water storage were based on the basin water budgets (table 10).

Table 12.--Recharge to the Little Lehigh Creek basin, 1975-83 [Units are inches per year]

Underflow was estimated using data for 1987 (see section on GroundWater/Surface-Water Relations). Because data are not available for 1975-83, the estimated 1987 average underflow was used for each year in the water budget. The quantity of underflow varies from year to year depending on climatic conditions. Use of an average underflow causes an underestimation or overestimation of annual recharge (table 12), but probably does not affect the 1975-83 average recharge.

Estimated annual recharge for $1975-83$ ranged from 12.60 to 29.98 in/yr; the average recharge was $21.75 \mathrm{in} / \mathrm{yr}$. Base flow was equal to 54 to 86 percent of recharge; for 1975-83, the average annual base flow was 68 percent of average annual recharge. 
The carbonate rocks of the Lehigh Valley form a complex, heterogeneous water-table aquifer that fluctuates in response to recharge from precipitation and discharge to pumping wells, ground-water evapotranspiration, and streams. The water table generally rises during the fall and winter when evapotranspiration is at a minimum and recharge is at a maximum; it generally declines during the spring and summer when evapotranspiration is at a maximum and recharge is at a minimum (fig. 13). Figure 13 shows the hydrographs of wells LE- 644 and LE-860. Well LE-644 is a 184-ft well drilled in the Beekmantown Group close to Iron Run; LE-860 is a $100-\mathrm{ft}$ well drilled in the Allentown Dolomite near Little Lehigh Creek. Hydrographs of both wells show similar patterns of annual fluctuations; however, the range of fluctuation differs considerably. The water level in well LE-644 fluctuated $56 \mathrm{ft}$ during 1971-85, while the water level in well LE-860 fluctuated $12 \mathrm{ft}$ during the same period. Well LE-644 is located along a losing reach of Iron Run that is often dry, and the water table is tens of feet below the stream bed. Well LE-860 is located along a reach of Little Lehigh Creek that periodically gains or loses water, depending on the altitude of the water table, which is within a few feet of land surface.

\section{Schantz and Crystal Springs}

Schantz and Crystal Springs (pl. 1) are a major source of water for the city of Allentown. From 1969-84, Schantz and Crystal Springs (LE-Sp-15 and LE-Sp-14, respectively) provided an average of 43 percent of the water supplied by the Allentown Water Department.

Schantz Spring is located near the contact between the Allentown Dolomite and the Epler Formation of the Beekmantown Group at an elevation of $340 \mathrm{ft}$. The contact is interpreted to be a shallow thrust fault that dips about $15^{\circ}$ southeast and brings the Allentown Dolomite up over the Epler Formation (Drake, A.A., Jr., U.S. Geological Survey, oral commun., 1988). Crystal Spring is located in the Allentown Dolomite at an elevation of $265 \mathrm{ft}$.

The size of the Schantz Spring ground-water basin, in part, controls the discharge of Schantz Spring. The size of the ground-water basin changes when the ground-water divides that delineate it shift because of changes in recharge or withdrawals. Wood and others (1972, p. 21 and pl. 1) determined that the ground-water basin that drains to Schantz Spring is an elongated area of approximately $10.4 \mathrm{mi}^{2}$ that extends northwestward from the spring to the headwaters of Iron Run. They estimated that $8.25 \mathrm{mi}^{2}$ of this basin underlies the surface-water basin for Iron Run, a tributary to Little Lehigh Creek above gaging station 01451500, and that $2.15 \mathrm{mi}^{2}$ underlies the surface-water basin for Cedar Creek.

In the area between Schantz Spring and Iron Run, the rocks of the Beekmantown Group, especially the Epler Formation, appear to be especially susceptible to solution, and karst topography is well-developed. In this area, Kochanov (1987) mapped numerous karst features, such as sinkholes and 

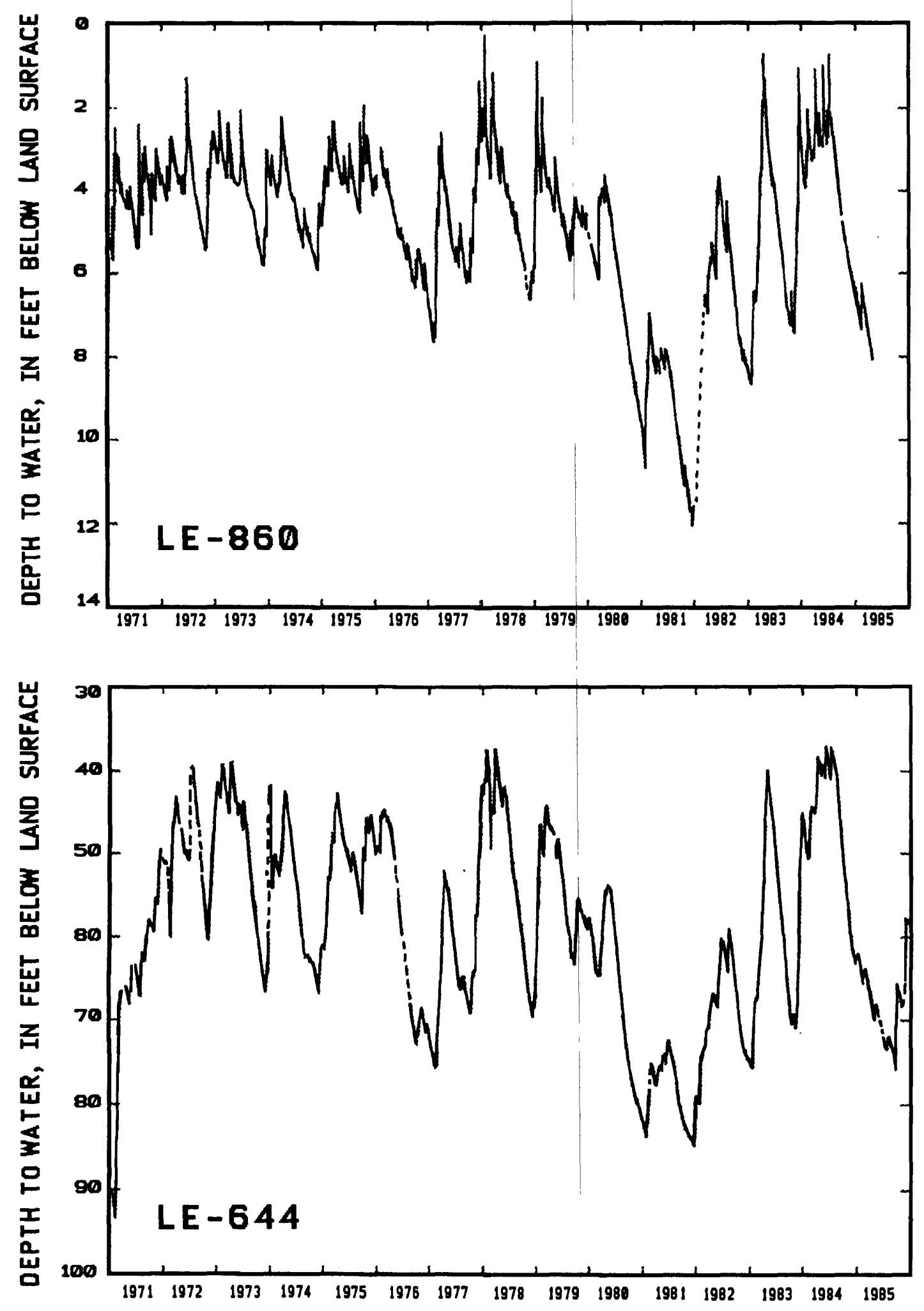

Figure 13.--Hydrographs of wells LE-644 and LE-860, 1971-85. Line dashed where data are missing. 
closed depressions. A sinkhole is a localized, gradual or rapid sinking of the land surface characterized by a roughly circular outline, a distinct breaking of the ground surface, and downward movement of soil into bedrock voids. A closed depression is a distinct bowl-shaped depression in the land surface characterized by an unbroken ground surface and internal drainage. The only streams in this area are ephemeral streams that drain into sinkholes. The lack of surface drainage indicates that recharge to this area may be enhanced.

The absence of surface drainage and the presence of well-developed karst features indicates the presence of an arterial subsurface drainage network. The outlet of this network is probably Schantz spring, which could have developed as the result of the interruption of a main conduit of the network by the thrust fault between the Allentown Dolomite and the Beekmantown Group. Structural juxtaposition of the two geologic units could create a hydrologic barrier or the thrust fault may abruptly terminate structurally or stratigraphically controlled flow paths. The 1968 water-table map of Wood and others (1972, pl. 4a) shows a steepening of the hydraulic gradient around Schantz spring in a pattern nearly coincident with the mapped fault, suggesting that hydraulic conductivity is reduced in the fault area. Either mechanism--structural juxtaposition or termination of preferential flow paths - - could result in a reduction in hydraulic conductivity in the fault area. The steep gradient at the geologic contact also could be a damming effect at the contact between aquifers of different hydraulic conductivities. The hydraulic conductivity of the Epler Formation generally is greater than that of the Allentown Dolomite. Similar mechanisms are probably responsible for Crystal spring.

Part of the flow from the Schantz Spring basin flows beneath the wall of the spring enclosure and discharges to Cedar Creek. Wood and others (1972, p. 22) estimated that this discharge was approximately $0.8 \mathrm{Mgal} / \mathrm{d}$ during 1968 and 1969. Wood and others (1972) also estimated an additional $0.8 \mathrm{Mgal} / \mathrm{d}$ discharged from the basin through other springs along Cedar Creek. Total estimated discharge from the Schantz Spring basin to Cedar Creek, therefore, is about $1.6 \mathrm{Mgal} / \mathrm{d}$. This discharge probably varies roughly in proportion to the natural fluctuations in spring discharge.

Figure 14 shows the average daily discharge (1956-84) for Schantz Spring following reconstruction of the spring basin in 1954-55 and the average daily discharge (1961-84) of Crystal Spring. The average daily discharge from Schantz Spring ranged from 5.2 Mgal/d in 1966 to $8.3 \mathrm{Mgal} / \mathrm{d}$ in 1975 ; the average daily discharge for $1956-84$ (29 years) was $6.9 \mathrm{Mgal} / \mathrm{d}$. The average daily discharge from Crystal Spring ranged from $2.7 \mathrm{Mgal} / \mathrm{d}$ in 1981 to $5.1 \mathrm{Mgal} / \mathrm{d}$ in 1977; the average daily discharge for 1961-84 (24 years) was $4 \mathrm{Mgal} / \mathrm{d}$ (fig. 14). The flow of Schantz Spring correlates better with precipitation (Spearman correlation coefficient $r_{s}=0.69$ ) than does the flow of Crystal Spring $\left(r_{s}=0.40\right)$. 

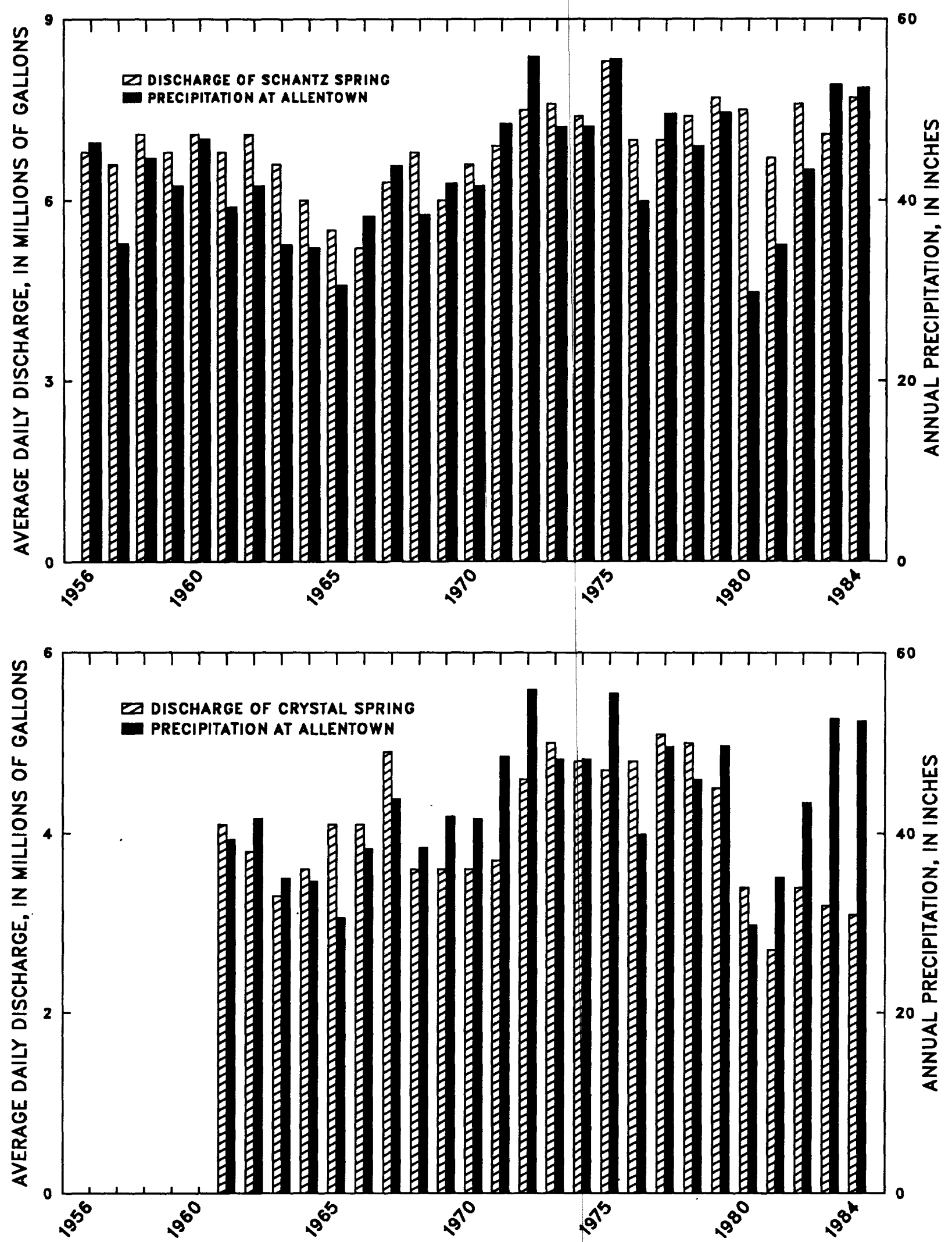

Figure 14.--Average daily discharge of Schantz and Crystal Springs and annual precipitation at Allentown, 1956-84. 
Cessation of pumping from the Lehigh Portland quarry at Fogelsville and development of ground water for public supply in the Schantz Spring basin (as delineated by Wood and others, 1972, p1. 1) has not affected the flow of Schantz Spring (fig. 15). Figure 15 is a double-mass curve of the cumulative flow of Schantz Spring as a function of cumulative precipitation at Allentown for 1956-84, the period following reconstruction of Schantz spring. The straight line indicates that no change in the constant of proportionality between the flow of Schantz Spring and precipitation occurred during 1956-84 (Searcy and Hardison, 1960, p. 33). Pumping from the Lehigh Portland Cement quarry, which averaged $6.6 \mathrm{Mgal} / \mathrm{d}$ in 1968 (Wood and others, 1972, p. 23), ceased in 1971. If cessation of pumping from the quarry caused an increase in the flow of Schantz Spring, a break in the slope of the line on figure 15 would have occurred around 1971. Ground-water pumpage in the Schantz Spring basin during the 10-year period 1975-84 increased 106 percent from $1.43 \mathrm{Mgal} / \mathrm{d}$ in 1975 to $2.94 \mathrm{Mgal} / \mathrm{d}$ in 1984. The effects of this increasing ground-water development cannot be seen in figure 15. Ground-water pumpage data from public supply in the Schantz Spring basin are not available before 1975 .

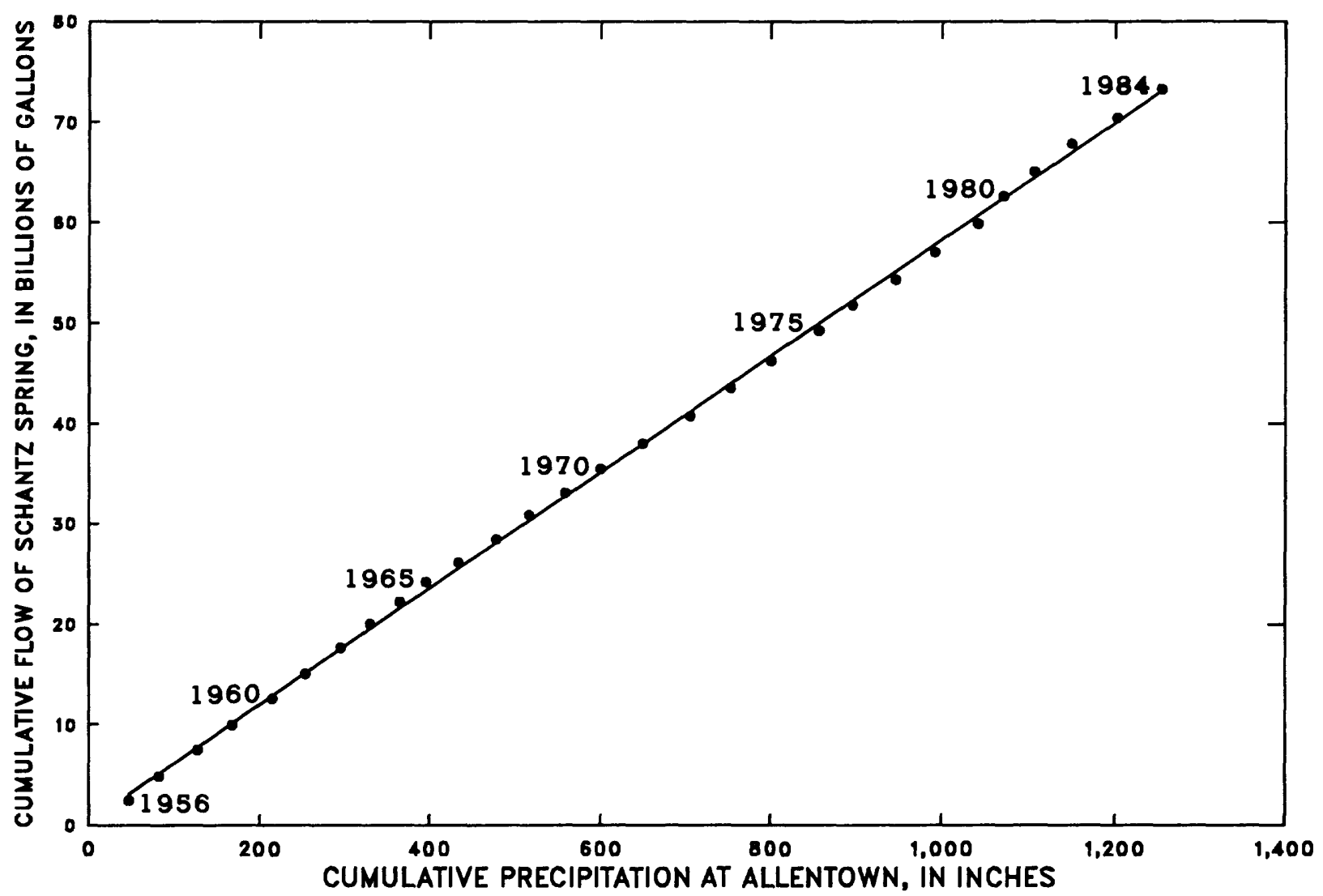

Figure 15.--Double-mass curve of the flow of Schantz Spring as a functon of precipitation at Allentown, 1956-84. 
Although the ground-water system is generally under water-table conditions, confined conditions exist locally. In carbonate rocks, ground water $c$ an be confined by the relatively impermeable sides of a fracture or solution channel. Flowing wells in the Allentawn Dolomite were reported by wood and others (1972, p. 115). However, artesian head is seldom more than a few feet above the water table.

The general direction of ground-water flow through the carbonate rocks in the Little Lehigh Creek basin is east-northeastward toward the Lehigh River. Regional flow directions and the general shape of the water table have not changed substantially since 1968. Figure 16 is part of the 1968 water-table map of Wood and others (1972, pl. 4a) for part of Upper Macungie and Lower Macungie Townships and vicinity. Figure 9 is a water-table map of the same area using water-level data collected in the summer of 1984 and supplemented with additional data collected in January 1989. Figure 9 has fewer control points than Wood and others (1972, pl. 4a) because public water suppliers have increased their distribution area and many of the domestic wells used for the 1968 map have been destroyed. The major change in the water table is the. disappearance of the cone of depression around the former Lehigh Portland quarry, which ceased pumping in 1971. Except for the quarry area, the watertable maps are very similar.

No discernible vertical ground-water flow was observed in brine-trace logs run in three wells (LE-866, LE-1319, and LE-1355). As many as three brine slugs were injected at different depths into a single well and monitored for as long as 9 minutes. If vertical ground-water flow occurs, the flow is too slow to be detected by brine-tracing techniques.

\section{Simulation of Ground-Water Flow}

Ground-water flow in the carbonate rocks of the Little Lehigh Creek basin was simulated using a numerical computer model to estimate the effect of ground-water withdrawals on the base flow of Little Lehigh Creek. The model is a simplified mathematical representation of the complex hydrologic system in the basin. In order to simulate ground-water flow mathematically, certain assumptions regarding the hydrologic system were made and a simplified conceptual model developed. These are described in the following sections. The model approximates the hydrologic system within these imposed constraints and other limitations, which also are discussed below.

The effect of increased ground-water pumping on the base flow of Little Lehigh Creek was estimated using steady-state simulations. The effect of increased ground-water pumping was determined by comparing the base flow of Little Lehigh Creek with the hydrologic system in equilibrium (steady state) before new stress is applied with the base flow of Little Lehigh Creek after the hydrologic system reaches equilibrium (steady state) with the new stress. Steady-state simulations representing equilibrium conditions allow the maximum expected long-term effect of the new stress to be estimated. 


\section{Description of Flow Mode1}

Ground-water flow was simulated using the computer program of McDonald and Harbaugh (1988). The model is a finite-difference, two-dimensional model that uses block-centered nodes. The geologic units in the modeled area were simulated as a single water-table aquifer. Recharge to, ground-water flow through, and discharge from the carbonate rocks of the Little Lehigh Creek basin were simulated.

Sources of water to the modeled carbonate rocks are areally-distributed recharge from precipitation and lateral ground-water flow from noncarbonate rocks to the north and south of the carbonate valley. Discharge of water from the modeled hydrologic system is by pumpage from wells, ground-water discharge to streams, and ground-water evapotranspiration.

\section{Simplified Conceptual Model}

Continuum methods of ground-water-flow analysis, including modeling, assume laminar flow through a medium with primary porosity and permeability (porous media). The geologic units in the Little Lehigh Creek basin have low primary porosity or permeability; ground water mainly flows through secondary openings. However, to permit analysis by continuum methods, the geologic units are assumed to approximate porous media because of the regional scale of analysis. Secondary-opening density is sufficiently great at a regional scale to permit the use of a porous-media model. A block of aquifer material is assumed to have the equivalent properties of the same-size block of porous media. The water-table map of wood and others (1972, p1. 4a) indicates that ground-water flow is continuous on a regional scale.

In order to analyze ground-water flow with a digital model, a simplified conceptual model of the complex physical system was developed. The conceptual model includes the following assumptions:

(1) The geologic units in the Little Lehigh Creek basin act together as a single heterogeneous water-table aquifer. Water-table maps show that the carbonate rocks behave as a single, continuous unit.

(2) A single hydraulic conductivity is specified for each geologic unit. Hydraulic properties of each geologic unit differ spatially, but are averaged for model simulation. The average is considered representative of the geologic unit.

(3) Streams are in direct hydraulic contact with the aquifer.

(4) Ground-water flow below $600 \mathrm{ft}$ is considered negligible. The lower limit of ground-water flow is $600 \mathrm{ft}$ below land surface based on analysis of water-bearing zones. 


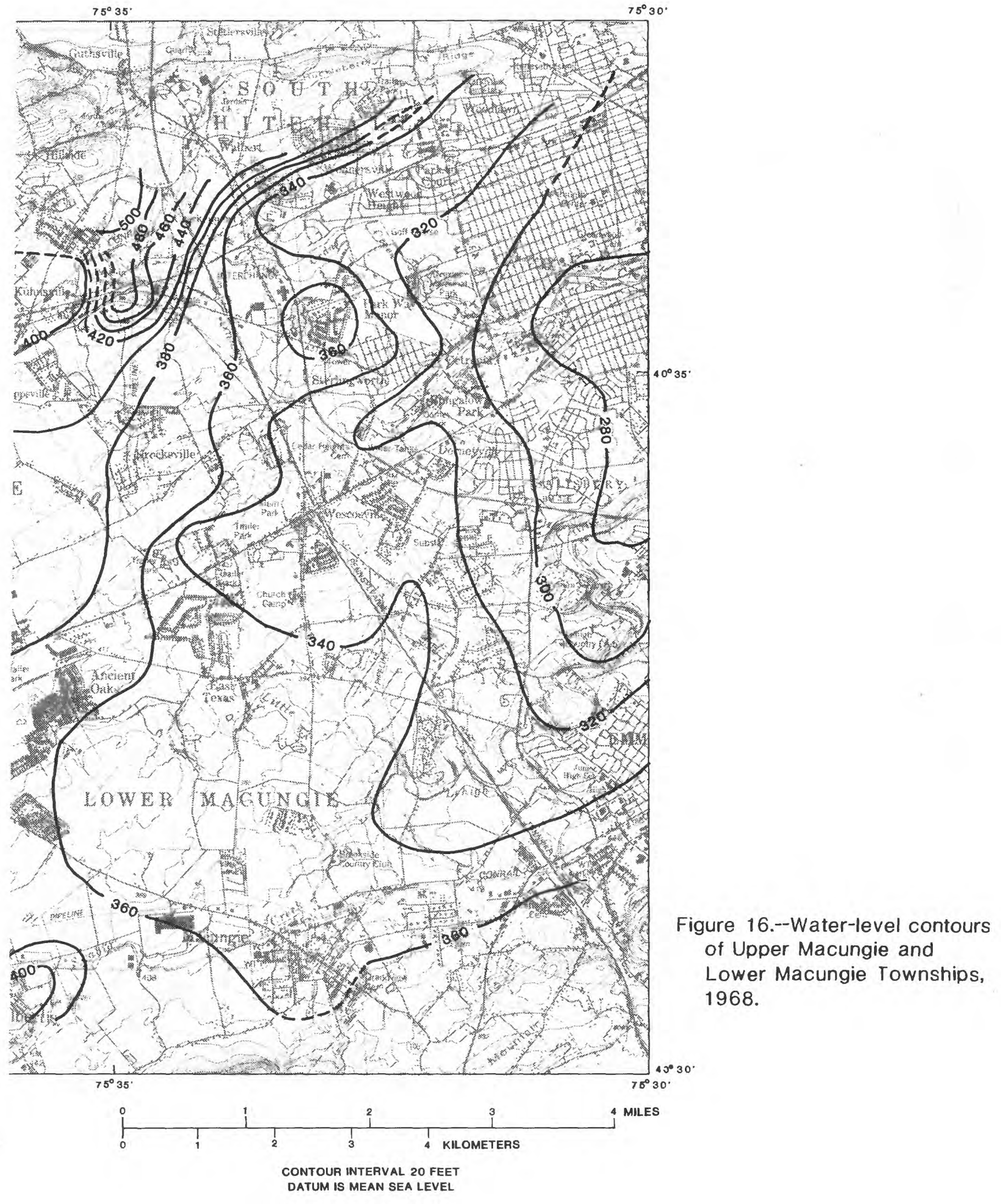




\section{Discretization}

Ground-water and surface-water divides do not coincide in the Lehigh Valley; therefore, the area between the Lehigh River and Sacony Creek was modeled to include the natural hydrologic boundaries of the ground-water-flow system. The modeled area was discretized intola rectangular grid of 29 rows and 45 columns containing 861 active cells (fig. 17). The cell location notation used in this report is (row, column). For example, $(6,35)$ denotes a cell in the 6 th row and 35th column of the model grid. Cells are 2,000 ft on each side, except for columns 2, 3, and 4, which are 2,000 ft by 4,000, 4,000 , and $3,000 \mathrm{ft}$, respectively. The total area covered by active cells is $134 \mathrm{mi}^{2}$. The carbonate rocks of the Little Lehigh Creek basin are represented by 651 active cells and have an area of $93.4 \mathrm{mi}^{2}$. The modeled area of the Little Lehigh Creek basin above gaging station 01451500 is $58.9 \mathrm{mi}^{2}$, the Cedar Creek basin is $14.6 \mathrm{mi}^{2}$, and the Jordan Creek basin is $18.5 \mathrm{mi}^{2}$. The carbonate rocks of the Coplay Creek basin are represented by 112 active cells and have an area of $16.1 \mathrm{mi}^{2}$. The carbonate rocks of the Sacony Creek basin are represented by 63 active cells and have an area of $12.9 \mathrm{mi}^{2}$. The model grid is oriented parallel to the major direction of ground-water flow, which is generally parallel to geologic contacts. Physical and hydraulic properties are averaged over the area represented by each cell and are assigned to a node in the center of the cell.

\section{Boundary Conditions}

The modeled area is defined by a set of boundary conditions. Three types of boundary conditions are used: (1) specified flux, (2) head dependent, and (3) specified head. The model program sets/the conductance across the exterior faces of the cells in the first and last rows and columns of the model grid to zero; this produces a specified-flux boundary with a specified flux of zero (no-flow boundary) around the exterior cells of the grid (McDonald and Harbaugh, 1988, p. 3-14 - 3-15).

On the northwestern and southeastern sides of the modeled area, the geologic contact between the carbonate and noncarbonate rocks is a headdependent boundary. The contact is simulated using the general-head boundary package of the McDonald and Harbaugh (1988, p. 11-1) model program. A headdependent boundary consists of a source of water outside the modeled area (noncarbonate rock) that supplies water to a cell in the modeled area (carbonate rock) at a rate proportional to the head difference between the source and the cell. The rate at which water is supplied to the cell in the modeled area is

$$
Q_{h}=C_{h}\left(h_{s}-h_{a}\right) \text {, }
$$




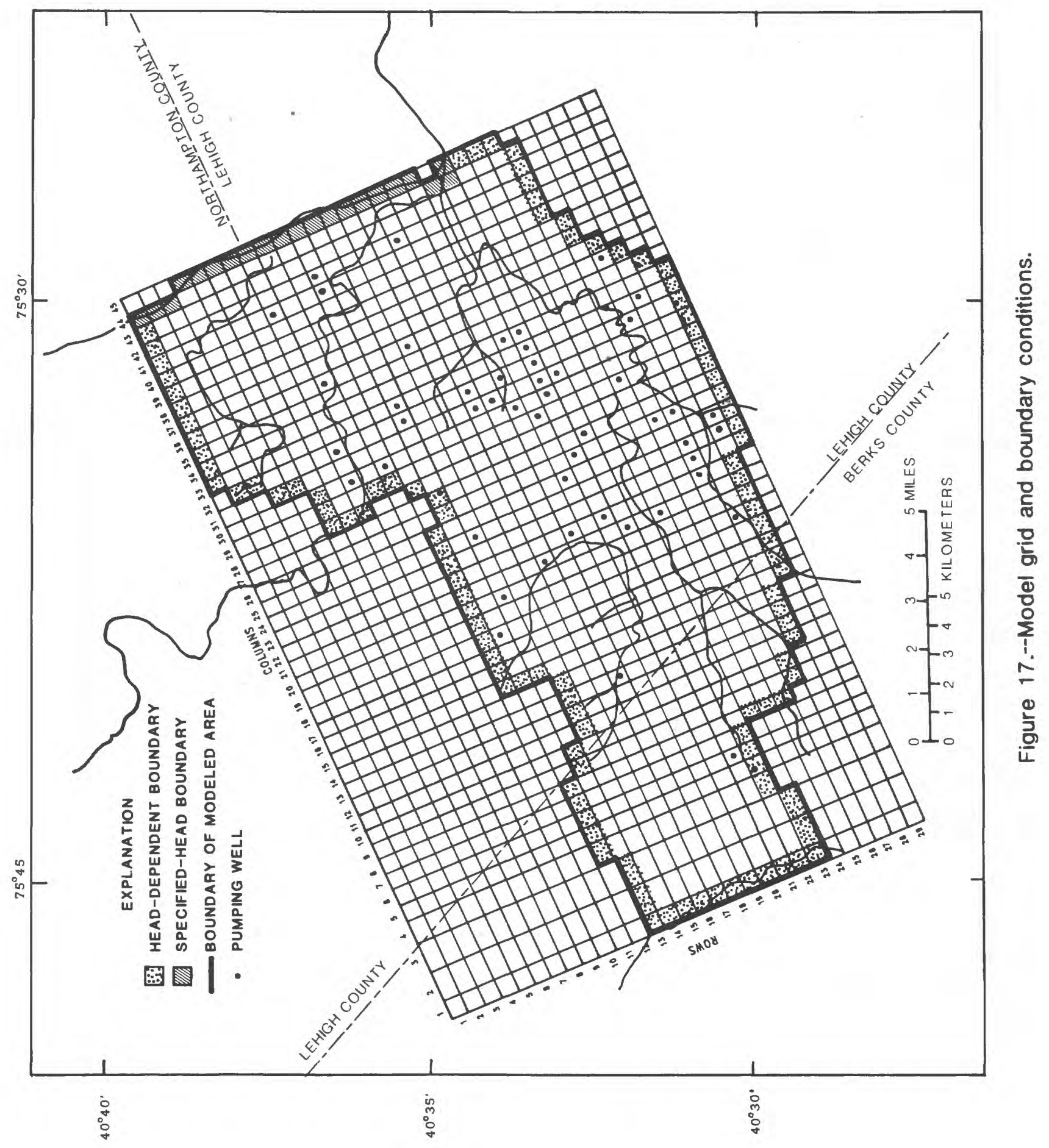


where $Q_{h}$ - rate at which water enters or leaves a block along the boundary,

$C_{h}$ - hydraulic conductance of the aquifer material between the known head in the source and the boundary of the simulated area,

$h_{s}=$ known head in the source, and

$h_{a}=$ head in the cell in the modeled area at the model boundary.

The head-dependent boundary simulates the interface between the carbonate and noncarbonate rocks. The quantity of water crossing this boundary changes as the hydraulic gradient across the boundary changes. by

The hydraulic conductance for each block along the boundary is calculated

where

$$
C_{h}=K A / L,
$$

$$
\begin{aligned}
& \mathrm{K}=\text { hydraulic conductivity, } \\
& \mathrm{A}=\text { the cross-sectional flow area, and } \\
& \mathrm{L}=\text { the flow length. }
\end{aligned}
$$

Heads in the source were taken from the 1968 water-table map (Wood and others, 1972, p1.4a) or, in some cases, estimated. Hydraulic conductivity of the aquifer material between the head in the source area and model boundary was estimated. Estimates of hydraulic conductivity are discussed in the next section.

On the northeastern side of the modeled area, the Lehigh River is simulated as a specified-head (constant-head) boundary. The Lehigh River is a regional sink, and ground water discharges to the Lehigh River from the Lehigh Valley (Wood and others, 1972, p1. 4a).

On the southwestern side, the boundary is Sacony Creek, which is represented by a head-dependent boundary (stream cells). All streams are simulated as head-dependent boundaries. Leakage to streams (McDonald and Harbaugh, 1988, p. 6-5) is approximated by

where

$$
Q_{r}=k^{\prime} L W\left(h_{r}-h_{a}\right) / m \text {, }
$$

$$
\begin{aligned}
& Q_{r}=\text { leakage, } \\
& k^{\prime}=\text { streambed hydraulic conductivity, } \\
& L=\text { length of stream reach, } \\
& W=\text { width of stream, } \\
& h_{r}=\text { stream stage, } \\
& h_{a}=\text { head in the aquifer, and } \\
& m=\text { streambed thickness. }
\end{aligned}
$$


The model lower boundary is a specified-flux (no-flow) boundary $600 \mathrm{ft}$ below land surface. No ground-water flow crosses this boundary. The model upper boundary is represented by the water-table surface, streams, and springs. The water-table is a specified flux boundary; the flux is areal recharge. Stream cells are shown on figure 18. Schantz and Crystal Springs are simulated as drains (McDonald and Harbaugh, 1988, p. 9-3). Discharge from Schantz and Crystal Springs is calculated by

$$
Q_{d}=C_{d}\left(h_{a}-h_{d}\right) \text {, }
$$

where

$$
\begin{aligned}
& Q_{d}=\text { rate at which water flows into the drain, } \\
& C_{d}=\text { hydraulic conductance of the interface between } \\
& \text { the aquifer and the spring, } \\
& h_{a}=\text { head in the aquifer near the spring, and } \\
& h_{d}=\text { elevation of the spring. }
\end{aligned}
$$

\section{Model Calibration}

The ground-water-flow model of the Little Lehigh Creek basin was calibrated under steady-state conditions using average recharge, evapotranspiration, and pumping rates. The criteria used to determine when the steady-state model was calibrated included simulation of: (1) the average water budget for the Little Lehigh Creek basin above gaging station 01451500 , (2) the average base flow of Little Lehigh Creek, (3) the underflow from the Little Lehigh Creek basin above gaging station 01451500 to the Cedar Creek basin, (4) head in the carbonate rocks of the Little Lehigh Creek basin, (5) regional ground-water flow, and (6) average discharge of Schantz and crystal springs. The model was considered calibrated when all of these criteria were met.

The recharge rate was based on the 1975-83 average recharge rate (table 12). A recharge rate of $4.97 \times 10^{-3} \mathrm{ft} / \mathrm{d}$ (feet per day) (21.75 in/yr) was used for model simulations. Recharge from precipitation is evenly distributed over the area.

The maximum ground-water evapotranspiration (ET) rate, $4.59 \times 10^{-3} \mathrm{ft} / \mathrm{d}$ (20.09 in/yr), was based on the 1975-83 average water budget (table 10). This rate is equal to about 70 percent of the pan evaporation rate for southeastern Pennsylvania. Ground-water ET determined by the model depends on the position of the head in the aquifer relative to two given ET reference elevations--ET surface and ET extinction depth (McDonald and Harbaugh, 1988, p. 10-1). At and above the ET surface, the ground-water ET rate is the maximum ground-water ET rate. At and below the ET extinction depth, the ground-water ET rate is zero. The ground-water ET rate varies linearly from the maximum ground-water ET rate at the ET surface to zero at the ET extinction depth. The ET surface was set to the average land-surface elevation for each cell. The ET extinction depth was set to $10 \mathrm{ft}$. 


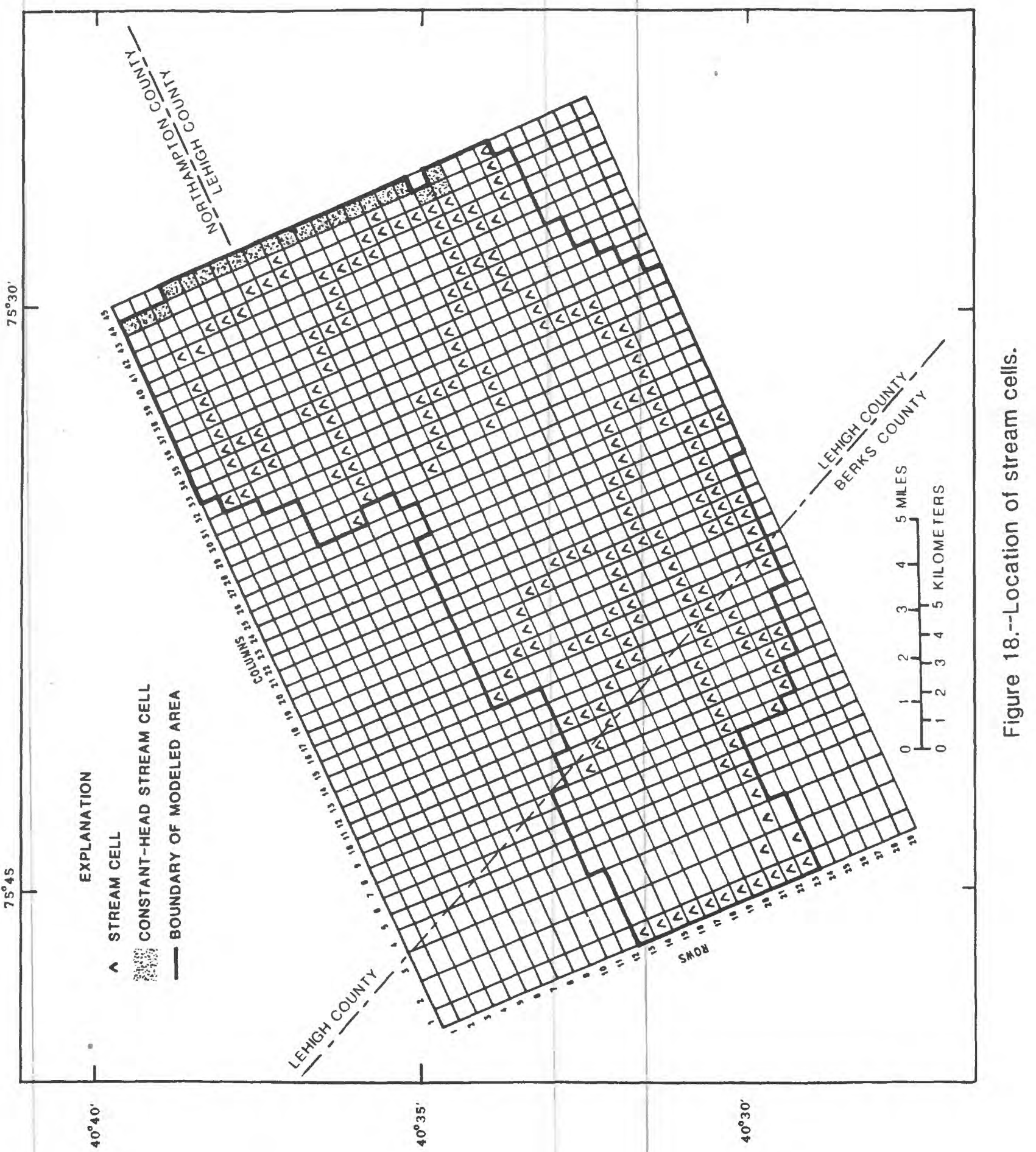




\section{Aquifer characteristics}

Aquifer characteristics required by the model include altitude of the top and bottom of the aquifer, aquifer thickness, aquifer horizontal hydraulic conductivity, aquifer anisotropy, drain (spring) hydraulic conductance ${ }^{1}$, drain (spring) elevation, and streambed vertical hydraulic conductance.

The top of the aquifer is the land surface. Average land-surface elevation for each cell was determined from 7.5-minute topographic maps.

Aquifer thickness was assumed to be $600 \mathrm{ft}$ for model simulations on the basis of analysis of water-bearing zones. Few water-bearing zones are penetrated below a depth of $600 \mathrm{ft}$ ( table 3), and ground-water circulation below a depth of $600 \mathrm{ft}$ is considered negligible. The altitude of the bottom of the aquifer for each cell was set at $600 \mathrm{ft}$ below the average land-surface elevation for that cell.

Each geologic unit was assigned a different hydraulic conductivity. If a cell contained two geologic units of nearly equal area, the mean hydraulic conductivity of the two units was used; otherwise, the hydraulic conductivity of the predominant unit was assigned to the cell.

Initial aquifer hydraulic conductivity was estimated from specificcapacity data. Transmissivity was estimated from specific capacity using Theis's method for a water-table aquifer (Theis, 1963, p. 332-336):

and

$$
\mathrm{T}^{\prime}=0.134(\mathrm{Q} / \mathrm{s})\left(\mathrm{k}-264 \log _{10} 5 \mathrm{Sy}+264 \log _{10} t\right) \text {, }
$$

$$
k=-66-264 \log _{10}\left(3.74 r^{2} \times 10-6\right) \text {, }
$$

where

$$
\begin{aligned}
& \mathrm{T}^{\prime}=\text { estimated transmissivity }\left(\mathrm{ft}^{2} / \mathrm{d}\right), \\
& \mathrm{Q}=\text { pumping rate }(\mathrm{gal} / \mathrm{min}), \\
& \mathrm{s}=\text { drawdown }(\mathrm{ft}) \\
& \mathrm{Sy}=\text { specific yield, } \\
& \mathrm{t}=\text { duration of pumping }(\mathrm{d}), \\
& \mathrm{k}=\text { a constant, and } \\
& \mathrm{r}=\text { well radius (ft). }
\end{aligned}
$$

Because the wells used for analysis have small diameters and tap consolidated rock, $x$ was set equal to well radius (Theis, 1963, p. 335). A specific yield of 0.05 , the average used to calculate change in ground-water storage in the water budgets (table 10), was assumed. Hydraulic conductivity was calculated by dividing transmissivity by the depth of uncased borehole (table 13).

1 Hydraulic conductance of a block of aquifer material is equal to the hydraulic conductivity of the aquifer material times the cross-sectional area of the block perpendicular to flow divided by the length of the block. 
Table 13 illustrates the variability in the hydraulic properties of carbonate rock. For example, estimates of hydraulic conductivity for the Beekmantown Group range over seven orders of magnitude. The mean and median for most units differs by an order of magnitude. Preliminary model simulations using the mean and median hydraulic conductivities gave unsatisfactory results. However, a hydraulic conductivity halfway between the mean and median gave very good results. Therefore, the average of the mean and median hydraulic conductivity was used as the initial hydraulic conductivity for model calibration (table 13). The only adjustment made to hydraulic conductivity during model calibration was to raise the hydraulic conductivity of the Allentown Dolomite from $43 \mathrm{to} 47 \mathrm{ft} / \mathrm{d}$ and the Beekmantown Group from 78 to $83 \mathrm{ft} / \mathrm{d}$ to help calibrate base flow and underflow. The hydraulic conductivity of individual cells was not adjusted. Final calibrated hydraulic conductivities are given in table 13 .

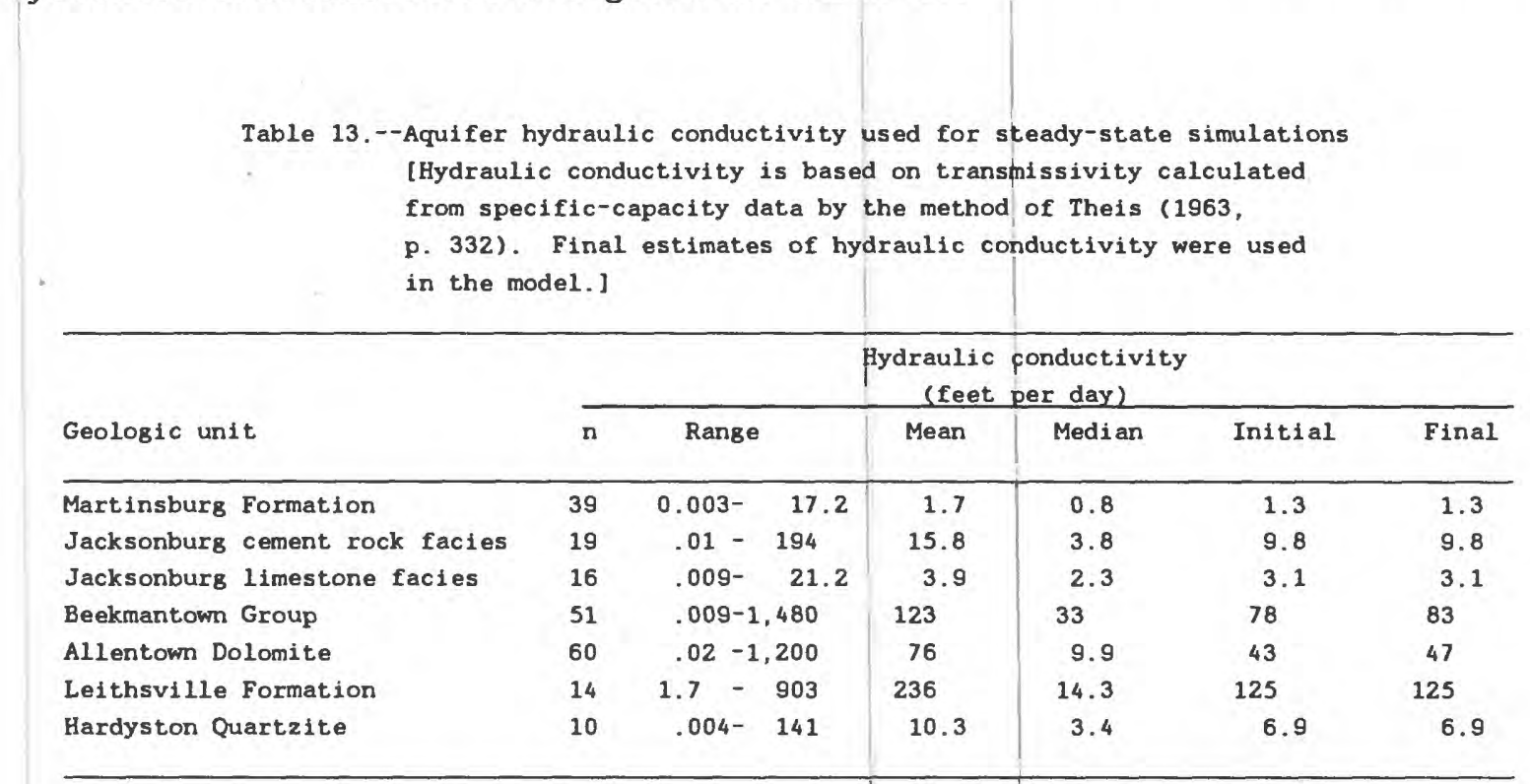

Ground-water flow in the noncarbonate rocks is local; most ground water is discharged to nearby streams draining the noncarbonate rocks. Some ground water flows from the noncarbonate rocks to adjacent carbonate rocks. On the basis of local ground-water divides in the noncarbonate rocks adjacent to the carbonate rocks, ground water flows from $4.2 \mathrm{mi}^{2}$ of the Hardyston Quartzite and $0.9 \mathrm{mi}^{2}$ of the Martinsburg Formation to carbonate rocks of the Little Lehigh Creek basin above streamflow-gaging station 01451500 . The average annual quantity of ground water flowing from the noncarbonate to the carbonate rocks is estimated as $2.58 \times 10^{8} \mathrm{ft}^{3}$ by calculating the quantity of recharge ( $21.75 \mathrm{in} / \mathrm{yr})$ on $5.1 \mathrm{mi}^{2}$ of noncarbonate rocks draining to carbonate rocks. This quantity of water is equal to $1.89 \mathrm{in} / \mathrm{yr}$ ( $7.27 \mathrm{Mgal} / \mathrm{d})$ entering the carbonate rocks above streamflow-gaging station 01451500.

Hydraulic conductance for each head-dependant boundary node at the contact between the carbonate and noncarbonate rocks was calculated using equation 10. Hydraulic conductivities were based on table 13. The flow 
length was set equal to the distance to the nearest local ground-water divide in the noncarbonate rocks. Initial estimates of hydraulic conductance produced too much inflow to the carbonate rocks and were reduced. Hydraulic conductance assigned to nodes along the northwestern model boundary (headdependent boundary) at the contact between the carbonate rocks and the Martinsburg Formation ranged from 41 to $514 \mathrm{ft}^{2} / \mathrm{d}$. Hydraulic conductance assigned to nodes along the southeastern model boundary (head-dependent boundary) at the contact between the carbonate rocks and the Hardyston Quartzite ranged from 34 to $1,802 \mathrm{ft}^{2} / \mathrm{d}$. Simulated inflow to the carbonate rocks using these hydraulic conductances is $2.02 \mathrm{in} / \mathrm{yr}$.

Schantz and Crystal Springs are simulated as drains using equation 12. These spring systems are complex and not well understood. They are poorly simulated as drains, although the drain package of the McDonald and Harbaugh (1988) model program is the most suitable method for simulating springs. Simulations using the actual drain elevations produced discharges less than the 1975-83 average discharges. In order to simulate the hydrologic system, a volume of water equal to the 1975-83 average spring discharge had to discharge from the aquifer at the spring cells. Therefore, drain conductance and drain elevation were adjusted to simulate 1975-83 average spring discharges of $7.4 \mathrm{Mgal} / \mathrm{d}$ for Schantz Spring and $4.0 \mathrm{Mgal} / \mathrm{d}$ for Crystal Spring. Drain conductances of $80,000 \mathrm{ft} / \mathrm{d}$ and $71,000 \mathrm{ft} / \mathrm{d}$ were assigned to Schantz and Crystal Springs, respectively. Spring elevations were set to $312 \mathrm{ft}$ for Schantz Spring and $250 \mathrm{ft}$ for Crystal Spring.

The water-table aquifer system is considered to be horizontally isotropic. Analysis of aquifer-test data from wells LE-1319 and LE-1355 did not show a preferential direction of transmissivity. The model grid is oriented parallel to strike. A column-to-row anisotropy multiplication factor of 1.0 was used, so that hydraulic conductivity along strike was equal to hydraulic conductivity across strike.

The ground-water and surface-water systems in the Little Lehigh Creek basin are well connected, and water moves freely between the two systems. The direction and rate of water movement between the two systems is controlled by the vertical hydraulic conductivity of the streambed material, thickness of streambed material, and the difference between head in the aquifer and stream stage. Streambed material differs greatly from place to place and consists of gravel, sand, and(or) clay. The vertical hydraulic conductivity of the streambed materials is highly variable and is not known. Therefore, a streambed hydraulic conductance of $10,000 \mathrm{ft} / \mathrm{d}$ was assigned to all stream cells. Streambed thickness was assumed to be $1 \mathrm{ft}$. 


\section{Pumping rates}

Average 1975-83 pumpage from the modeled area is $7.55 \mathrm{Mgal} / \mathrm{d}$. Pumpage from the Little Lehigh Creek basin above streamflow-gaging station 01451500 is $5.04 \mathrm{Mgal} / \mathrm{d}$, which is 67 percent of the pumpage in the modeled area. Pumpage includes all municipal and private water purveyors and major industrial users of ground water. Pumpage from domestic and commercial wells is not included. Figure 19 shows the annual ground-water pumpage from the Little Lehigh Creek basin above streamflow-gaging station 01451500 and the modeled area for 197583. Ground-water pumpage data prior to 1975 generally are not available. Ground-water pumpage increased only slightly from 1976-82. Pumping rates (table 14) used in model simulations are 1975-83 average rates.

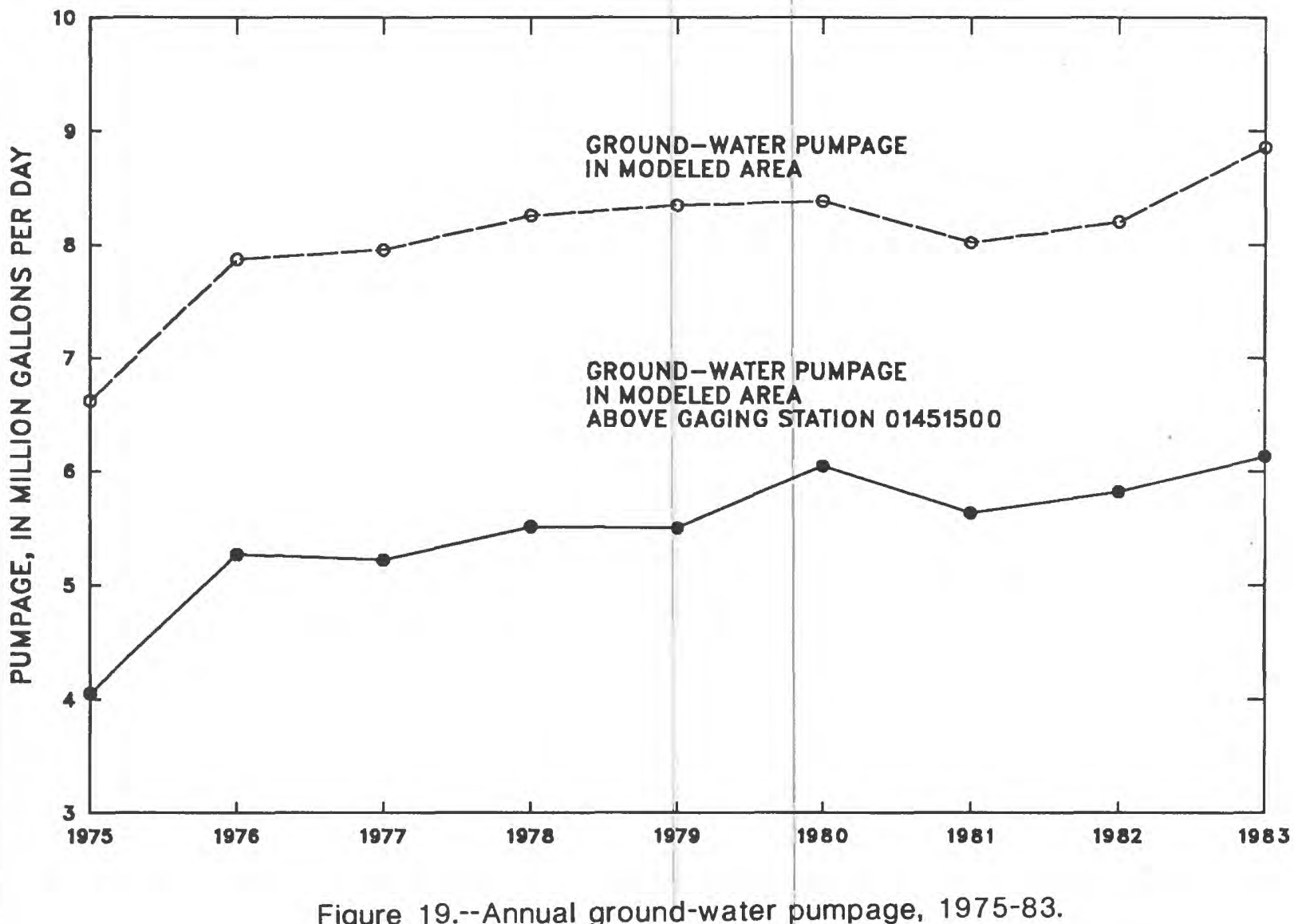

Figure 19.--Annual ground-water pumpage, 1975-83. 
Table 14.--Pumping rates used for model simulations

[Mgal/yr, million gallons per year]

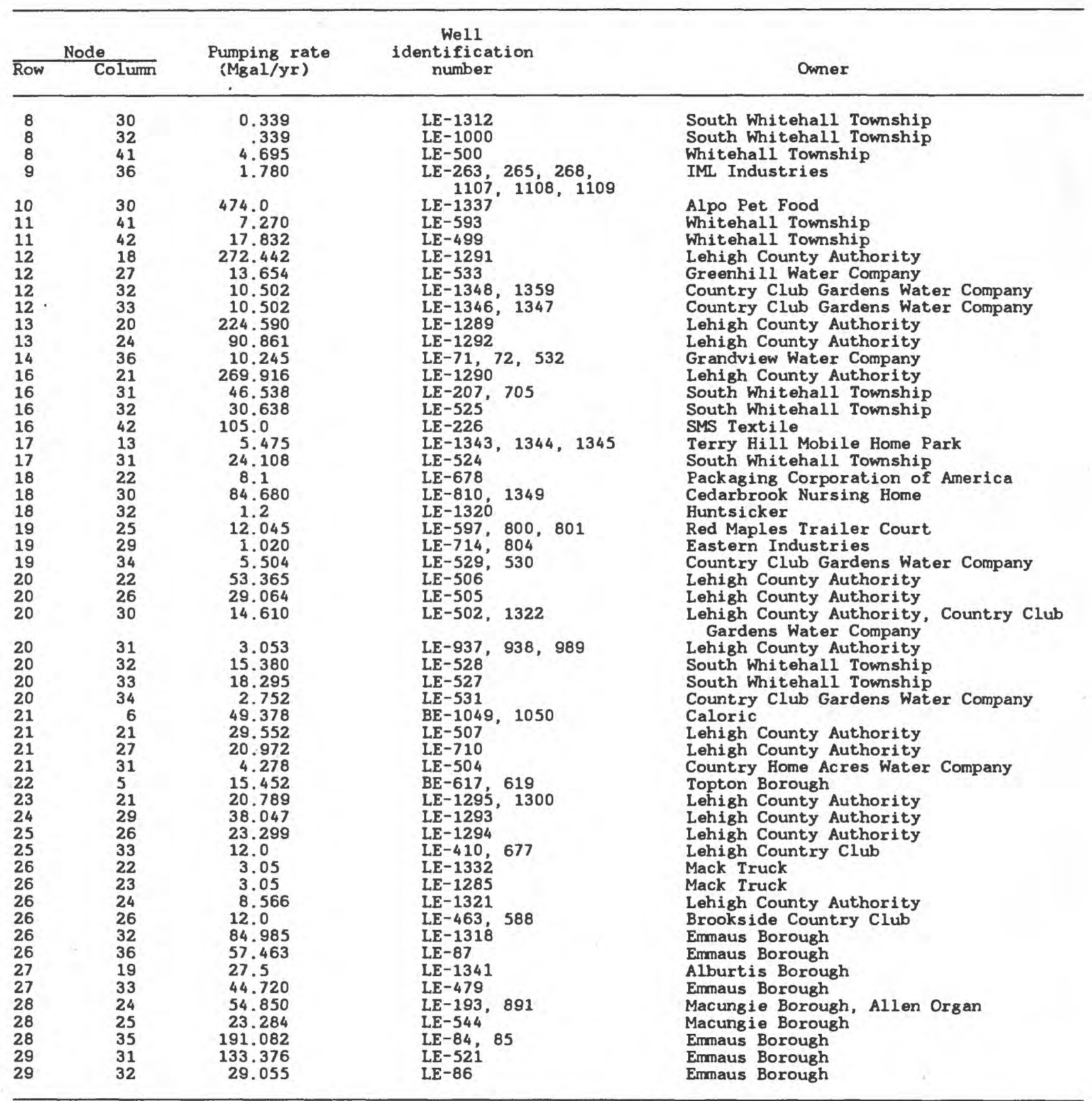




\section{Simulated water-table surface}

The 1975-83 average simulated water-table surface in the Little Lehigh Creek basin (fig. 20) was compared to the observed water-table surface for 1984 (fig. 9). The observed water-table surface was mapped using $20-f t$ contours. Simulated heads in the carbonate rocks of the Little Lehigh Creek basin were compared with observed heads using the root mean square error (RMSE) difference between observed and simulated heads. The RMSE is the square root of the sum of the squared difference between the observed and simulated head divided by the number of heads and was calculated using the following equation:

$$
\text { RMSE }=\sqrt{\frac{\sum\left(h_{o}-h_{p}\right)^{2}}{n}}
$$

where

$$
\begin{aligned}
& h_{0}=\text { observed head, } \\
& h_{p}=\text { simulated head, and } \\
& n=\text { number of cells. }
\end{aligned}
$$

For steady-state calibration, an RMSE of $21.19 \mathrm{ft}$ was obtained for 316 cells in the Little Lehigh Creek basin. The average difference between simulated and observed head (absolute values) is $14 \mathrm{ft}$. Simulated heads generally are a little higher than observed heads.

The model-simulated water-table surface (fig. 20) reproduces the observed water-table surface poorly because (1) the simulated head is the average head simulated over a $0.25-\mathrm{mi}^{2}$ block of the aquifer rather than the head at a discrete point; and (2) a density of four simulated water-table-surface altitude points per square mile, with the water-table surface elevation at the center of each node, provides insufficient resolution.

\section{Simulated average water budget}

The average (1975-83) water budget for the Little Lehigh Creek basin was approximated by a steady-state simulation. The simulated water budget is compared to the calculated water budget in table 15. The calculated base flow in table 15 is the 1975-83 average base flow (table 12). The model simulates base flow only from the carbonate rocks; however, base flow measured at gaging station 01451500 on Little Lehigh Creek includes base flow from both the carbonate and noncarbonate rocks. Base flow contributed by noncarbonate rocks in the basin was measured during July 1989. Fourteen streams were measured at the boundary of the modeled area. Total base flow contributed to the modeled area by the noncarbonate rocks was $20.2 \mathrm{ft}^{3} / \mathrm{s}$; the flow of Little Lehigh Creek at gaging station 01451500 was $102.5 \mathrm{ft}^{3} / \mathrm{s}$. Therefore, noncarbonate rocks contributed 20 percent of the base flow measured at the gaging station. The flow at the gaging station was 17 percent higher than the 1975-83 average base flow $\left(87.6 \mathrm{ft}^{3} / \mathrm{s}\right)$. Base-flow contribution from the noncarbonate rocks is assumed to be 20 percent of base flow measured at the gaging station. The 1975-83 average base flow from the carbonate rocks was, therefore, estimated 
to be 20 percent of 14.78 in. $\left(87.6 \mathrm{ft}^{3} / \mathrm{s}\right)$ or $11.82 \mathrm{in.}(70.1 \mathrm{ft} / \mathrm{s})$; the estimated contribution from the noncarbonate rocks is $2.96 \mathrm{in}$. $(17.5 \mathrm{ft} / \mathrm{s})$. The simulated base flow from the carbonate rocks is $11.85 \mathrm{in.}\left(70.2 \mathrm{ft}^{3} / \mathrm{s}\right)$. Simulated base flow from the carbonate rocks $\left(70.2 \mathrm{ft}^{3} / \mathrm{s}\right)$ plus estimated base flow from the noncarbonate rocks $\left(17.5 \mathrm{ft}^{3} / \mathrm{s}\right)$ is equal to the $87.7 \mathrm{ft}^{3} / \mathrm{s}$ simulated base flow from the Little Lehigh Creek basin above gaging station 01451500 in table 15.

Table 15 lists the simulated net ground-water underflow beneath the surface-water divide on the eastern side of the Little Lehigh Creek basin. Simulated underflow is $4.04 \mathrm{in.}(15.54 \mathrm{Mgal} / \mathrm{d})$ out of the basin, which is nearly equal to the estimated underflow of $4.00 \mathrm{in.}(15.39 \mathrm{Mgal} / \mathrm{d})$. The model also simulates $0.1 \mathrm{in} / \mathrm{yr}(0.38 \mathrm{Mgal} / \mathrm{d})$ of inflow from the Sacony Creek basin to the west.

Simulated ground-water ET ( $0.63 \mathrm{in} / \mathrm{yr})$ is less than estimated groundwater ET ( $1.5 \mathrm{in/yr}$ ). The quantity of simulated ground-water ET can be increased by raising the maximum ET rate or lowering the ET extinction depth; however, the values used for these variables to produce $1.5 \mathrm{in} / \mathrm{yr}$ of ET would be unreasonable.

Table 15.--Simulated average water budget for the Little Lehigh Creek basin and simulated spring discharge

[in/yr, inches per year; $\mathrm{ft}^{3} / \mathrm{s}$, cubic feet per second; Mgal/d, million gallons per day]

\begin{tabular}{|c|c|c|c|c|c|c|}
\hline Water budget & \multicolumn{2}{|r|}{ Calculated } & \multicolumn{4}{|c|}{ Simulated } \\
\hline Recharge & 21.75 & in/yr & 21.75 & in/yr & & \\
\hline Base flow & 87.6 & $\mathrm{ft}^{3} / \mathrm{s}(14.78 \mathrm{in} / \mathrm{yr})$ & 87.7 & $\mathrm{ft}^{3} / \mathrm{s}$ & $(14.80$ & in $/ \mathrm{yr}$ ) \\
\hline Ground-water evapotranspiration & 1.50 & in/yr & .63 & in $/ y r$ & & \\
\hline Ground-water withdrawals & 5.04 & $\mathrm{Mgal} / \mathrm{d}(1.31 \mathrm{in} / \mathrm{yr})$ & 5.04 & Mgal/d & $(1.31$ & in $/$ yr) \\
\hline Underflow out of basin to west & 15.39 & $\mathrm{Mgal} / \mathrm{d}(4.00 \mathrm{in} / \mathrm{yr})$ & 15.54 & $\mathrm{Mgal} / \mathrm{d}$ & $(4.04$ & in $/ y r)$ \\
\hline Underflow into basin from west & 0.0 & $\mathrm{Mgal} / \mathrm{d}(0.0 \mathrm{in} / \mathrm{yx})$ & .38 & Mgal/d & $(.10$ & in $/ y r)$ \\
\hline Inflow from noncarbonate rocks & 7.27 & $\mathrm{Mgal} / \mathrm{d}(1.89 \mathrm{in} / \mathrm{yr})$ & 7.77 & $\mathrm{Mgal} / \mathrm{d}$ & $(2.02$ & in/yr) \\
\hline \multicolumn{7}{|l|}{ Spring discharge } \\
\hline Schantz Spring discharge & 7.4 & $\mathrm{Mgal} / \mathrm{d}$ & 7.4 & $\mathrm{Mgal} / \mathrm{d}$ & & \\
\hline Crystal Spring discharge & 4.0 & $\mathrm{Mgal} / \mathrm{d}$ & 4.0 & $\mathrm{Mgal} / \mathrm{d}$ & & \\
\hline
\end{tabular}









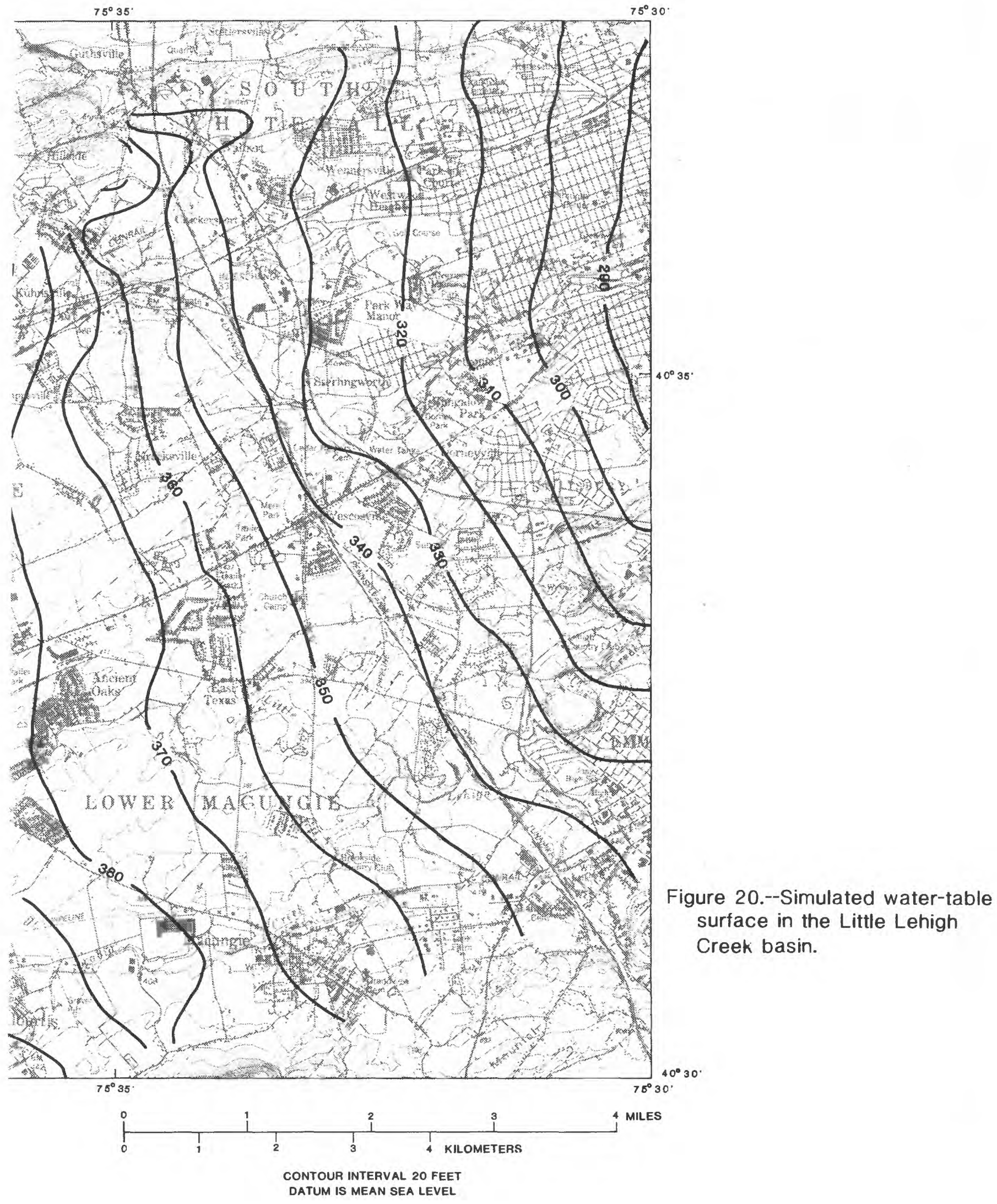


A sensitivity analysis of model variables involves varying the value of a single model variable while holding the others constant. The effect of varying the value of a particular model variable on the simulated water budget and head was determined by varying the value of the variable being tested over a reasonable range, while the values of the other variables remained fixed. Then, any changes in the simulated water budget or head are caused only by the change in the value of the variable being tested. If the changes in the value of a variable causes a relatively large change in the simulated water budget or head, the model is said to be sensitive to that variable. Conversely, if changes in the simulated water budget or head are relatively slight, the model is considered to be insensitive to that variable. In this report, the model is considered as being very sensitive, moderately sensitive, and insensitive to changes in the value of model variables; degree of sensitivity is relative.

The variables tested for sensitivity are aquifer hydraulic conductivity, aquifer thickness, streambed hydraulic conductance, recharge rate, groundwater evapotranspiration rate, evapotranspiration extinction depth, headdependent boundary hydraulic conductance, and head in the source supplying water to head-dependent boundary cells. The results of a final sensitivity analysis, made when model calibration was completed, are presented below. The value of model variables was varied over a range from half to double the calibrated value; the head in the source supplying water to head-dependent boundary cells was raised and lowered $50 \mathrm{ft}$. The effects of changing the value of a model variable on base flow from the carbonate rocks are shown on figures 21 and 22. The effects of changing the value of a model variable on the RMSE between observed and simulated head are shown on figures 23 and 24. On figures 21 and 22, slope is directly proportional to sensitivity. A low slope indicates low sensitivity (or insensitivity); a high slope indicates high sensitivity.

The model was found to be very sepsitive to the recharge rate (figs. 21 and 23). When the recharge rate was varied from half to double the 1975-83 average rate $(10.88$ to 43.50 in/yr), the simulated base flow from the carbonate rocks ranged from 32.8 to $153 \mathrm{ft}^{3} / \mathrm{s}$ ( 53 percent less to 118 percent greater than the 1975-83 average base flow of $70.2 \mathrm{ft}^{3} / \mathrm{s}$ ). The RMSE ranged from 20.44 to $26.12 \mathrm{ft}$.

The model was moderately sensitive to aquifer hydraulic conductivity, aquifer thickness, streambed hydraulic conductance, and head in the source supplying water to head-dependent boundary cells. When aquifer hydraulic conductivity was varied from half to double the calibrated values, the simulated base flow ranged from 53.8 to $79.7 \mathrm{ft}^{3} / \mathrm{s}$ (23 percent less to 14 percent greater than the 1975-83 average base flow of $70.2 \mathrm{ft}^{3} / \mathrm{s}$ ). The RMSE ranged from 19.27 to $24.87 \mathrm{ft}$. When aquifer thickness was varied from 300 to $1,200 \mathrm{ft}$, the simulated base flow ranged from 51.1 to $80.4 \mathrm{ft}^{3} / \mathrm{s}$ (27 percent less to 15 percent greater than the 1975-83 average base flow). The RMSE ranged from 19.08 to $25.48 \mathrm{ft}$. When the streambed hydraulic conductance was varied from half to double the calibrated value $\left(5,000\right.$ to $\left.20,000 \mathrm{ft}^{2} / \mathrm{d}\right)$, the simulated base flow ranged from 61.6 to $79.7 \mathrm{ft}^{3} / \mathrm{s}$ (12 percent less to 14 percent greater than the 1975-83 average base flow). The RMSE ranged from 21.00 to $22.18 \mathrm{ft}$. When head in the source supplying water to head-dependent 
boundary cells was raised and lowered $50 \mathrm{ft}$ (figs. 22 and 24 ), the simulated base flow ranged from 63.7 to $80 \mathrm{ft}^{3} / \mathrm{s}$ (14 percent less to 9 percent greater than the 1975-83 average base flow of $70.2 \mathrm{ft}^{3} / \mathrm{s}$ ). The RMSE ranged from 20.70 to $21.41 \mathrm{ft}$. The inflow from the noncarbonate rocks to the carbonate rocks ranged from 1.77 to $16.12 \mathrm{Mgal} / \mathrm{d}$ (77 percent less to 108 percent greater than the estimated $7.77 \mathrm{Mgal} / \mathrm{d}$ inflow).

The model was insensitive to the ground-water evapotranspiration rate and evapotranspiration extinction depth over the range tested and the headdependent boundary hydraulic conductance over most of the range tested (figs. 21 and 23). When the ground-water evapotranspiration rate was varied from half to double the $1975-83$ average rate (10.05 to $40.18 \mathrm{in} / \mathrm{yr}$ ), the simulated base flow ranged from 69.4 to $70.5 \mathrm{ft}^{3} / \mathrm{s}$ ( 1.2 percent less to 0.3 percent greater than the 1975-83 average base flow of $\left.70.2 \mathrm{ft}^{3} / \mathrm{s}\right)$. The RMSE ranged from 21.14 to $21.19 \mathrm{ft}$. Simulated ground-water evapotranspiration ranged from 0.32 to $1.21 \mathrm{in} / \mathrm{yr}$. When the evapotranspiration extinction depth was varied from half to double ( 5 to $20 \mathrm{ft}$ ), the simulated base flow ranged from 69.9 to $70.4 \mathrm{ft}^{3} / \mathrm{s}$ ( 0.5 percent less to 0.3 percent greater than the $1975-83$ average base flow of $\left.70.2 \mathrm{ft}^{3} / \mathrm{s}\right)$. The RMSE was $21.19 \mathrm{ft}$ for all simulations. Simulated ground-water evapotranspiration ranged from 0.36 to $1.21 \mathrm{in} / \mathrm{yr}$. When the head-dependent boundary hydraulic conductance was varied from half to double the calibrated values, the simulated base flow ranged from 68.9 to $78 \mathrm{ft}^{3} / \mathrm{s}$ ( 0.6 percent less to 11 percent greater than the 1975-83 average base flow). The RMSE ranged from 20.88 to $21.19 \mathrm{ft}$. The inflow from the noncarbonate rocks to the carbonate rocks ranged from 4.04 to $14.20 \mathrm{Mgal} / \mathrm{d}$ (48 percent less to 83 percent greater than the estimated $7.77 \mathrm{Mgal} / \mathrm{d}$ inflow).

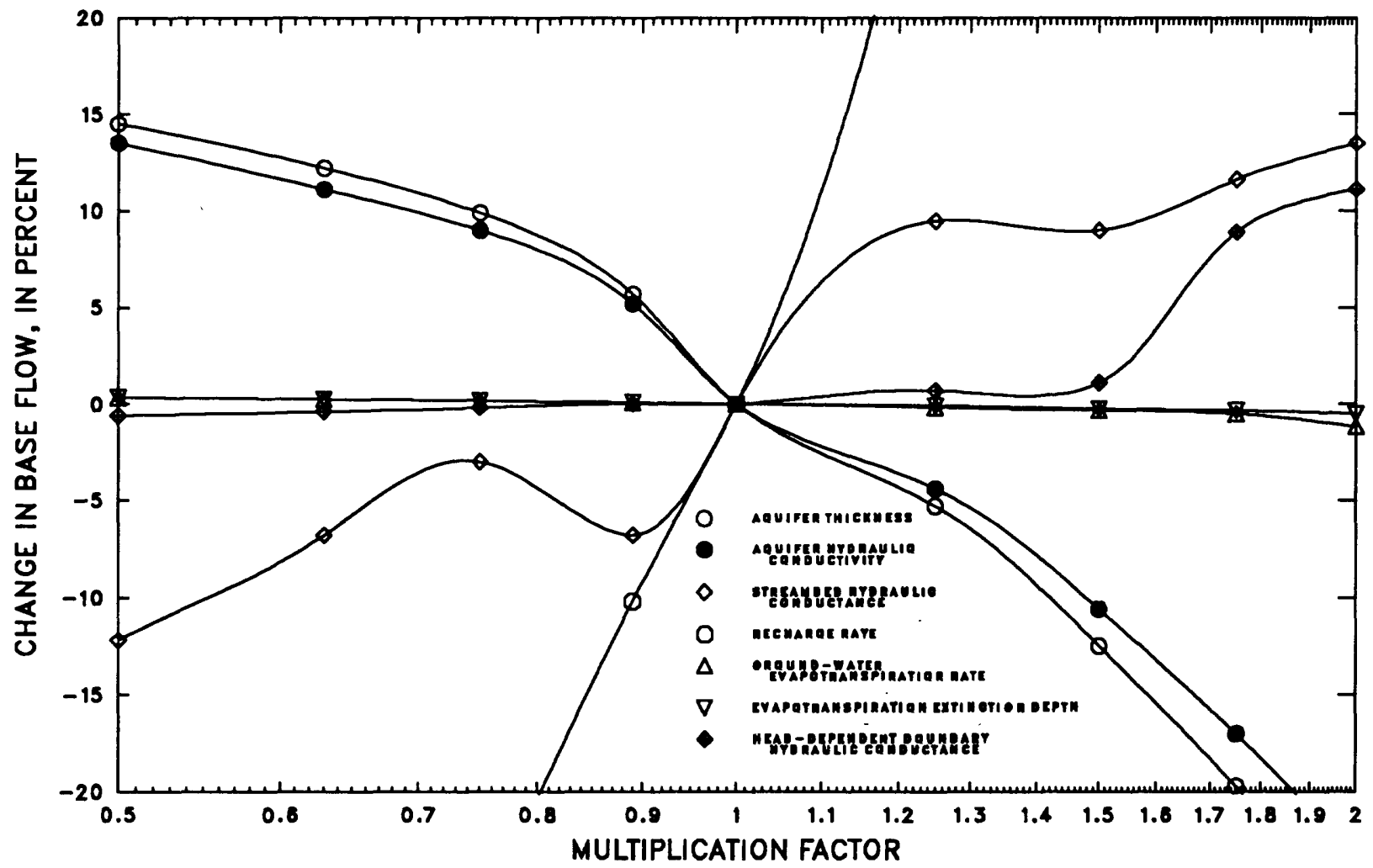

Figure 21.--Effect of varying the value of model variables on base flow. 


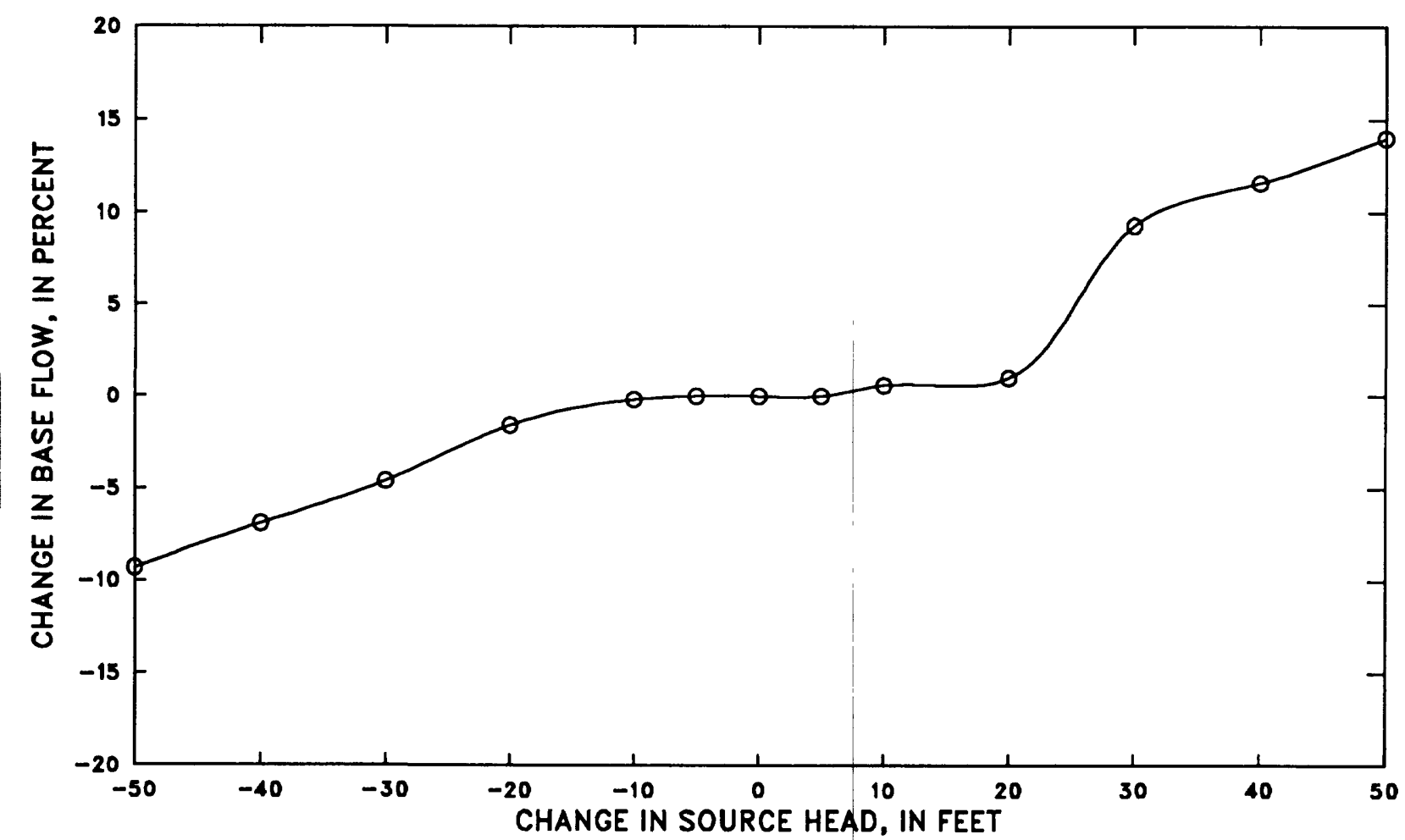

Figure 22.--Effect of varying the head in the source bed supplying water to head-dependent boundary nodes on base flow.

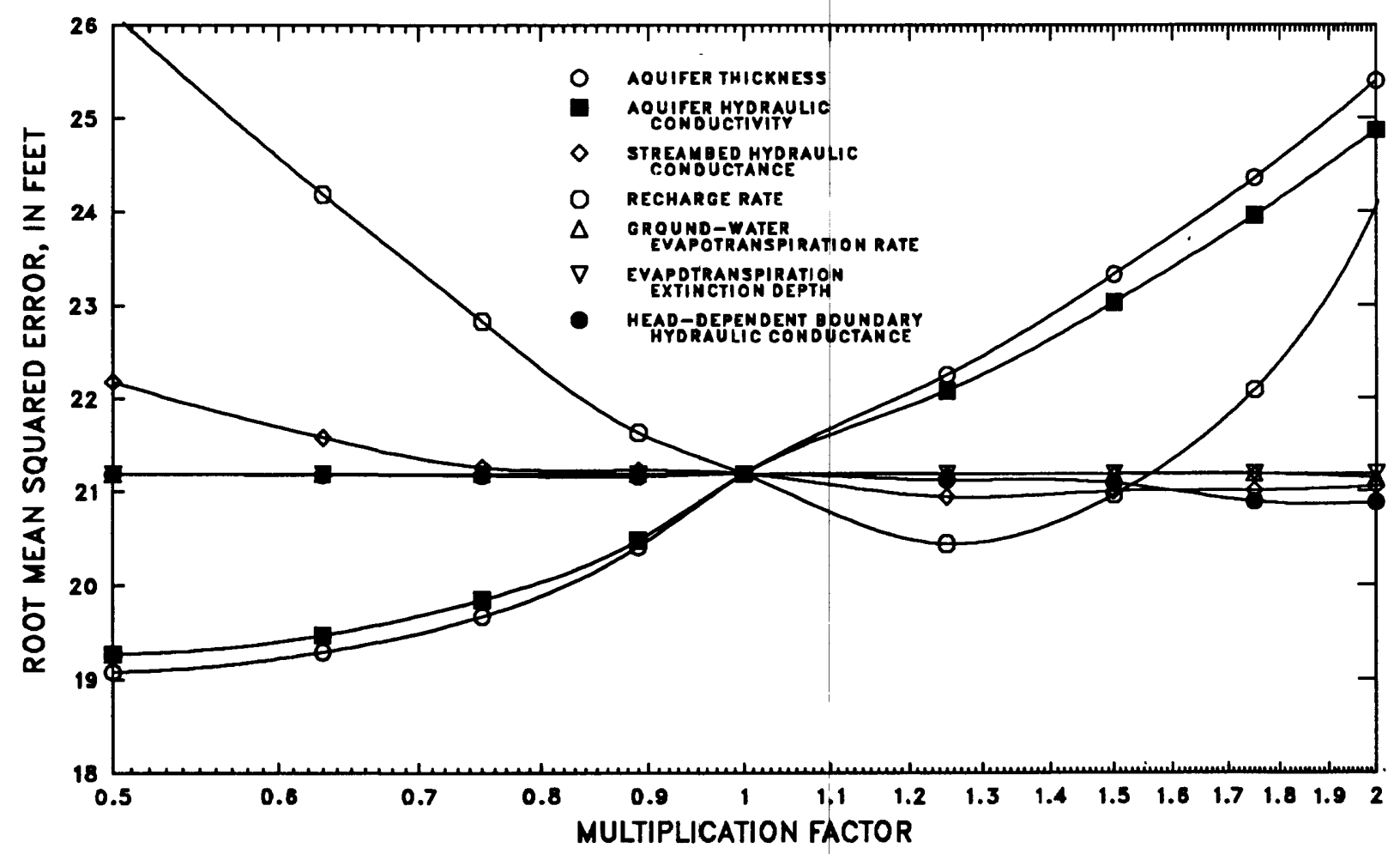

Figure 23.--Effect of varying the value of model variables on the root mean squared error between observed and simulated head. 


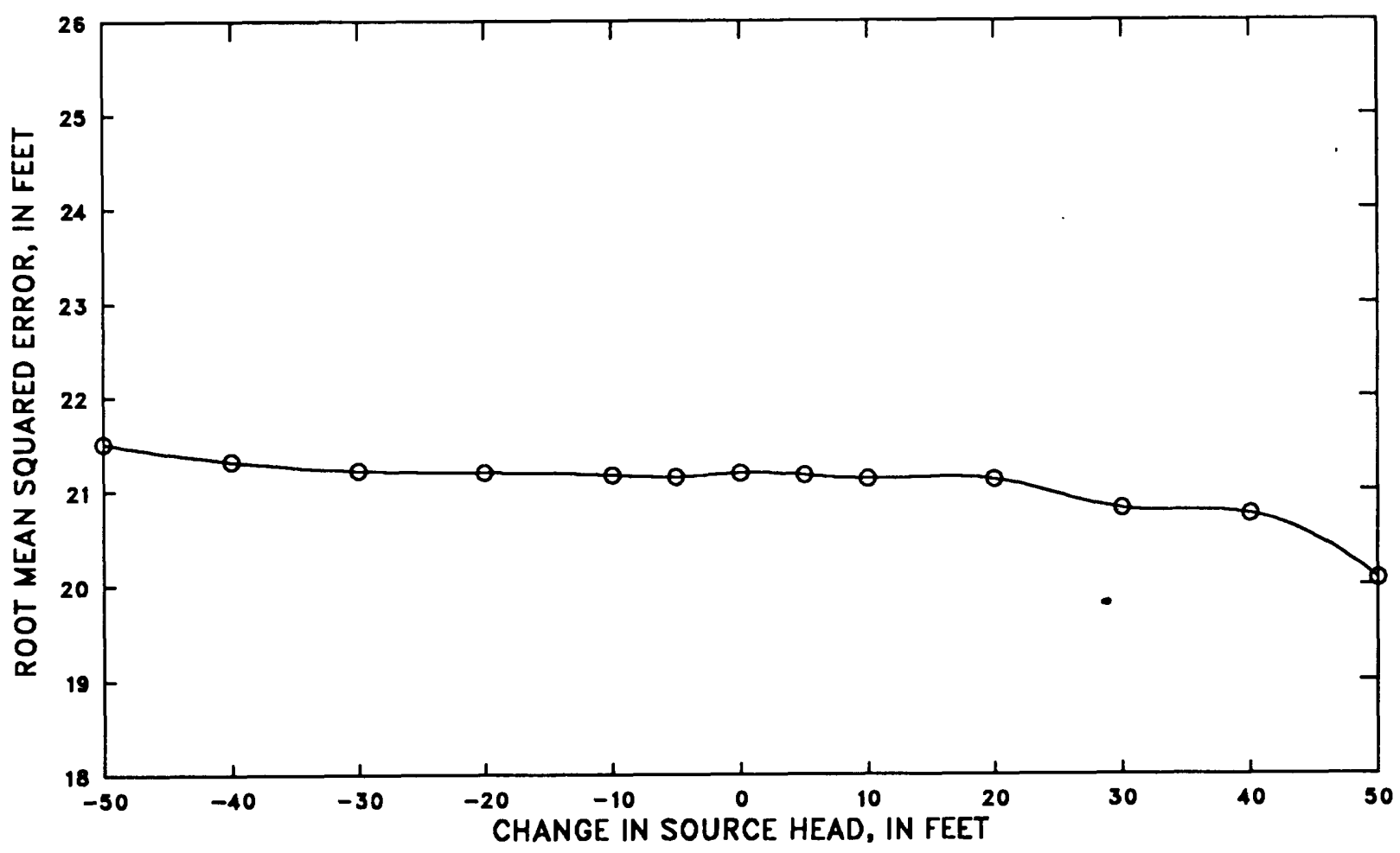

Figure 24.--Effect of varying the head in the source bed supplying water to headdependent boundary nodes on the root mean squared error between observed and simulated head.

\section{Reliability of model simulations}

The ground-water-flow model is a regional model and is considered to be calibrated for the Little Lehigh Creek basin under average conditions. It is useful for simulating the effects of stresses in the basin on the average water budget. It cannot provide estimates of site-specific effects such as head or drawdown at a particular well site or stream infiltration at a particular stream site.

Springs are poorly simulated by the model. Springs are simulated as drains rather than as outlets for a conduit system, which cannot be simulated by the model computer program. Model variables used to simulate springs were set to provide the appropriate spring discharge necessary for model simulations; they do not reflect field values. Therefore, the model cannot be used to assess the effects of stresses on spring flow.

\section{Simulated Effects of Increased Ground-Water Development}

The effects of increased ground-water development on base flow and underflow out of the Little Lehigh Creek basin above gaging station 01451500 were simulated for average and drought conditions. Increased ground-water pumping was simulated by locating a hypothetical well field in different parts of the basin. Steady-state simulations were used to represent equilibrium conditions, which would be the maximum expected long-term effect. 
Starting heads used for the simulations (fig. 20) were based on results of the final steady-state model calibration. In addition to the hypothetical pumping, average ground-water pumping-rates used for steady-state calibration (table 14) were used for these simulations.

Increased ground-water development in the Little Lehigh Creek basin was simulated as existing wells and hypothetical well fields pumping at the rate of: (1) one-half the 10-percent frequency of 1946-86 average annual base flow, which is equal to $22.8 \mathrm{ft}^{3} / \mathrm{s}$ (3.85 in/yr) or $14.81 \mathrm{Mgal} / \mathrm{d}$ (rounded to $15 \mathrm{Mgal} / \mathrm{d}$ ); (2) 10-percent frequency of 1946-86 average annual base flow, which is equal to $45.6 \mathrm{ft}^{3} / \mathrm{s}(7.69 \mathrm{in} / \mathrm{yr}$ ) or $29.58 \mathrm{Mga} 1 / \mathrm{d}$ (rounded to $30 \mathrm{Mgal} / \mathrm{d}$ ); and (3) 50-percent frequency of 1946-86 average annual base flow, which is equal to $76.6 \mathrm{ft}^{3} / \mathrm{s}(12.97 \mathrm{in} / \mathrm{yr}$ ) or $49.88 \mathrm{Mgal} / \mathrm{d}$ (rounded to $50 \mathrm{Mgal} / \mathrm{d}$ ). The $1975-83$ average pumping rate is $5.01 \mathrm{Mgal} / \mathrm{d}$ (rounded to $5 \mathrm{Mgal} / \mathrm{d})$. The frequency distribution of annual average base flow for Little Lehigh Creek near Allentown (gaging station 01451500) for 1946-86 is shown on figure 25, which graphically displays the data in table 4. The 10-percent frequency of 1946-86 average annual base flow is assumed to represent the dryyear base flow. The 50-percent frequency base flow is equal to the median of the 1946-86 annual base flows.

The 1975-83 average base flow simulated by the model is $8.7 .7 \mathrm{ft}^{3} / \mathrm{s}$ (14.80 in.). A ground-water pumping rate of 15,30 , and $50 \mathrm{Mgal} / \mathrm{d}$ is equal to 26,53 , and 88 percent of the 1975-83 average base flow, respectively.

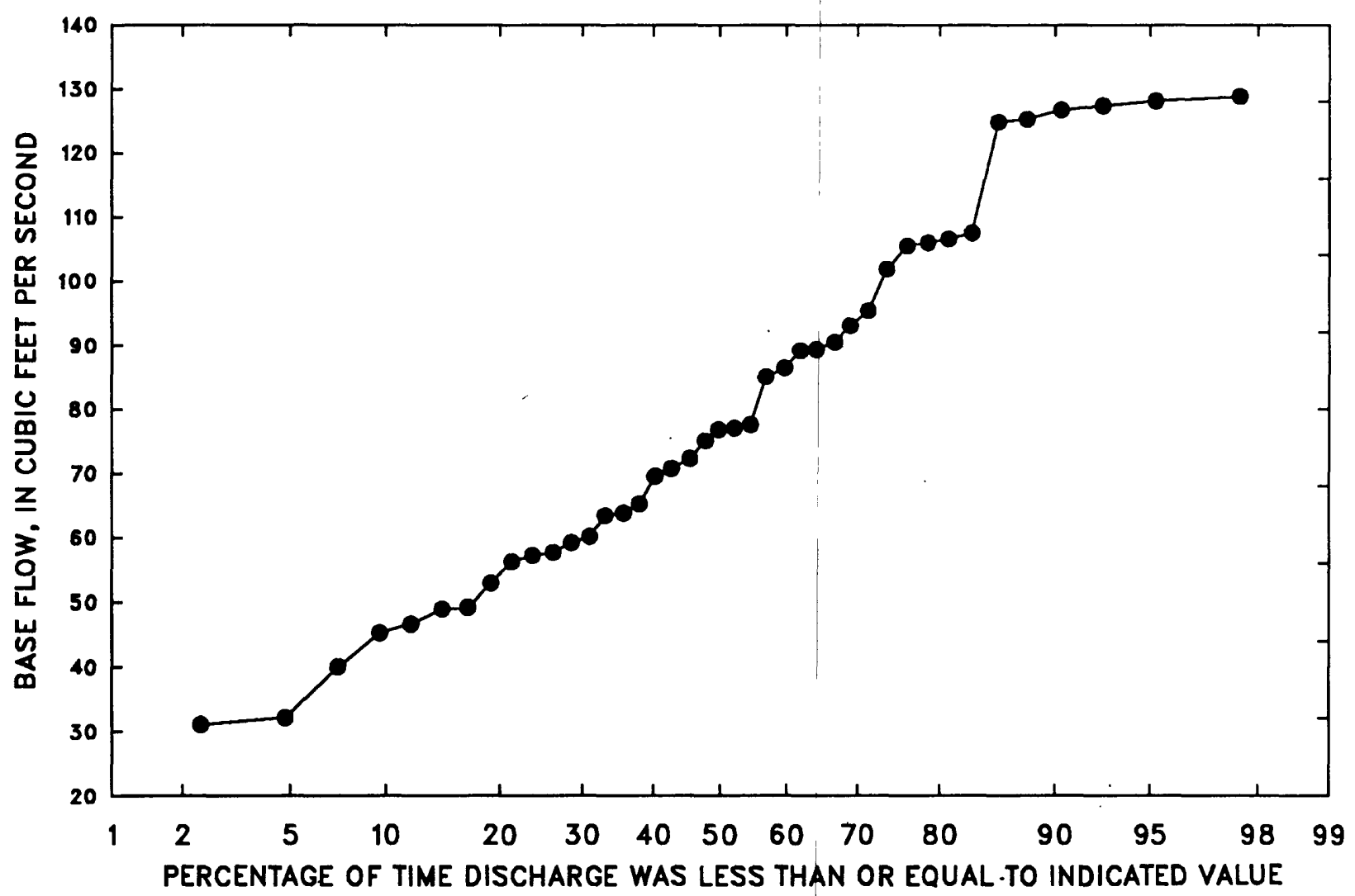

Figure 25.--Frequency distribution of base flow of Little Lehigh Creek near Allentown, 1946-86. 
Four hypothetical well fields were located near and away from Little Lehigh Creek in upstream and downstream areas (fig. 26) to estimate the effects of the location of pumped wells relative to the creek. Pumpage from the well fields is equal to the pumpage given above minus the 1975-83 average pumpage ( $5.04 \mathrm{Mgal} / \mathrm{d}$ ). Pumpage to simulate increased ground-water development was divided equally among 10 nodes. Therefore, each node in the well field is pumped at $1 \mathrm{Mgal} / \mathrm{d}$ for the one-half 10 -percent base-flow simulation (total of $10 \mathrm{Mgal} / \mathrm{d}$ ), $2.5 \mathrm{Mgal} / \mathrm{d}$ for the 10 -percent base-flow simulation (total of $25 \mathrm{Mgal} / \mathrm{d}$ ), and $4.5 \mathrm{Mgal} / \mathrm{d}$ for the 50 -percent base-flow simulation (total of $45 \mathrm{Mgal} / \mathrm{d}$ ).

The major sources of additional water pumped from wells are diverted base flow, induced infiltration of streamflow, induced underflow from the Sacony Creek basin, and reduction of underflow to the Cedar Creek basin. other sources of water include reduction in ground-water storage and evapotranspiration and water induced from outside the modeled carbonate rocks by lowered head gradients. Because a steady-state model is used, the mode1 cannot calculate the change in ground-water storage caused by increased pumping. Reduction in base flow in the model simulations represents diversion of ground water to pumping wells that would have otherwise been discharged to Little Lehigh Creek as base flow.

Well field 1 is located near the headwaters of Little Lehigh Creek and away from the stream (fig. 26). Pumping well field 1 at a rate of $10 \mathrm{Mgal} / \mathrm{d}$ would decrease base flow by $7.4 \mathrm{ft}^{3} / \mathrm{s}$ ( 8.4 percent) and induce an additional $2.54 \mathrm{Mgal} / \mathrm{d}$ of underflow from the adjacent Sacony Creek basin (table 16). Underflow to the Cedar Creek basin would be reduced by $0.3 \mathrm{Mgal} / \mathrm{d}$. Pumping well field 1 at a rate of $25 \mathrm{Mgal} / \mathrm{d}$ would decrease base flow by $19.2 \mathrm{ft} 3 / \mathrm{s}$ (21.9 percent) and induce an additional $7.28 \mathrm{Mgal} / \mathrm{d}$ of underflow from the Sacony Creek basin. Underflow to the Cedar Creek basin would be reduced by $0.69 \mathrm{Mgal} / \mathrm{d}$. Pumping well field 1 at a rate of $45 \mathrm{Mgal} / \mathrm{d}$ would decrease base flow by $33.8 \mathrm{ft}^{3} / \mathrm{s}$ ( 38.5 percent) and induce an additional $13.55 \mathrm{Mgal} / \mathrm{d}$ of underflow from the Sacony Creek basin. Underflow to the Cedar Creek basin would be reduced by $1.84 \mathrm{Mgal} / \mathrm{d}$. Pumping at well field 1 would have greatest effect on inducing underflow from the Sacony Creek basin and the least effect on reducing base flow and underflow to the Cedar Creek basin.

Well field 2 is located near the headwaters of Little Lehigh Creek near the stream (fig. 26). Pumping well field 2 at a rate of $10 \mathrm{Mgal} / \mathrm{d}$ would decrease base flow by $10.5 \mathrm{ft}^{3} / \mathrm{s}$ (12 percent) and induce an additional $0.97 \mathrm{Mgal} / \mathrm{d}$ of underflow from the Sacony Creek basin (table 16). Underflow to the Cedar Creek basin would be reduced by $0.23 \mathrm{Mgal} / \mathrm{d}$. Pumping well field 2 at a rate of $25 \mathrm{Mgal} / \mathrm{d}$ would decrease base flow by $23.6 \mathrm{ft}^{3} / \mathrm{s}$ (26.9 percent) and induce an additional $3.12 \mathrm{Mgal} / \mathrm{d}$ of underflow from the Sacony Creek basin. Underflow to the Cedar Creek basin would be reduced by $0.61 \mathrm{Mgal} / \mathrm{d}$. Pumping well field 2 at a rate of $45 \mathrm{Mgal} / \mathrm{d}$ would decrease base flow by $39.5 \mathrm{ft} 3 / \mathrm{s}$ ( 45 percent) and induce an additional $7.82 \mathrm{Mgal} / \mathrm{d}$ of underflow from the Sacony Creek basin. Underflow to the Cedar Creek basin would be reduced by $2.3 \mathrm{Mgal} / \mathrm{d}$. Pumping at well field 2 would have less effect on inducing underflow from the Sacony Creek basin and a greater effect on reducing base flow than would pumping at well field 1 because well field 2 is located closer to the Little Lehigh Creek than is well field 1, and more of the pumpage would come from diverted base flow. 


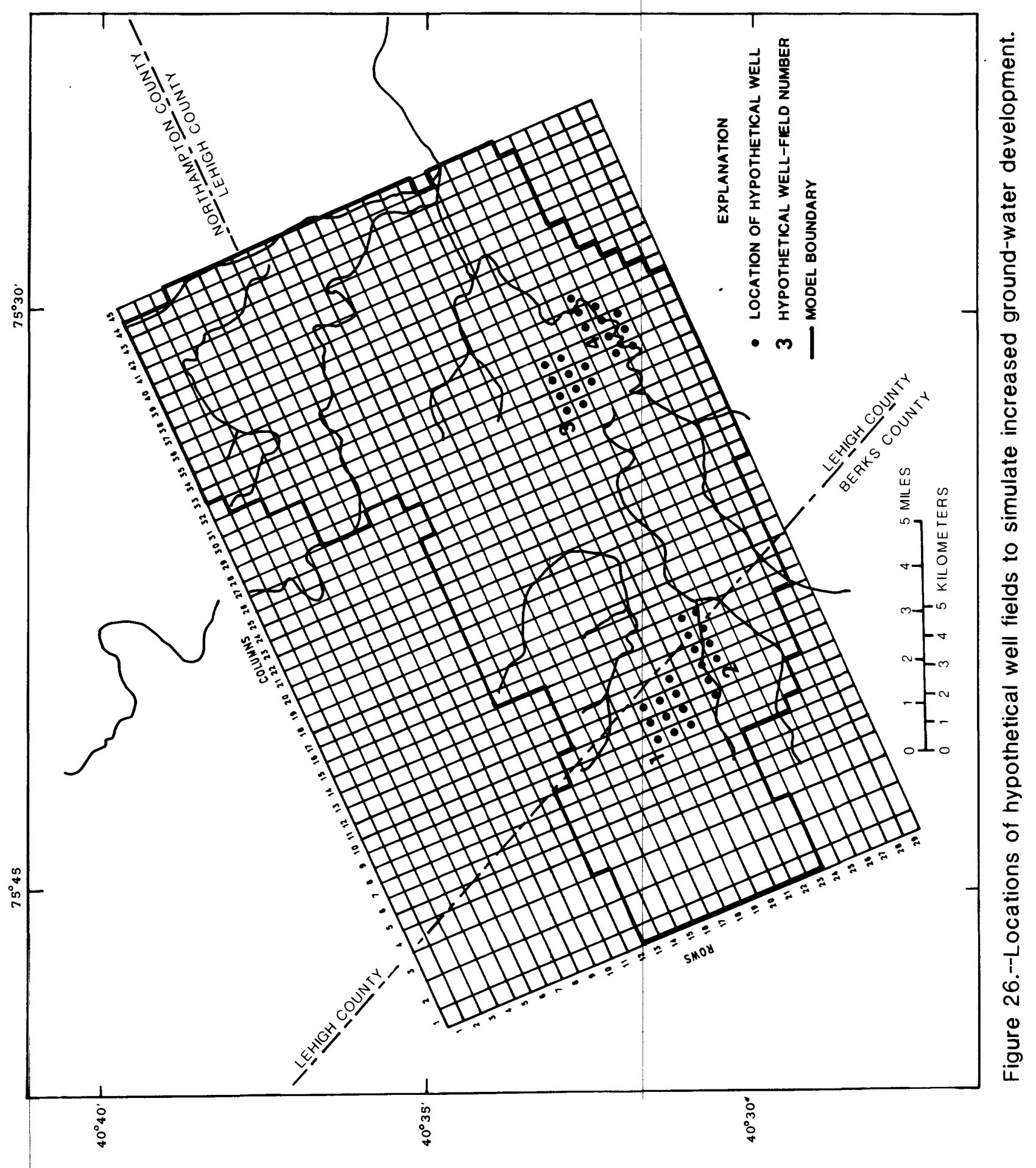




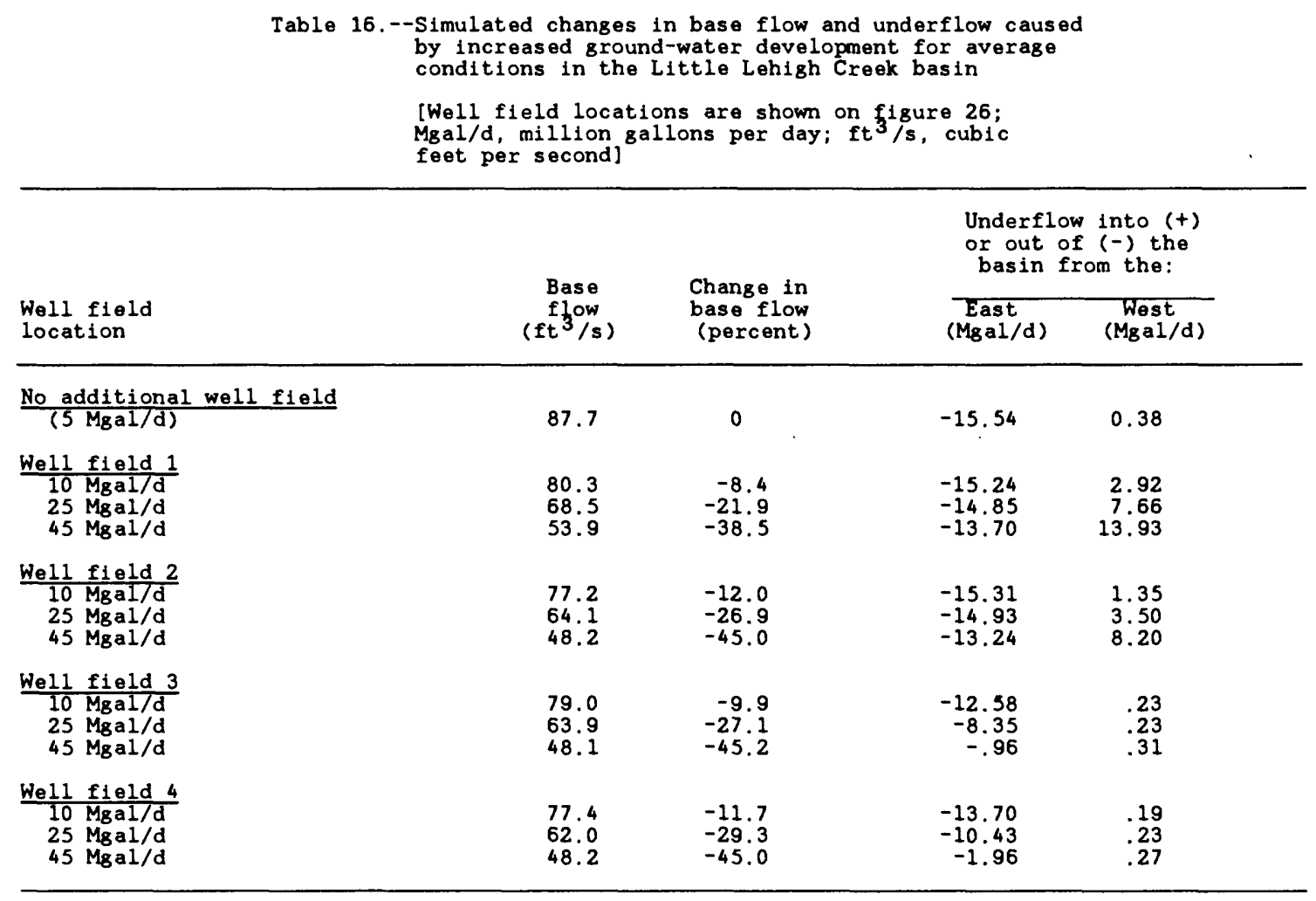

Well field 3 is located in the downstream area of the Little Lehigh Creek basin away from the stream (fig. 26). Pumping well field 3 at a rate of $10 \mathrm{Mgal} / \mathrm{d}$ would decrease base flow by $8.70 \mathrm{ft}^{3} / \mathrm{s}$ ( 9.9 percent) and reduce underflow to the Cedar Creek basin by $2.96 \mathrm{Mgal} / \mathrm{d}$ (table 16). Pumping well field 3 at a rate of $25 \mathrm{Mgal} / \mathrm{d}$ would decrease base flow by $23.8 \mathrm{ft}^{3} / \mathrm{s}$ (27.1 percent) and reduce underflow to the Cedar Creek basin by $7.19 \mathrm{Mgal} / \mathrm{d}$. Pumping well field 3 at a rate of $45 \mathrm{Mgal} / \mathrm{d}$ would decrease base flow by $39.6 \mathrm{ft}^{3} / \mathrm{s}$ ( 45.2 percent) and reduce underflow to the Cedar Creek basin by $14.58 \mathrm{Mgal} / \mathrm{d}$; this would stop nearly all underflow to the Cedar Creek basin under average conditions. Pumping at well field 3 would slightly reduce the underflow from the Sacony Creek basin. Pumping at well field 3 would have the greatest effect on reducing underflow to the Cedar Creek basin because the well field is located closest to the surface-water divide between Little Lehigh and Cedar Creeks.

Well field 4 is located in the downstream area of the Little Lehigh Creek basin near the stream (fig. 26). Pumping well field 4 at a rate of $10 \mathrm{Mgal} / \mathrm{d}$ would decrease base flow by $10.3 \mathrm{ft}^{3} / \mathrm{s}$ ( 11.7 percent) and reduce underflow to the Cedar Creek basin by $1.84 \mathrm{Mgal} / \mathrm{d}$ (table 16). Pumping well field 4 at a rate of $25 \mathrm{Mgal} / \mathrm{d}$ would decrease base flow by $25.7 \mathrm{ft}^{3} / \mathrm{s}$ ( 29.3 percent) and reduce underflow to the Cedar Creek basin by $5.11 \mathrm{Mgal} / \mathrm{d}$. Pumping well field 4 at a rate of $45 \mathrm{Mgal} / \mathrm{d}$ would decrease base flow by $39.5 \mathrm{ft}^{3} / \mathrm{s}$ ( 45 percent) and reduce underflow to the Cedar Creek basin by $13.58 \mathrm{Mgal} / \mathrm{d}$. Pumping at well field 4 would slightly reduce the underflow from the Sacony Creek basin. Pumping at well field 4 would have the greatest effect on reducing base flow because the well field is located close to the stream and distant from other sources of water to the pumped wells. 
The effects of increased ground-water development on base flow and underflow out of the Little Lehigh Creek basin were simulated for drought conditions. Increased ground-water development was simulated by locating hypothetical well fields in different parts of the basin (fig. 26). The same wells pumped at the same locations and rates that were used for simulations under average conditions also were used for simulations under drought conditions. Steady-state simulations were used to represent equilibrium conditions, which would be the maximum expected effect.

To simulate drought conditions, recharge was reduced from 21.75 in/yr to $12 \mathrm{in} / \mathrm{yr}$. This reduced the base flow of Little Lehigh Creek above streamflowgaging station 01451500 to $45.5 \mathrm{ft}^{3} / \mathrm{s}$ (7.68 in.), which is comparable to the 1981 water budget (table 12). Base flow includes $36.4 \mathrm{ft} / \mathrm{s}$ ( $6.14 \mathrm{in}$.) from the carbonate rocks and $9.1 \mathrm{ft}^{3} / \mathrm{s}$ (1.54 in.) from the noncarbonate rocks. A ground-water pumping rate of 15,30 , and $50 \mathrm{Mgal} / \mathrm{d}$ is equal to 51,102 , and 169 percent of the simulated drought base flow, respectively. Starting heads used for drought-condition simulations are heads simulated when the hydrologic system is in equilibrium with a recharge rate of $12 \mathrm{in} / \mathrm{yr}$.

Pumping well field 1, located near the headwaters of Little Lehigh Creek and away from the stream (fig. 26), under drought conditions at a rate of $10 \mathrm{Mgal} / \mathrm{d}$ would decrease base flow by $7.10 \mathrm{ft}^{3} / \mathrm{s}$ ( 15.6 percent) and induce an additional $3.54 \mathrm{Mgal} / \mathrm{d}$ of underflow from the adjacent Sacony Creek basin (table 17). Underflow to the Cedar Creek basin would be reduced by $0.38 \mathrm{Mgal} / \mathrm{d}$. Pumping well field 1 at a rate of $25 \mathrm{Mgal} / \mathrm{d}$ would decrease base flow by $16.7 \mathrm{ft}^{3} / \mathrm{s}$ ( 36.7 percent) and induce an additional $7.62 \mathrm{Mgal} / \mathrm{d}$ of underflow from the Sacony Creek basin. Underflow to the Cedar Creek basin would be reduced by $1.62 \mathrm{Mgal} / \mathrm{d}$. Pumping well field 1 at a rate of $45 \mathrm{Mgal} / \mathrm{d}$ would decrease base flow by $24.4 \mathrm{ft}^{3} / \mathrm{s}$ ( 53.6 percent) and induce an additional $8.69 \mathrm{Mgal} / \mathrm{d}$ of underflow from the Sacony Creek basin. Underflow to the Cedar Creek basin would be reduced by $8.0 \mathrm{Mgal} / \mathrm{d}$. Pumping at well field 1 would have the greatest effect of any of the pumping sicenarios on inducing underflow from the Sacony Creek basin and the least effect on reducing base flow and underflow to the Cedar Creek basin.

Pumping well field 2, located near the headwaters of Little Lehigh Creek near the stream (fig. 26), under drought conditions at the rate of $10 \mathrm{Mgal} / \mathrm{d}$ would decrease base flow by $8.6 \mathrm{ft} / 3 / \mathrm{s}$ (18.9 percent) and induce an additional $1.38 \mathrm{Mga} 1 / \mathrm{d}$ of underflow from the Sacony Creek basin (table 17). Underflow to the Cedar Creek basin would be reduced by $0.27 \mathrm{Mgal} / \mathrm{d}$. Pumping well field 2 at the rate of $25 \mathrm{Mgal} / \mathrm{d}$ would decrease base flow by $27.2 \mathrm{ft} 3 / \mathrm{s}$ ( 40.2 percent) and induce an additional $4.69 \mathrm{Mgal} / \mathrm{d}$ of underflow from the Sacony Creek basin. Underflow to the Cedar Creek basin would be reduced by $3.08 \mathrm{Mgal} / \mathrm{d}$. Pumping well field 2 at the rate of $45 \mathrm{Mgal} / \mathrm{d}$ would decrease base flow by $25.3 \mathrm{ft} / \mathrm{s}$ ( 55.6 percent) and induce an additional $7.69 \mathrm{Mgal} / \mathrm{d}$ of underflow from the Sacony Creek basin. Underflow to the Cedar Creek basin would be reduced by $8.85 \mathrm{Mgal} / \mathrm{d}$. Pumping at well field 2 would have less effect on inducing underflow from the Sacony Creek basin and a greater effect on reducing base flow than would pumping at well field 1 because well field 2 is located closer to Little Lehigh Creek than well field 1, and more of the pumpage would come from diverted base flow. 
Pumping well field 3, located in the downstream area of the Little Lehigh Creek basin away from the stream (fig. 26), under drought conditions at a rate of $10 \mathrm{Mgal} / \mathrm{d}$ would decrease base flow by $9.6 \mathrm{ft}^{3} / \mathrm{s}$ ( 21.1 percent) and reduce underflow to the Cedar Creek basin by $2.85 \mathrm{Mgal} / \mathrm{d}$ (table 17). Pumping well field 3 at the rate of $25 \mathrm{Mgal} / \mathrm{d}$ would decrease base flow by $21.9 \mathrm{ft} 3 / \mathrm{s}$ ( 48.1 percent) and reduce underflow to the Cedar Creek basin by $8.19 \mathrm{Mgal} / \mathrm{d}$. Pumping well field 3 at a rate of $45 \mathrm{Mgal} / \mathrm{d}$ would decrease base flow by $32.3 \mathrm{ft}^{3} / \mathrm{s}$ ( 80 percent). Underflow would change from an underflow of $15.12 \mathrm{Mgal} / \mathrm{d}$ from the Little Lehigh Creek basin to the Cedar Creek basin to ar. underflow of $2.25 \mathrm{Mgal} / \mathrm{d}$ from the Cedar Creek basin to the Little Lehigh Creek basin. Pumping at well field 3 would have the greatest effect of any of the pumping scenarios on the underflow to the Cedar Creek basin.

Table 17.--Simulated changes in base flow and underflow caused by increased ground-water development for drought conditions in the Little Lehigh Creek basin

[Well field locations are shown on figure 26; Mgal/d, million gallons per day; $\mathrm{ft}^{3} / \mathrm{s}$, cubic feet per second]

\begin{tabular}{|c|c|c|c|c|}
\hline \multirow[b]{2}{*}{$\begin{array}{l}\text { Well field } \\
\text { location }\end{array}$} & \multirow{2}{*}{$\begin{array}{l}\text { Base } \\
\mathrm{fl}^{\mathrm{w}} \\
\left(\mathrm{ft}^{3} / \mathrm{s}\right)\end{array}$} & \multirow{2}{*}{$\begin{array}{l}\text { Change in } \\
\text { base flow } \\
\text { (percent) }\end{array}$} & \multicolumn{2}{|c|}{$\begin{array}{l}\text { Underflow into }(+) \\
\text { or out of }(-) \text { the } \\
\text { basin from the: }\end{array}$} \\
\hline & & & $\begin{array}{l}\text { East } \\
(\mathrm{Mgal} / \mathrm{d})\end{array}$ & $\begin{array}{c}\text { West } \\
(\mathrm{Mgal} / \mathrm{d})\end{array}$ \\
\hline \multicolumn{5}{|c|}{ No additional well field } \\
\hline (5 Mgal/d) & 45.5 & 0 & -15.12 & 0.81 \\
\hline \multicolumn{5}{|l|}{ Well field 1} \\
\hline $10 \mathrm{Mgal} / \mathrm{d}$ & 38.4 & -15.6 & -14.74 & 4.35 \\
\hline $25 \mathrm{Mgal} / \mathrm{d}$ & 28.8 & -36.7 & -13.50 & 8.43 \\
\hline $45 \mathrm{Mgal} / \mathrm{d}$ & 21.1 & -53.6 & -7.12 & 9.50 \\
\hline \multicolumn{5}{|l|}{ Well field 2} \\
\hline $10 \mathrm{Mgal} / \mathrm{d}$ & 36.9 & -18.9 & -14.85 & 2.19 \\
\hline $25 \mathrm{Mgal} / \mathrm{d}$ & 27.2 & -40.2 & -12.04 & 5.77 \\
\hline $45 \mathrm{Mgal} / \mathrm{d}$ & 20.2 & -55.6 & -6.27 & 8.50 \\
\hline \multicolumn{5}{|l|}{ Well field 3} \\
\hline $10 \mathrm{Mgal} / \mathrm{d}$ & 35.9 & -21.1 & -12.27 & .58 \\
\hline $25 \mathrm{Mgal} / \mathrm{d}$ & 23.6 & -48.1 & -6.93 & .73 \\
\hline $45 \mathrm{Mgal} / \mathrm{d}$ & 13.2 & -80.0 & 2.25 & 1.12 \\
\hline \multicolumn{5}{|l|}{ Well field 4} \\
\hline $10 \mathrm{Mgal} / \mathrm{d}$ & 34.2 & -24.8 & -13.39 & .54 \\
\hline $25 \mathrm{Mgal} / \mathrm{d}$ & 23.2 & -49.0 & -8.53 & .69 \\
\hline $45 \mathrm{Mgal} / \mathrm{d}$ & 14.6 & -67.9 & 2.58 & .88 \\
\hline
\end{tabular}

Pumping well field 4, located in the downstream area of the Little Lehigh Creek basin near the stream (fig. 26), under drought conditions at a rate of $10 \mathrm{Mgal} / \mathrm{d}$ would decrease base flow by $11.3 \mathrm{ft}^{3} / \mathrm{s}$ ( 24.8 percent) and reduce underflow to the Cedar Creek basin by $1.73 \mathrm{Mgal} / \mathrm{d}$ (table 17). Pumping well field 4 at a rate of $25 \mathrm{Mgal} / \mathrm{d}$ would decrease base flow by $22.3 \mathrm{ft} / \mathrm{s}$ (49 percent) and reduce underflow to the Cedar Creek basin by $6.63 \mathrm{Mgal} / \mathrm{d}$. Pumping well field 4 at a rate of $45 \mathrm{Mgal} / \mathrm{d}$ would decrease base flow by $30.9 \mathrm{ft}^{3} / \mathrm{s}$ ( 67.9 percent). Underflow would change from an underflow of 15.12 Mgal/d from the Little Lehigh Creek basin to the Cedar Creek basin to an underflow of $2.58 \mathrm{Mgal} / \mathrm{d}$ from the Cedar Creek basin to the Little Lehigh Creek basin. Pumping at well field 4 would have the greatest effect on reducing base flow. 
The model simulations demonstrate the difficulty of ground-water-resource planning in carbonate-rock terranes. Ground-water-resource planning is often based on a surface-water-basin approach with ground-water withdrawals assumed to cause a one-to-one reduction in base flow. Model simulations show that ground-water withdrawals do not cause a proportional reduction in base flow. Under average conditions, ground-water withdrawals are equal to 48 to 70 percent of simulated base-flow reductions. Under drought conditions, ground-water withdrawals are equal to 35 to 73 percent of simulated base-flow reductions.

The effect of pumping largely depends on the location of the wells. In the Little Lehigh basin, surface-water and ground-water divides do not coincide, and ground-water development, especially near surface-water divides, can cause ground-water divides to shift and induce ground-water underflow from adjacent basins. Large-scale ground-water withdrawals would not necessarily produce reductions of base flow in the basin where pumping takes place because of shifts in the ground-water divide; however, such shifts may reduce base flow in adjacent surface-water basins. For example, the simulated pumping of well field 1 at a rate of $45 \mathrm{Mgal} / \mathrm{d}$ under average conditions--a rate equal to 79 percent of the base flow of Little Lehigh Creek--reduces the base flow of. Little Lehigh Creek by 38.5 percent; the reduction in base flow is equal to 49 percent of the pumpage. However, $13.55 \mathrm{Mgal} / \mathrm{d}$ (30.1 percent of the pumpage) of ground-water that would have been discharged as base flow to Sacony Creek is induced to flow into the Little/Lehigh Creek basin by pumping, and the base flow of Sacony Creek is reduced. 


\section{SUMMARY}

The Little Lehigh Creek basin is underlain mainly by a complex assemblage of highly-deformed Cambrian and Ordovician carbonate rocks. The Leithsville Formation, Allentown Dolomite, Beekmantown Group, and Jacksonburg Limestone act as a single hydrologic unit. Ground water is generally under water-table conditions in the carbonate rocks, but confined conditions exist locally. Ground water moves through fractures and other secondary openings in the carbonate-aquifer system. The yield of wells depends on the size and number of secondary openings intersected below the water table. The frequency of water-bearing zones decreases with depth. Fifty-one percent of water-bearing openings are encountered within $150 \mathrm{ft}$ of land surface, and 82 percent are encountered within $250 \mathrm{ft}$ of land surface.

Aquifer tests were conducted at two wells in the Epler Formation of the Beekmantown Group. Well LE-1319 was pumped for 70 hours at an average rate of $1,900 \mathrm{gal} / \mathrm{min}$. The transmissivity, calculated from results of the aquifer test, was $33,000 \mathrm{ft}^{2} / \mathrm{d}$. Well LE-1355 was pumped for 74 hours at a rate of $1,400 \mathrm{gal} / \mathrm{min}$. The transmissivity, calculated from results of the aquifer test, was $4,400 \mathrm{ft}^{2} / \mathrm{d}$.

Ground-water discharge (base flow) comprises 69 to 92 percent of the annual flow of Little Lehigh Creek measured at streamflow-gaging station 01451500 during 1946-86. Annual base flow ranged from 5.24 to 21.74 in/yr. The median ground-water discharge was $12.97 \mathrm{in} / \mathrm{yr}$, which was 82 percent of streamflow.

Ground-water and surface-water divides do not coincide in the Little Lehigh Creek basin. As a result, ground-water underflow to adjoining surfacewater basins occurs. The underflow out of the Little Lehigh Creek basin above gaging station 01451500 to the Cedar Creek basin in 1987 is estimated to be about 4 in.

In the western part of the basin, particularly the upper reaches of Iron Run, Schaefer Run, and Toad Creek, streams lose water to the ground-water system when the altitude of the water table at the stream is below the altitude of the stream surface. In the upper part of the Little Lehigh Creek basin, the water table is generally a few feet to tens of feet below stream beds. In the eastern part of the basin, ground water discharges to streams and comprises the base-flow component of streamflow. All streamflow lost in the upper part of the basin returns to Little Lehigh Creek as ground-water discharge to gaining reaches in the lower part of the basin.

Annual water budgets for 1975-83 and an average water budget for those years were prepared for the $80.8 \mathrm{mi}^{2}$ part of the basin above gaging station 01451500. For 1975-83, average annual streamflow was 19.09 in., evapotranspiration was $20.09 \mathrm{in.}$, diversions from the basin were $1.30 \mathrm{in.}$, ground-water storage declined $0.16 \mathrm{in.}$, and net underflow out of the basin was estimated to be 4.0 in. Average annual recharge for $1975-83$ was 21.75 in.

Cessation of pumping at the Lehigh Portland quarry at Fogelsville and the development of ground water for public supply in the Schantz Spring basin has not affected the flow of Schantz spring. A double-mass curve of the 
cumulative flow of Schantz Spring as a function of cumulative precipitation of Allentown for 1954-84 plots as a straight line, indicating that no change in the constant of proportionality between the flow of Schantz spring and precipitation occurred.

Ground-water flow in the Little Lehigh Creek basin was simulated by a finite-difference, two-dimensional computer model. The geologic units in the modeled area were simulated as a single water-table aquifer. Recharge to, ground-water flow through, and discharge from the carbonate rocks of the Little Lehigh Creek basin were simulated. Sources of water to the modeled carbonate rocks are areally-distributed recharge from precipitation and lateral ground-water flow from noncarbonate rocks to the north and south of the carbonate valley. Discharge of water from the modeled hydrologic system is by pumping from wells, ground-water discharge to streams, and ground-water evapotranspiration.

The area between the Lehigh River and Sacony Creek was modeled to include the natural hydrologic boundaries of the ground-water-flow system. The modeled area was discretized into a rectangular grid of 29 rows and 45 columns containing 861 active cells representing $134 \mathrm{mi}^{2}$. On the northwestern and southeastern sides of the modeled area, the geologic contact between the carbonate and noncarbonate rocks is a head-dependent boundary. On the northeastern side of the modeled area, the Lehigh River is simulated as a specified-head (constant-head) boundary. On the southwestern side, the boundary is Sacony Creek, which is represented by a head-dependent boundary. The model lower boundary is a specified-flux (no-flow) boundary $600 \mathrm{ft}$ below land surface. The model upper boundary is represented by the water-table surface, which is a specified-flux boundary.

The ground-water-flow model of the Little Lehigh Creek basin was calibrated under steady-state conditions using 1975-83 average recharge, evapotranspiration, and pumping rates. The recharge rate used for model simulations was $4.97 \times 10^{-3} \mathrm{ft} / \mathrm{d}(21.75 \mathrm{in} / \mathrm{yr})$ and the evapotranspiration rate was $4.59 \times 10^{-3} \mathrm{ft} / \mathrm{d}(20.09 \mathrm{in} / \mathrm{yr})$. Average 1975-83 pumpage from the Little Lehigh Creek basin above gaging station 01451500 is $5.04 \mathrm{Mgal} / \mathrm{d}$.

Each geologic unit was assigned a different hydraulic conductivity. Initial aquifer hydraulic conductivity was estimated from specific-capacity data. Schantz and Crystal Springs were simulated as drains; drain conductance and drain elevation were adjusted to simulate 1975-83 average spring discharges of $7.4 \mathrm{Mgal} / \mathrm{d}$ for Schantz Spring and $4.0 \mathrm{Mgal} / \mathrm{d}$ for Crystal Spring.

The average (1975-83) water budget for the Little Lehigh Creek basin was approximated by a steady-state simulation. The simulated base flow from the carbonate rocks of the Little Lehigh Creek basin above gaging station 01451500 is $11.85 \mathrm{in} / \mathrm{yr}$. The simulated ground-water underflow from the Little Lehigh Creek basin to the Cedar Creek basin is 4.00 in/yr. For steady-state calibration, the RMSE between observed and simulated heads was $21.19 \mathrm{ft}$ for 316 cells in the Little Lehigh Creek basin. 
The model was found to be very sensitive to the recharge rate and moderately sensitive to aquifer hydraulic conductivity, aquifer thickness, streambed hydraulic conductance, and head in the source supplying water to the head-dependent boundary. The model was insensitive to the ground-water evapotranspiration rate, evapotranspiration extinction depth, and headdependent boundary hydraulic conductance.

The effects of increased ground-water development on base flow and underflow out of the Little Lehigh Creek basin under average and drought conditions were simulated by locating a hypothetical well field in different parts of the basin. Steady-state simulations were used to represent equilibrium conditions, which would be the maximum expected long-term effect.

Increased ground-water development in the Little Lehigh Creek basin was simulated as existing wells and hypothetical well fields pumped at the rate of (1) one-half the 10-percent frequency of 1946-86 average annual base flow (15 Mgal/d), (2) 10-percent frequency of 1946-86 average annual base flow (30 Mgal/d), and (3) 50-percent frequency of 1946-86 average annual base flow (50 Mgal/d). The 1975-83 average pumping rate was $5 \mathrm{Mgal} / \mathrm{d}$. Four hypothetical well fields were located near and away from Little Lehigh Creek in upstream and downstream areas.

Pumping well field 1 , located near the headwaters of Little Lehigh Creek and away from the stream, at a rate of $45 \mathrm{Mgal} / \mathrm{d}$ under average conditions would decrease the base flow of Little Lehigh Creek by $33.8 \mathrm{ft}^{3} / \mathrm{s}$ ( 38.5 percent), induce an additional $13.55 \mathrm{Mgal} / \mathrm{d}$ of underflow from the Sacony Creek basin, and reduce underflow to the Cedar Creek basin by $1.84 \mathrm{Mgal} / \mathrm{d}$. Pumping well field 1 at a rate of $45 \mathrm{Mgal} / \mathrm{d}$ under drought conditions would decrease base flow by $24.4 \mathrm{ft}^{3} / \mathrm{s}$ (53.6 percent), induce an additional $8.69 \mathrm{Mgal} / \mathrm{d}$ of underflow from the Sacony Creek basin, and reduce underflow to the Cedar Creek basin by $8.0 \mathrm{Mgal} / \mathrm{d}$. Pumping at well field 1 would have the greatest effect of all the pumping scenarios on inducing underflow from the Sacony Creek basin and the least effect on reducing base flow and underflow to the Cedar Creek basin.

Pumping well field 2, located near the headwaters of Little Lehigh Creek near the stream, at a rate of $45 \mathrm{Mgal} / \mathrm{d}$ under average conditions would decrease the base flow of Little Lehigh Creek by $39.5 \mathrm{ft}^{3} / \mathrm{s}$ ( 45 percent), induce an additional $7.82 \mathrm{Mgal} / \mathrm{d}$ of underflow from the Sacony Creek basin, and reduce the underflow to the Cedar Creek basin by $2.3 \mathrm{Mgal} / \mathrm{d}$. Pumping well field 2 at a rate of $45 \mathrm{Mgal} / \mathrm{d}$ under drought conditions would decrease base flow by $25.3 \mathrm{ft}^{3} / \mathrm{s}$ ( 55.6 percent), induce an additional $7.69 \mathrm{Mgal} / \mathrm{d}$ of underflow from the Sacony Creek basin, and reduce the underflow to the Cedar Creek basin by $8.85 \mathrm{Mgal} / \mathrm{d}$. Pumping at well field 2 would have less effect on inducing underflow from the Sacony Creek basin and a greater effect on reducing base flow than would pumping at well field 1 because well field 2 is located closer to Little Lehigh Creek than well field 1 , and more of the pumpage would come from diverted base flow.

Pumping well field 3 , located in the downstream area of the Little Lehigh Creek basin away from the stream, at a rate of $45 \mathrm{Mgal} / \mathrm{d}$ under average conditions would decrease the base flow of Little Lehigh Creek by $39.6 \mathrm{ft}^{3} / \mathrm{s}$ 
( 45.2 percent) and reduce underflow to the Cedar Creek basin by $14.58 \mathrm{Mgal} / \mathrm{d}$; this would stop nearly all underflow to the Cedar Creek basin. Pumping well field 3 at a rate of $45 \mathrm{Mgal} / \mathrm{d}$ under drought conditions would decrease base flow by $32.3 \mathrm{ft}^{3} / \mathrm{s}$ ( 80 percent) and change the underflow of $15.12 \mathrm{Mgal} / \mathrm{d}$ from the Little Lehigh Creek basin to the Cedar Creek basin to an underflow of $2.25 \mathrm{Mgal} / \mathrm{d}$ from the Cedar Creek basin to the Little Lehigh Creek basin. Pumping at well field 3 would have the most effect of all the pumping scenarios on the underflow to the Cedar Creek basin.

Pumping well field 4, located in the downstream area of the Little Lehigh Creek basin near the stream, at a rate of $45 \mathrm{Mgal} / \mathrm{d}$ under average conditions would decrease base flow by $39.5 \mathrm{ft}^{3} / \mathrm{s}$ ( 45 percent) and reduce underflow to the Cedar Creek basin by $13.58 \mathrm{Mgal} / \mathrm{d}$. Pumping well field 4 at a rate of $45 \mathrm{Mgal} / \mathrm{d}$ under drought conditions would decrease base flow by $30.9 \mathrm{ft}^{3} / \mathrm{s}$ ( 67.9 percent) and change the underflow of $15.12 \mathrm{Mgal} / \mathrm{d}$ from the Little Lehigh Creek basin to the Cedar Creek basin to an underflow of $2.58 \mathrm{Mgal} / \mathrm{d}$ from the Cedar Creek basin to the Little Lehigh Creek basin. Pumping at well field 4 would have the greatest effect of all the pumping scenarios on reducing base flow.

Model simulations show that ground-water withdrawals do not cause a proportional reduction in base flow. Under average conditions, ground-water withdrawals are equal to 48 to 70 percent of simulated base-flow reductions. Under drought conditions, ground-water withdrawals are equal to 35 to 73 percent of simulated base-flow reductions..

The effect of pumping largely depends on well location. In the Little Lehigh Creek basin, surface-water and ground-water divides do not coincide, and ground-water development, especially near surface-water divides, can cause ground-water divides to shift and induce ground-water underflow from adjacent basins. Large-scale ground-water pumping would not necessarily produce reductions in base flow in the basin where pumping occurs because of shifts in the ground-water divide; however, such shifts could reduce base flow in adjacent surface-water basins. 


\section{REFERENCES CITED}

Berg, T.M., and Dodge, C.M., 1981, Atlas of preliminary geologic quadrangle maps of Pennsylvania: Pennsylvania Geological Survey, 4th ser., Map 61, scale $1: 62,500,636 \mathrm{p}$.

Berg, T.M., McInerney, M.K., Way, J.H., and MacLachlan, D.B., 1986, Stratigraphic correlation chart of Pennsylvania: Pennsylvania Geological Survey, 4th ser., General Geology Report 75, 1 p1.

Braun, D.D., 1988, Glacial geology of the anthracite and North Branch Susquehanna lowland regions in Inners, J.D., ed., Bedrock and glacial geology of the North Branch Susquehanna lowland and the eastern Middle Anthracite field, northeastern Pennsylvania: Guide book for 53rd annual Field Conference of Pennsylvania Geologists, Harrisburg, Field Conference of Pennsylvania Geologists, Inc.

Drake, A.A., Jr., 1960, Taconic and post taconic folds in eastern Pennsylvania and western New Jersey: U.S. Geological Survey Professional Paper 400-B, p. $180-181$.

-.-1965, Carbonate rocks of Cambrian and Ordovician age, Northampton and Bucks Counties, eastern Pennsylvania and Warren and Hunterdon Counties, western New Jersey: U.S. Geological Survey Bulletin 1194-L, 7 p.

-1978, The Lyon Station - Paulins Kill Nappe-the frontal structure of the Musconetcong nappe system in eastern Pennsylvania and New Jersey: U.S. Geological Survey Professional Paper 1023, 20 p.

-1987, Geologic map of the Topton Quadrangle, Lehigh and Berks Counties, Pennsylvania: U.S. Geological Survey Map GQ-1607, 1 sheet, scale $1: 24,000$.

Epstein, J.B., Sevon, W.D., and Glaeser, J.D., 1974, Geology and mineral resources of the Lehighton and Palmerton quadrangles, Carbon and Northampton Counties, Pennsylvania: Pennsylvania Geological Survey, 4 th ser., Atlas 195cd, $460 \mathrm{p}$.

Hobson, J.P., 1963, Stratigraphy of the Beekmantown Group in southeastern Pennsylvania: Pennsylvania Geological Survey, 4th ser., General Geology Report 37, $331 \mathrm{p}$.

Kochanov, W.E., 1987, Sinkholes and karst-related features of Lehigh County, Pennsylvania: Pennsylvania Geological Survey, 4th ser., Open-File Report 8701,8 p., 6 sheets, scale 1:24,000.

Lash, G.G., 1985, Geologic map of the Kutztown Quadrangle, Berks and Lehigh Counties, Pennsylvania: U.S. Geological Survey Map GQ-1557, 1 sheet, scale $1: 24,000$. 
Lash, G.G., and Drake, A.A., Jr., 1984, The Richmond and Greenwich slices of the Hamburg Klippe in eastern Pennsylvania--stratigraphy, sedimentology, structure, and plate tectonic implications: U.S. Geological Survey Professional Paper 1312, 40 p.

Leverett, Frank, 1934, Glacial deposits outside the Wisconsin terminal moraine in Pennsylvania: Pennsylvania Geological Survey, 4 th ser., General Geology Report 7, 123 p.

Lohman, S.W., 1979, Ground-water hydraulics: U.S. Geological Survey Professional Paper 708, 70 p.

Lyttle, P.T., and Epstein, J.B., 1987, Newark $1^{\circ} \times 2^{\circ}$ quadrangle, New Jersey, Pennsylvania, and New York: U.S. Geological Survey Miscellaneous Investigations Series I-1715, 2 sheets, scale 1:250,000.

McDonald, M.G., and Harbaugh, A.W., 1988, A modular three-dimensional finitedifference ground-water flow model: U.S. Geological Survey Techniques of Water Resources Investigations, Book 6, Chapter Al.

Maclachlan, D.B., 1967, Structure and stratigraphy of the limestones and dolomites of Dauphin County, Pennsylvania: Pennsylvania Geological Survey, 4th ser., Bulletin 644, $168 \mathrm{p}$.

-..-1979, Geology and mineral resources of the Temple and Fleetwood quadrangles, Berks County, Pennsylvania: Pennsylvania Geological Survey, 4th ser., Atlas 187ab, $71 \mathrm{p}$.

-..-1983, Geology and mineral resources of the Reading and Birdsboro quadrangles, Berks County, Pennsylvania: Pennsylvania Geological Survey, 4 th ser., Atlas $187 \mathrm{~cd}, 1$ sheet, scale $1: 24,000$.

MacLachlan, D.B., Buckwalter, T.V., and McLaughlin, D.B., 1975, Geology and mineral resources of the Sinking Spring 7.5-minute quadrangle, Pennsylvania: Pennsylvania Geological Survey, 4th ser., Atlas 117d, $228 \mathrm{p}$.

Meisler, Harold, 1963, Hydrogeology of the carbonate rocks of the Lebanon Valley, Pennsylvania: Pennsylvania Geological Survey, 4th ser., Water Resource Report 18, 81 p.

Meisler, Harold, and Becher, A.E., 1971, Hydrogeology of the carbonate rocks of the Lancaster 15-minute quadrangle, southeastern Pennsylvania: Pennsylvania Geological Survey, 4th ser., Water Resource Report 26, $149 \mathrm{p}$.

Miller, B.L., 1941, Lehigh County, Pennsylvania - geology and geography: Pennsylvania Geological Survey, 4th ser., Bulletin C39, 432 p. 


\section{REFERENCES CITED--Continued}

Myers, P.B., Jr., and Perlow, Michael, Jr., 1984, Development, occurrence, and triggering mechanisms of sinkholes in the carbonate rocks of the Lehigh Valley, eastern Pennsylvania, in Proceedings of the First Multidisciplinary Conference on Sinkholes: Orlando, Florida, October 15-17, 1984 , p. 111-115.

National Oceanic and Atmospheric Administration, 1982, Monthly normals of temperature, precipitation, and heating and cooling degrees days 1951-80: Climatography of the United States, Number 81.

Poth, C.W., 1972, Hydrology of the Martinsburg Formation in Lehigh and Northampton Counties, Pennsylvania: Pennsylvania Geological Survey, 4 th ser., Water Resource Report 30, 52 p.

Searcy, J.K., and Hardison, C.H., 1960, Double-mass curves: U.S. Geological Survey Water-Supply Paper 1541-B, p. 31-66.

Sevon, W.D., Crow1, G.H., and Berg, T.M., 1975, The late Wisconsin drift border in northeastern Pennsylvania: 40th Annual Field Conference of Pennsylvania Geologists Guidebook, 108 p.

Sloto, R.A., 1991, A computer method for estimating ground-water contribution to streamflow using hydrograph-separation techniques in Proceedings of the U.S. Geological Survey Nation Computer Technology Meeting: U.S. Geological Survey Water-Resources Investigations Report 90-4162, p. 101110 .

Theis, C.V., 1963, Estimating the transmissibility of a water-table aquifer from the specific capacity of a well: U.S. Geological Survey Water Supply Paper 1536-I, p. 332-341.

Wood, C.R., Flippo, H.N., Lescinsky, J.B., and Barker, J.L., 1972, Water resources of Lehigh County, Pennsylvania: Pennsylvania Geological Survey, 4th ser., Water Resource Report 31, $263 \mathrm{p}$.

Wood, C.R., and MacLachlan, D.B., 1978, Geology and ground-water resources of northern Berks County, Pennsylvania: Pennsylvania Geological Survey, 4th ser., Water Resource Report 44, 91 p. 
Table 18.--Records of selected wells and springs

Local number: BE, well in Berks County; LE, well in Lehigh County; LE-Sp, spring in Lehigh County.

Site-ID: Well location. First six numbers are latitude in degrees, minutes, and seconds. Next seven numbers are longitude in degrees, minutes, and seconds. Last two numbers are sequence number.

Use of site: 0 , observation well; U, unused; $W$, withdrawal; $\mathrm{Z}$, destroyed.

Use of water: A, air conditioning; C, commercial; $\mathrm{H}$, domestic; I, irrigation; $\mathrm{N}$, industrial; $\mathrm{P}$, public supply; $\mathrm{R}$, recreational; $\mathrm{T}$, institutional; $\mathrm{U}$, unused; $Z$, other.

Aquifer codes: 364JKBG, Jacksonburg Limestone, undivided; 364JKBGC, Jacksonburg Limestone, cement limestone facies; 364JKBGR, Jacksonburg Limestone, cement rock facies; 364BKMN, Beekmantown Group; 3640NLN, Onteluantee Formation; 367EPLR, Epler Formation; 371ALNN, Allentown Dolomite, undivided; 371TCKR, Allentown Dolomite, Tuckerton Member; 374LSVL, Leithsville Formation; 377HRDS, Hardyston Quartzite.

Altitude of land surface is estimated from topographic maps. Datum is National Geodetic Vertical Datum of 1929.

Water level is in feet below land surface. A, airline; M, measured; $R$, reported. 


\begin{tabular}{|c|c|c|c|c|c|c|}
\hline $\begin{array}{l}\text { Local } \\
\text { number }\end{array}$ & $\begin{array}{c}\text { Site } \\
\text { identification } \\
\text { number }\end{array}$ & Owner & Driller & $\begin{array}{l}\text { Date } \\
\text { drilled }\end{array}$ & $\begin{array}{l}\text { Use } \\
\text { of } \\
\text { site }\end{array}$ & $\begin{array}{l}\text { Use } \\
\text { of } \\
\text { water }\end{array}$ \\
\hline
\end{tabular}

$\begin{array}{rr}\text { BE- } 617 & 403000075421401 \\ 619 & 402954075420701 \\ 623 & 402615075530501 \\ 1049 & 403025075145901 \\ 1050 & 403025075415902 \\ & \\ 1051 & 403029075415901 \\ 1411 & 403152075401001 \\ 1423 & 403026075395501 \\ 1424 & 403034075400001 \\ 1445 & 403055075455802 \\ 1447 & 403119075460801\end{array}$
72403645075311901 $84 \quad 403222075290301$

$85 \quad 403224075290201$

86403141075301001

87403300075285901

193403052075333601

207403523075330401

$226 \quad 403653075285201$

263403754075322301

265403757075321801

$268 \quad 403755075322101$

410

463

479.

500

502

504

505

506

521

524

525

528

529

530

531

532

533
544

588

593

597

644
677

678

705

710

714

801

804

810

866
403051075333701

403255075303901

403130075330502 403221075300301 403902075301501 403409075323601

403345075314001 403323075340501 403226075354901 403120075303201

403512075324001 403519075323101 403433075311901 403416075315701 403447075310101

403441075311201 403437075310601 403645075313201 403602075352601 403105075330201

403130075330501 403818075300301 403817075261502 403429075392401 403256075303802

403328075361301 403523075330301 403413075330501 403341075343101

403342075343101 403415075330901 403433075324601 403226075343001 403438075393801 403416075320401
403415075320301 403405075321401 403755075340601 403323075334801
Topton Borough Topton Borough

Maidencreek Township

Caloric Corp.

Caloric Corp.

Caloric Corp.

Boyd, Randali

Atlas Minerals \& Chemicals, Inc.

Atlas Minerals \& Chemicals, Inc.

Kutztown Borough

Kutztown Borough

BERKS COUNTY

Grandview Water Co.

Grandview Water Co.

Emmaus Borough

Emmaus Borough

Emmaus Borough

Emmaus Borough

Allen Organ Co.

S. Whitehall Twp.

$\overline{--}$

Harry H. Herman

Harry $\mathrm{H}$. Herman

Harry H. Herman

R.H. Odenheiner Co.

R.H. Odenheiner Co.

$R . H$. Odenheiner $C O$.

Harrisburg's Kohl Bros.

C.S. Garber \& Sons, Inc.

$\begin{array}{ccc}1935 & \text { U } & \text { U } \\ 1921 & \text { W } & \text { P } \\ -- & \text { U } & \text { N } \\ -- & \text { W } & \text { N } \\ -- & \text { W } & \text { N } \\ 1979 & \text { W } & \text { U } \\ 1964 & \text { W } & \text { H } \\ 1975 & \text { W } & \text { N } \\ 1982 & \text { W } & \text { P } \\ 1983 & \text { W } & \text { P }\end{array}$

LEHIGH COUNTY

S.M.S. Textile Mills

IMC Pitman-Moore, Inc.

IMC Pitman-Moore, Inc.

IMC Pitman-Moore, Inc.

Lehigh Country Club

Brookside Country Club

Emmaus Borough

Whitehall Iwp. Authority

Whitehall Two. Authority

Country Club Gardens Water Co.

Country Home Acres Water Co.

Lehigh County Authority

Lehigh County Authority

Lehigh County Authority

Emmaus Borough

S. Whitehall Twp. Authority S. Whitehall Twp. Authority

5. Whitehall Twp. Authority

5. Whitehall Twp. Authority

Country Club Gardens Water Co.

Country Club Gardens Water Co.

Country Club Gardens Water Co.

Grandview Water Co.

Green Hills Water Co.

Macungie Borough

Brookside Country Club

Whitehall Twp. Authority

Witko Trailer Court

Haaf, Charles

Lehigh Country Club

Packaging Corp. of America

5 . Whitehall Authority

Lehigh County Authority

Eastern Industries, Inc.

Red Maple Acres Trailer Court

Red Maple Acres Trailer Court Eastern Industries, Inc.

Cedarbrook

Knepper, Paul

Lichtenwalner, A.

Allen Organ Co.

Clearview Manor Water Co.

Clearview Manor Water Co.

Clearview Manor Water Co.

S. Whitehall Twp. Authority
Harry H. Herman

Harry $H$. Herman

M.B. Biery

1948

1951

M.B. Biery

Artesian Well Drls. Co.

C.S. Garber \& Sons, Inc.

M.B. Biery

M.B. Biery

M.B. Biery

M.B. Biery

M.B. Biery

M.B. Biery

C.S. Garber \& Sons, Inc.

$$
\text { -- }
$$$$
--
$$

C.S. Garber \& Sons, Inc.

C.S. Garber \& Sons, Inc.

C.S. Garber \& Sons, Inc.

R.H. Odenheiner Co.

Harry $\mathrm{H}$. Herman

R.H. Odenheiner Co.

R.H. Odenheiner Co.

$R$. H Odenheiner Co.

Richard E. Henry

R.H. Odenheiner Co.

Lehigh Valley Well \& Pump Co.

R.H. Odenheiner Co. 1953

R. H. Ode

Kermit $\mathbf{S}$. Snyder

R.H. Odenheiner Co.

R.H. Odenheiner Co.

R.H. Odenheiner Co.

R.H. Odenheiner Co.

R.H. Odenheiner Co.

Charles D. Moyer

C.S. Gatber \& Sons, Inc

Kermit \$. Snyder

R.H. Odonheiner Co.

R.H. Odenheiner Co.

Kermit \$. Snyder

Harrisburg's Kohl Bros.

C.S. Garber \& Sons, Inc.

Claude Hil. Otter

C.S. Garber \& Sons, Inc.

Lehigh Valley Well \& Pump Co. 1967

Lehigh Valley Well \& Pump Co. 1967

Lehigh Palley Well \& Pump Co. 1968

Miller Pump Service, Inc.
M.B. Biery

R.H. Odenheiner Co.
1923

1951

1948

1947

1944

1927

1930

1955

1959

1961

1963

1966

1952

1957

1960

1957

1953
1964

1966

1962

1961

1961

1955

1955

1967

1964

1959

1967

1965

1958

1967

(1)

1968 
Table 18.--Records of selected wells and springs--Continued

\begin{tabular}{|c|c|c|c|c|c|c|c|c|c|c|}
\hline $\begin{array}{l}\text { Aquifer } \\
\text { code }\end{array}$ & $\begin{array}{c}\text { Depth } \\
\text { of } \\
\text { well } \\
\text { (feet) }\end{array}$ & $\begin{array}{l}\text { Depth } \\
\text { cased } \\
\text { (feet) }\end{array}$ & $\begin{array}{l}\text { Casing } \\
\text { diameter } \\
\text { (inches) }\end{array}$ & $\begin{array}{l}\text { Elevation } \\
\text { of land } \\
\text { surface } \\
\text { (feet) }\end{array}$ & \multicolumn{2}{|c|}{$\begin{array}{l}\text { Water } \\
\text { level } \\
\text { (feet) }\end{array}$} & $\begin{array}{l}\text { Date } \\
\text { water } \\
\text { level } \\
\text { measured }\end{array}$ & $\begin{array}{c}\text { Reported } \\
\text { yield } \\
\text { (gallons } \\
\text { per minute) }\end{array}$ & $\begin{array}{c}\text { Reported } \\
\text { specific } \\
\text { capacity } \\
(\mathrm{gal} / \mathrm{min}) / \mathrm{ft}\end{array}$ & $\begin{array}{l}\text { Local } \\
\text { number }\end{array}$ \\
\hline \multicolumn{11}{|c|}{ BERKS COUNTY } \\
\hline $\begin{array}{l}374 \mathrm{LSVL} \\
374 \mathrm{LSVL} \\
374 \mathrm{LSVL} \\
371 \mathrm{TCKR} \\
371 \mathrm{TCKR}\end{array}$ & $\begin{array}{l}297 \\
248 \\
385 \\
400 \\
400\end{array}$ & $\begin{array}{r}-- \\
220 \\
-- \\
--\end{array}$ & $\begin{array}{r}8 \\
8 \\
8 \\
-- \\
6\end{array}$ & $\begin{array}{l}500 \\
520 \\
430 \\
470 \\
470\end{array}$ & $\begin{array}{r}29.0 \\
92.0 \\
131 \\
-- \\
--\end{array}$ & $\begin{array}{l}\mathrm{R} \\
\mathrm{M} \\
\mathrm{M}\end{array}$ & $\begin{array}{c}03-01-1966 \\
10-01-1971 \\
08-01-1971 \\
\ldots- \\
-\end{array}$ & $\begin{array}{r}192 \\
367 \\
400 \\
-- \\
--\end{array}$ & $\begin{array}{c}2.23 \\
13.3 \\
---\end{array}$ & $\begin{array}{r}\mathrm{BE}-\quad 617 \\
619 \\
623 \\
1049 \\
1050\end{array}$ \\
\hline $\begin{array}{l}371 \mathrm{TCKR} \\
371 \mathrm{ALNN} \\
374 \mathrm{LSVL} \\
374 \mathrm{LSVL} \\
367 \mathrm{EPLR} \\
364 \mathrm{ONLN}\end{array}$ & $\begin{array}{r}500 \\
175 \\
300 \\
77 \\
506 \\
557\end{array}$ & $\begin{array}{r}-- \\
120 \\
94 \\
70 \\
-- \\
--\end{array}$ & $\begin{array}{r}6 \\
6 \\
8 \\
6 \\
12 \\
--\end{array}$ & $\begin{array}{r}470 \\
490 \\
450 \\
1,425 \\
405 \\
420\end{array}$ & $\begin{array}{l}59.5 \\
45 \\
40 \\
7 \\
--\end{array}$ & $\begin{array}{l}\mathbf{R} \\
\mathbf{R} \\
\mathbf{R} \\
\mathbf{R}\end{array}$ & $\begin{array}{c}06-18-1984 \\
01-28-1964 \\
12-05-1975 \\
07-01-1982 \\
--\end{array}$ & $\begin{array}{r}-- \\
20 \\
200 \\
19 \\
300 \\
300\end{array}$ & $\begin{array}{c}--- \\
3.6 \\
19 \\
4.1 \\
1.1\end{array}$ & $\begin{array}{l}1051 \\
1411 \\
1423 \\
1424 \\
1445 \\
1447\end{array}$ \\
\hline \multicolumn{11}{|c|}{ LEHIGH COUNTY } \\
\hline $\begin{array}{l}371 \mathrm{ALNN} \\
371 \mathrm{ALNN} \\
374 \mathrm{LSVL}\end{array}$ & $\begin{array}{l}490 \\
265 \\
311\end{array}$ & $\begin{array}{l}90 \\
90 \\
--\end{array}$ & $\begin{array}{r}6 \\
6 \\
10\end{array}$ & $\begin{array}{l}420 \\
415 \\
425\end{array}$ & $\begin{array}{r}90.0 \\
64.5\end{array}$ & $\begin{array}{l}R \\
M\end{array}$ & $\begin{array}{c}03-01-1964 \\
05-01-1952\end{array}$ & $\begin{array}{r}50 \\
50 \\
450\end{array}$ & $\begin{array}{l}-- \\
--\end{array}$ & $\begin{array}{l}71 \\
72 \\
84\end{array}$ \\
\hline $\begin{array}{l}374 \mathrm{LSVL} \\
374 \mathrm{LSVL} \\
374 \mathrm{LSVL} \\
374 \mathrm{LSVL} \\
364 \mathrm{BKMN}\end{array}$ & $\begin{array}{l}375 \\
525 \\
187 \\
800 \\
276\end{array}$ & $\begin{array}{r}-- \\
166 \\
124 \\
-\overline{100}\end{array}$ & $\begin{array}{r}10 \\
10 \\
10 \\
6 \\
6\end{array}$ & $\begin{array}{l}425 \\
410 \\
465 \\
380 \\
430\end{array}$ & $\begin{array}{r}56.0 \\
44.0 \\
55.0 \\
-- \\
--\end{array}$ & $\begin{array}{l}A \\
M \\
R\end{array}$ & $\begin{array}{c}05-01-1952 \\
05-01-1952 \\
06-01-1951 \\
-- \\
--\end{array}$ & $\begin{array}{r}750 \\
325 \\
350 \\
-- \\
--\end{array}$ & $\begin{array}{r}2.60 \\
175^{--} \\
=-\end{array}$ & $\begin{array}{r}85 \\
86 \\
87 \\
193 \\
207\end{array}$ \\
\hline $\begin{array}{l}371 \mathrm{ALNNN} \\
364 \mathrm{BKMN} \\
364 \mathrm{BKMN} \\
364 \mathrm{BKMN} \\
374 \mathrm{LSVL}\end{array}$ & $\begin{array}{r}1,140 \\
155 \\
145 \\
145 \\
145\end{array}$ & $\begin{array}{r}-- \\
134 \\
126 \\
-- \\
--\end{array}$ & $\begin{array}{l}-- \\
12 \\
12 \\
-- \\
12\end{array}$ & $\begin{array}{l}330 \\
310 \\
310 \\
310 \\
315\end{array}$ & $\begin{array}{r}-- \\
30.0 \\
20.0 \\
-- \\
16.0\end{array}$ & $\begin{array}{l}M \\
M \\
M\end{array}$ & $\begin{array}{r}-- \\
04-01-1941 \\
-- \\
12-01-1954\end{array}$ & $\begin{array}{r}-- \\
390 \\
465 \\
210 \\
--\end{array}$ & $\begin{array}{r}-- \\
32.5 \\
23.2 \\
-- \\
--\end{array}$ & $\begin{array}{l}226 \\
263 \\
265 \\
268 \\
410\end{array}$ \\
\hline $\begin{array}{l}371 \mathrm{ALNN} \\
371 \mathrm{ALNN} \\
371 \mathrm{ALNN} \\
371 \mathrm{ALNN} \\
371 \mathrm{ALNN}\end{array}$ & $\begin{array}{l}400 \\
462 \\
200 \\
185 \\
237\end{array}$ & $\begin{array}{l}-- \\
72 \\
79 \\
40 \\
44\end{array}$ & $\begin{array}{r}8 \\
10 \\
6 \\
6 \\
8\end{array}$ & $\begin{array}{l}360 \\
460 \\
385 \\
365 \\
390\end{array}$ & $\begin{array}{r}125^{--} \\
-- \\
75.0\end{array}$ & $\begin{array}{l}\text { A } \\
\text { R }\end{array}$ & $\begin{array}{ll}-- & \\
-- & \\
-- & \\
- & 1959\end{array}$ & $\begin{array}{r}-- \\
600 \\
65 \\
60 \\
85\end{array}$ & $\begin{array}{l}26 . \overline{-}^{-} \\
32.5 \\
12.0 \\
--\end{array}$ & $\begin{array}{l}463 \\
479 \\
499 \\
500 \\
502\end{array}$ \\
\hline $\begin{array}{l}371 \mathrm{ALNN} \\
371 \mathrm{ALNN} \\
371 \mathrm{ALNN} \\
371 \mathrm{ALNN} \\
377 \mathrm{HRDS}\end{array}$ & $\begin{array}{l}300 \\
305 \\
206 \\
185 \\
350\end{array}$ & $\begin{array}{r}70 \\
14 \\
24 \\
61 \\
106\end{array}$ & $\begin{array}{r}8 \\
12 \\
-8 \\
8 \\
12\end{array}$ & $\begin{array}{l}420 \\
470 \\
415 \\
410 \\
450\end{array}$ & $\begin{array}{r}87.0 \\
140 \\
45.0 \\
60.0 \\
45.0\end{array}$ & $\begin{array}{l}R \\
R \\
R \\
R\end{array}$ & $\begin{array}{l}05-01-1961 \\
05-01-1963 \\
03-01-1963 \\
09-01-1966 \\
05-09-1961\end{array}$ & $\begin{array}{l}140 \\
466 \\
348 \\
400 \\
530\end{array}$ & $\begin{array}{c}8.24 \\
93.2 \\
11.6 \\
6.67 \\
18.0\end{array}$ & $\begin{array}{l}504 \\
505 \\
506 \\
507 \\
521\end{array}$ \\
\hline $\begin{array}{l}371 \mathrm{ALNN} \\
371 \mathrm{ALNN} \\
371 \mathrm{ALNN} \\
371 \mathrm{ALNN} \\
371 \mathrm{ALNN}\end{array}$ & $\begin{array}{l}394 \\
428 \\
352 \\
677 \\
185\end{array}$ & $\begin{array}{l}60 \\
66 \\
39 \\
52 \\
40\end{array}$ & $\begin{array}{r}8 \\
10 \\
8 \\
8 \\
8\end{array}$ & $\begin{array}{l}435 \\
410 \\
370 \\
445 \\
360\end{array}$ & $\begin{array}{r}65.0 \\
48.0 \\
66.0 \\
121 \\
65.0\end{array}$ & $\begin{array}{l}\mathrm{R} \\
\mathrm{R} \\
\mathrm{R} \\
\mathrm{R} \\
\mathrm{M}\end{array}$ & $\begin{array}{l}06-01-1952 \\
04-01-1956 \\
04-01-1957 \\
07-01-1960 \\
08-01-1967\end{array}$ & $\begin{array}{r}225 \\
550 \\
200 \\
150 \\
60\end{array}$ & $\begin{array}{c}22.5 \\
34.4 \\
1.92 \\
1.26 \\
3.00\end{array}$ & $\begin{array}{l}524 \\
525 \\
527 \\
528 \\
529\end{array}$ \\
\hline $\begin{array}{l}371 \mathrm{ALNN} \\
371 \mathrm{ALNN} \\
371 \mathrm{ALNN} \\
364 \mathrm{JKBG} \\
374 \mathrm{LSVL}\end{array}$ & $\begin{array}{l}175 \\
275 \\
265 \\
323 \\
310\end{array}$ & $\begin{array}{r}90 \\
140 \\
42 \\
80 \\
102\end{array}$ & $\begin{array}{l}6 \\
6 \\
6 \\
8 \\
8\end{array}$ & $\begin{array}{l}360 \\
370 \\
410 \\
560 \\
375\end{array}$ & $\begin{array}{r}65.0 \\
.- \\
95.0 \\
23.0 \\
27.0\end{array}$ & $\begin{array}{l}R \\
R \\
M\end{array}$ & $\begin{array}{l}05-01-1957 \\
12-01-1953 \\
06-01-1964 \\
02-01-1967\end{array}$ & $\begin{array}{r}65 \\
75 \\
75 \\
175 \\
440\end{array}$ & $\begin{array}{r}3.82 \\
-- \\
-- \\
1.33 \\
18.3\end{array}$ & $\begin{array}{l}530 \\
531 \\
532 \\
533 \\
544\end{array}$ \\
\hline $\begin{array}{l}\text { 371ALNN } \\
371 \mathrm{ALNN} \\
364 \mathrm{BKMN} \\
364 \mathrm{BKMN} \\
374 \mathrm{LSVL}\end{array}$ & $\begin{array}{l}109 \\
475 \\
120 \\
184 \\
125\end{array}$ & $\begin{array}{l}44 \\
64 \\
26 \\
63 \\
47\end{array}$ & $\begin{array}{r}10 \\
10 \\
6 \\
10 \\
10\end{array}$ & $\begin{array}{l}360 \\
415 \\
365 \\
470 \\
315\end{array}$ & $\begin{array}{r}16.0 \\
134 \\
50.0 \\
75.0 \\
16.0\end{array}$ & $\begin{array}{l}R \\
R \\
R \\
R\end{array}$ & $\begin{array}{l}09-01-1962 \\
10-01-1961 \\
10-01-1961 \\
07-01-1958 \\
08-01-1955\end{array}$ & $\begin{array}{r}600 \\
50 \\
10 \\
500 \\
200\end{array}$ & $\begin{array}{r}46.1 \\
-- \\
125\end{array}$ & $\begin{array}{l}588 \\
593 \\
597 \\
644 \\
677\end{array}$ \\
\hline $\begin{array}{l}364 \mathrm{BKMN} \\
364 \mathrm{BKMN} \\
371 \mathrm{ALNN} \\
371 \mathrm{ALNN} \\
371 \mathrm{ALNN}\end{array}$ & $\begin{array}{l}170 \\
342 \\
334 \\
140 \\
210\end{array}$ & $\begin{array}{r}96 \\
91 \\
184 \\
41 \\
143\end{array}$ & $\begin{array}{r}8 \\
8 \\
10 \\
10 \\
6\end{array}$ & $\begin{array}{l}405 \\
430 \\
490 \\
390 \\
445\end{array}$ & $\begin{array}{r}81.0 \\
142.0 \\
40.0 \\
69.0\end{array}$ & $\begin{array}{l}R \\
R \\
R \\
R\end{array}$ & $\begin{array}{c}-\overline{-} \\
02-01-1967 \\
04-01-1964 \\
06-01-1960 \\
09-01-1959\end{array}$ & $\begin{array}{r}500 \\
140 \\
-- \\
45 \\
50\end{array}$ & $\begin{array}{c}-- \\
-- \\
\overline{0} \\
3.0\end{array}$ & $\begin{array}{l}678 \\
705 \\
710 \\
714 \\
800\end{array}$ \\
\hline $\begin{array}{l}371 \mathrm{ALNN} \\
371 \mathrm{ALNN} \\
371 \mathrm{ALNN} \\
371 \mathrm{ALNN} \\
364 \mathrm{BKMN}\end{array}$ & $\begin{array}{l}300 \\
325 \\
250 \\
100 \\
117\end{array}$ & $\begin{array}{r}60 \\
28 \\
111 \\
58 \\
82\end{array}$ & $\begin{array}{r}6 \\
8 \\
12 \\
6 \\
6\end{array}$ & $\begin{array}{l}445 \\
375 \\
365 \\
360 \\
480\end{array}$ & $\begin{array}{c}100 \\
65.0 \\
-- \\
6.00 \\
78.0\end{array}$ & $\begin{array}{l}R \\
R \\
M \\
M\end{array}$ & $\begin{array}{c}04-01-1967 \\
06-01-1965 \\
-- \\
07-01-1967 \\
07-01-1967\end{array}$ & $\begin{array}{r}40 \\
115 \\
200 \\
74 \\
--\end{array}$ & $\begin{array}{r}-- \\
2.09 \\
-- \\
--\end{array}$ & $\begin{array}{l}801 \\
804 \\
810 \\
860 \\
866\end{array}$ \\
\hline $\begin{array}{l}374 \mathrm{LSVL} \\
371 \mathrm{ALNN} \\
371 \mathrm{ALNN} \\
371 \mathrm{ALNN} \\
364 \mathrm{BKMN}\end{array}$ & $\begin{array}{l}624 \\
286 \\
256 \\
352 \\
260\end{array}$ & $\begin{array}{r}93 \\
167 \\
96 \\
44 \\
84\end{array}$ & $\begin{array}{r}12 \\
6 \\
6 \\
6 \\
6\end{array}$ & $\begin{array}{l}385 \\
437 \\
437 \\
442 \\
392\end{array}$ & $\begin{array}{l}19.0 \\
117 \\
100 \\
118 \\
86.0\end{array}$ & $\begin{array}{l}\mathbf{R} \\
\mathbf{R} \\
\mathbf{R} \\
\mathbf{M} \\
\mathbf{R}\end{array}$ & $\begin{array}{l}08-01-1961 \\
06-01-1967 \\
08-01-1967 \\
04-01-1968 \\
02-01-1968\end{array}$ & $\begin{array}{r}322 \\
30 \\
18 \\
17 \\
--\end{array}$ & $\begin{array}{l}-- \\
.36 \\
.86 \\
.14 \\
--\end{array}$ & $\begin{array}{r}891 \\
937 \\
938 \\
989 \\
1000\end{array}$ \\
\hline
\end{tabular}




\begin{tabular}{|c|c|c|c|c|c|c|}
\hline $\begin{array}{l}\text { Local } \\
\text { number }\end{array}$ & $\begin{array}{l}\text { Site } \\
\text { identification } \\
\text { number }\end{array}$ & Owner & Driller & $\begin{array}{l}\text { Date } \\
\text { drilled }\end{array}$ & $\begin{array}{l}\text { Use } \\
\text { of } \\
\text { site }\end{array}$ & $\begin{array}{l}\text { Use } \\
\text { of } \\
\text { water }\end{array}$ \\
\hline & \multicolumn{6}{|c|}{ LEHIGH COUNTY--Continued } \\
\hline $\begin{array}{r}L E-1107 \\
1108 \\
1109 \\
1274 \\
1275\end{array}$ & $\begin{array}{l}403755075322701 \\
403757075321301 \\
403801075320601 \\
403647075271501 \\
403708075281601\end{array}$ & $\begin{array}{l}\text { IMC Pitman-Moore, Inc. } \\
\text { IMC Pitman-Moore, Inc. } \\
\text { IMC Pitman-Moore, Inc. } \\
\text { Allentown Boat and Swimming Club } \\
\text { Jordan Silk Dyeing Co. }\end{array}$ & $\begin{array}{l}\text { C.S. Garber \& Sons, Inc. } \\
\text { C.S. Garber \& Sons, Inc. } \\
\text { C.S. Garber \& Sons, Inc. } \\
\text {-- }\end{array}$ & $\begin{array}{l}1955 \\
1955 \\
1955 \\
1909 \\
1914\end{array}$ & $\begin{array}{l}W \\
W \\
W \\
W \\
W\end{array}$ & $\begin{array}{l}\mathrm{N} \\
\mathrm{N} \\
\mathrm{N} \\
\mathrm{H} \\
\mathrm{N}\end{array}$ \\
\hline $\begin{array}{l}1284 \\
1285 \\
1286 \\
1287 \\
1289\end{array}$ & $\begin{array}{l}403305075375801 \\
403105075341501 \\
403508075254501 \\
403525075420101 \\
403442075373501\end{array}$ & $\begin{array}{l}\text { Siravo, Anthony } \\
\text { Mack Trucks, Inc. } \\
\text { Orendach, Robert } \\
\text { Ryder Truck, Inc. } \\
\text { Lehigh County Authority }\end{array}$ & $\begin{array}{l}\text { William \$tothoff Co. } \\
\text { Wiliam Stothoff Co. }\end{array}$ & $\begin{array}{l}1981 \\
1975 \\
1910 \\
-- \\
1970\end{array}$ & $\begin{array}{l}W \\
W \\
W \\
W \\
W\end{array}$ & $\begin{array}{l}\mathrm{H} \\
\mathrm{H} \\
\mathrm{U} \\
\mathrm{H} \\
\mathrm{P}\end{array}$ \\
\hline $\begin{array}{l}1290 \\
1291 \\
1292 \\
1293 \\
1294\end{array}$ & $\begin{array}{l}403356075365901 \\
403449075384701 \\
403524075362401 \\
403230075321201 \\
403143075331202\end{array}$ & $\begin{array}{l}\text { Lehigh County Authority } \\
\text { Lehigh County Authority } \\
\text { Lehigh County Authority } \\
\text { Lehigh County Authority } \\
\text { Lehigh County Authority }\end{array}$ & $\begin{array}{l}\text { William Stothoff Co. } \\
\text { Harrisburg's Kohl Bros. } \\
\text { Harrisburg's Kohl Bros. } \\
\text { C.S. Garber \& Sons, Inc. } \\
\text { Harrisburg's Kohl Bros. }\end{array}$ & $\begin{array}{l}1970 \\
1971 \\
1972 \\
1974 \\
1973\end{array}$ & $\begin{array}{l}W \\
W \\
W \\
W \\
W\end{array}$ & $\begin{array}{l}\mathrm{P} \\
\mathrm{P} \\
\mathrm{P} \\
\mathrm{P} \\
\mathrm{P}\end{array}$ \\
\hline $\begin{array}{l}1295 \\
1297 \\
1298 \\
1299 \\
1300\end{array}$ & $\begin{array}{l}403149075354101 \\
403504075371901 \\
403404075330601 \\
403317075311301 \\
403143075352901\end{array}$ & $\begin{array}{l}\text { Lehigh County Authority } \\
\text { G.R. Insurance Co. } \\
\text { Pearl, Don } \\
\text { Rodale, Robert } \\
\text { Lehigh County Authority }\end{array}$ & $\begin{array}{l}\text { C.S. Garber \& Sons, Inc. } \\
\text { C.S. Garber \& Sons, Inc. } \\
\text { C.S. Garber \& Sons, Inc. }\end{array}$ & $\begin{array}{l}1971 \\
1900 \\
1975 \\
1964 \\
1972\end{array}$ & $\begin{array}{l}W \\
U \\
W \\
W \\
W\end{array}$ & $\begin{array}{l}\mathrm{P} \\
\mathrm{U} \\
\mathrm{H} \\
\mathrm{H} \\
\mathrm{P}\end{array}$ \\
\hline $\begin{array}{l}1305 \\
1306 \\
1307 \\
1308 \\
1309\end{array}$ & $\begin{array}{l}403902075301502 \\
403818075304101 \\
403759075291301 \\
403742075291201 \\
403819075302001\end{array}$ & $\begin{array}{l}\text { Whitehall Twp. Authority } \\
\text { Whitehall Twp. Authority } \\
\text { Whitehall Twp. Authority } \\
\text { Whitehall Twp. Authority } \\
\text { Whitehall Twp. Authority }\end{array}$ & $\begin{array}{l}\text { Terry } M . \text { Mayer } \\
\text { Terry M. Mayer } \\
\text { Terry } M \text {. Mayer } \\
\text { Terry } M \text {. Mayer } \\
\text { Terry M. Mayer }\end{array}$ & $\begin{array}{l}1984 \\
1984 \\
1984 \\
1984 \\
1984\end{array}$ & $\begin{array}{l}W \\
\mathrm{U} \\
Z \\
\mathrm{U} \\
Z\end{array}$ & $\begin{array}{l}P \\
\mathbf{U} \\
\mathbf{U} \\
\mathbf{U} \\
\mathbf{U}\end{array}$ \\
\hline $\begin{array}{l}1312 \\
1313 \\
1314 \\
1315 \\
1318\end{array}$ & $\begin{array}{l}403742075343701 \\
403531075333801 \\
403533075334201 \\
403457075315401 \\
403224075304701\end{array}$ & $\begin{array}{l}\text { S. Whitehall Twp. Authority } \\
\text { S. Whitehall Twp. Authority } \\
\text { S. Whitehall Twp. Authority } \\
\text { S. Whitehall Twp. Authority } \\
\text { Emmaus Borough }\end{array}$ & $\begin{array}{l}\text { R.H. Odenheiner Co. } \\
\text { R.H. Odenheiner Co. } \\
\text { R.H. Odenheiner Co. } \\
\text { Layne-New York Co., Inc. }\end{array}$ & $\begin{array}{l}1966 \\
1970 \\
1982 \\
1985 \\
1973\end{array}$ & $\begin{array}{l}W \\
W \\
W \\
W \\
W\end{array}$ & $\begin{array}{l}\mathrm{P} \\
\mathrm{P} \\
\mathrm{P} \\
\mathrm{P} \\
\mathrm{P}\end{array}$ \\
\hline $\begin{array}{l}1319 \\
1320 \\
1321 \\
1322 \\
1323\end{array}$ & $\begin{array}{l}403403075375501 \\
403453075322301 \\
403134075335001 \\
403545075311901 \\
403357075312101\end{array}$ & $\begin{array}{l}\text { Lehigh County Authority } \\
\text { Hunsicker, Horace } \\
\text { Lehigh County Authority } \\
\text { Lehigh County Authority } \\
\text { Lehigh County Authority }\end{array}$ & $\begin{array}{l}\text { Eichelberger Well Drlg., Inc. } \\
\text { Kermit S. Snyder } \\
\text { C.S. Garber \& Sons, Inc. } \\
\text {-- }\end{array}$ & $\begin{array}{l}1985 \\
1963 \\
1976 \\
1969 \\
1976\end{array}$ & $\begin{array}{l}W \\
W \\
W \\
W \\
W\end{array}$ & $\begin{array}{l}\mathrm{P} \\
\mathrm{Z} \\
\mathrm{P} \\
\mathrm{P} \\
\mathrm{P}\end{array}$ \\
\hline $\begin{array}{l}1326 \\
1327 \\
1331 \\
1332 \\
1335\end{array}$ & $\begin{array}{l}403406075331501 \\
403342075341001 \\
403725075271901 \\
403057075342501 \\
403818075300302\end{array}$ & $\begin{array}{l}\text { Wescosville Professional Park } \\
\text { Duford, Rolland } \\
\text { AT\&T Technologies } \\
\text { Mack Trucks, Inc. } \\
\text { Whitehall Twp. Authority }\end{array}$ & $\begin{array}{l}\text { Terry M. Mayer } \\
\text { William Stothoff Co. }\end{array}$ & $\begin{array}{l}1986 \\
1986 \\
1979 \\
1974 \\
1975\end{array}$ & $\begin{array}{l}W \\
W \\
W \\
W \\
W\end{array}$ & $\begin{array}{l}\mathrm{H} \\
\mathrm{H} \\
\mathrm{N} \\
\mathrm{N} \\
\mathrm{P}\end{array}$ \\
\hline $\begin{array}{l}1336 \\
1337 \\
1338 \\
1339 \\
1340\end{array}$ & $\begin{array}{l}403710075342101 \\
403700075341201 \\
403708075341901 \\
403818075300303 \\
403856075311001\end{array}$ & $\begin{array}{l}\text { Alpo Pet Foods, Inc. } \\
\text { Alpo Pet Foods, Inc. } \\
\text { Alpo Pet Foods, Inc. } \\
\text { Whitehall Twp. Authority } \\
\text { Whitehall Twp. Authority }\end{array}$ & $\begin{array}{l}\text { Moody Drilling Co. } \\
\text { Moody Drilling Co. } \\
\text { Eichelberger Well Drlg., Inc. } \\
\\
\ldots\end{array}$ & $\begin{array}{l}1970 \\
1972 \\
1983 \\
1985 \\
1986\end{array}$ & $\begin{array}{l}W \\
W \\
W \\
W \\
W\end{array}$ & $\begin{array}{l}N \\
N \\
N \\
P \\
P\end{array}$ \\
\hline $\begin{array}{l}1341 \\
1342 \\
1343 \\
1344 \\
1345\end{array}$ & $\begin{array}{l}403024075353401 \\
403839075280301 \\
403229075394701 \\
403226075395302 \\
403230075393801\end{array}$ & $\begin{array}{l}\text { Alburtis Water Authority } \\
\text { Tarketts, Inc. } \\
\text { Shellhamer, Daniel } \\
\text { Shellhamer, Daniel } \\
\text { Shellhamer, Durell }\end{array}$ & $\begin{array}{l}\text { Joseph M. Mayer } \\
\text { R.H. Odenheiner Co. } \\
\text { R.H. Odenheiner Co. } \\
\text { R.H. Odenheiner Co. } \\
\text { Terry M. Mayer }\end{array}$ & $\begin{array}{l}1977 \\
1971 \\
1959 \\
1963 \\
1970\end{array}$ & $\begin{array}{l}W \\
W \\
W \\
W \\
W\end{array}$ & $\begin{array}{l}\mathrm{P} \\
\mathrm{N} \\
\mathrm{P} \\
\mathrm{P} \\
\mathrm{C}\end{array}$ \\
\hline $\begin{array}{l}1346 \\
1347 \\
1348 \\
1349 \\
1351\end{array}$ & $\begin{array}{l}403647075325001 \\
403647075325002 \\
403648075331101 \\
403432075324401 \\
403401075375001\end{array}$ & $\begin{array}{l}\text { Country Club Gardens Water Co. } \\
\text { Country Club Gardens Water Co. } \\
\text { Country Club Gardens Water Co. } \\
\text { Cedarbrook } \\
\text { Muth }\end{array}$ & $\begin{array}{l}\text { R.H. Odenheiner Co. } \\
\text { R.H. Odenheiner Co. } \\
\text { Joseph M. Mayer } \\
\text { Larry D. Welshhans } \\
\end{array}$ & $\begin{array}{l}1974 \\
1971 \\
1974 \\
1977 \\
--\end{array}$ & $\begin{array}{l}W \\
W \\
W \\
W \\
W\end{array}$ & $\begin{array}{l}\mathrm{P} \\
\mathrm{P} \\
\mathrm{P} \\
\mathrm{T} \\
\mathrm{H}\end{array}$ \\
\hline $\begin{array}{l}1353 \\
1354 \\
1355 \\
1356 \\
1357\end{array}$ & $\begin{array}{l}403400075385501 \\
403423075385501 \\
403422075374201 \\
403432075375401 \\
403418075370201\end{array}$ & $\begin{array}{l}\text { Unknown } \\
\text { Lehigh County Authority } \\
\text { Stroh Brewery Co. } \\
\text { Stroh Brewery Co. } \\
\text { Stroh Brewery Co. }\end{array}$ & $\begin{array}{lll} & \\
-- & & \\
\text { Pennsylvania Drilling Co. } \\
\text { Pennsylvania Drilling Co. } \\
\text { Pennsylvania Drilling Co. }\end{array}$ & $\begin{array}{l}-\overline{1} \\
1985 \\
1985 \\
1985 \\
1985\end{array}$ & $\begin{array}{l}W \\
0 \\
W \\
0 \\
0\end{array}$ & $\begin{array}{l}\mathrm{H} \\
\mathrm{U} \\
\mathrm{N} \\
\mathrm{U} \\
\mathrm{U}\end{array}$ \\
\hline $\begin{array}{l}1358 \\
1359 \\
1369\end{array}$ & $\begin{array}{l}403428075370201 \\
403648075331102 \\
403757075321901\end{array}$ & $\begin{array}{l}\text { Torola } \\
\text { Country Club Gardens Water Co. } \\
\text { IMC Pitman-Moore, Inc. }\end{array}$ & R.H. Odenheiner Co. & 1972 & $\begin{array}{l}W \\
W \\
W\end{array}$ & $\begin{array}{l}\mathrm{C} \\
\mathrm{P} \\
\mathrm{N}\end{array}$ \\
\hline $\begin{array}{r}L E-S p-14 \\
S p-15\end{array}$ & $\begin{array}{l}403543075285301 \\
403447075331801\end{array}$ & $\begin{array}{l}\text { City of Allentown (Crystal Spring) } \\
\text { City of Allentown (Schantz Spring) }\end{array}$ & -- & -- & $\begin{array}{l}W \\
W\end{array}$ & $\begin{array}{l}\mathbf{P} \\
\mathbf{P}\end{array}$ \\
\hline
\end{tabular}


Table 18.--Records of selected wells and springs--Continued

\begin{tabular}{|c|c|c|c|c|c|c|c|c|c|c|}
\hline $\begin{array}{l}\text { Aquifer } \\
\text { code }\end{array}$ & $\begin{array}{c}\text { Depth } \\
\text { of } \\
\text { well } \\
\text { (feet) }\end{array}$ & $\begin{array}{l}\text { Depth } \\
\text { cased } \\
\text { (feet) }\end{array}$ & $\begin{array}{l}\text { Casing } \\
\text { diameter } \\
\text { (inches) }\end{array}$ & $\begin{array}{l}\text { Elevation } \\
\text { of land } \\
\text { surface } \\
\text { (feet) }\end{array}$ & $\begin{array}{l}\text { Wate } \\
\text { leve } \\
\text { (feet }\end{array}$ & & $\begin{array}{l}\text { Date } \\
\text { water } \\
\text { level } \\
\text { measured }\end{array}$ & $\begin{array}{c}\text { Reported } \\
\text { yield } \\
\text { (gallons } \\
\text { per minute) }\end{array}$ & $\begin{array}{l}\text { Reported } \\
\text { specific } \\
\text { capacity } \\
(\mathrm{gal} / \mathrm{min}) / \mathrm{ft}\end{array}$ & $\begin{array}{l}\text { Local } \\
\text { number }\end{array}$ \\
\hline \multicolumn{11}{|c|}{ LEHIGH COUNTY--Continued } \\
\hline $\begin{array}{l}\text { 367EPLR } \\
367 \text { EPLR } \\
367 \text { EPLR } \\
371 \text { ALNN } \\
\text { 371ALNN }\end{array}$ & $\begin{array}{l}170 \\
164 \\
168 \\
100 \\
100\end{array}$ & $\begin{array}{r}122 \\
126 \\
140 \\
-- \\
--\end{array}$ & $\begin{array}{r}12 \\
12 \\
12 \\
6 \\
8\end{array}$ & $\begin{array}{l}315 \\
320 \\
310 \\
250 \\
320\end{array}$ & $\begin{array}{l}-- \\
-- \\
-- \\
--\end{array}$ & & $\begin{array}{l}-- \\
-- \\
--\end{array}$ & $\begin{array}{r}-- \\
-- \\
-- \\
40 \\
100\end{array}$ & $\begin{array}{l}-- \\
-- \\
-- \\
--\end{array}$ & $\begin{array}{r}\text { LE- } 1107 \\
1108 \\
1109 \\
1274 \\
1275\end{array}$ \\
\hline $\begin{array}{l}\text { 364 JKBGR } \\
371 \mathrm{ALNN} \\
374 \mathrm{LSVL} \\
364 \mathrm{BKMN} \\
364 \mathrm{JKBGC}\end{array}$ & $\begin{array}{r}130 \\
240 \\
-- \\
-\overline{-}\end{array}$ & $\begin{array}{r}-\overline{107} \\
\overline{--} \\
\overline{52}\end{array}$ & $\begin{array}{r}-- \\
-- \\
-- \\
12\end{array}$ & $\begin{array}{r}50 \\
410 \\
520 \\
460 \\
450\end{array}$ & $\begin{array}{c}18.8 \\
25.8 \\
6.05 \\
-. \\
79.0\end{array}$ & $\begin{array}{l}\mathrm{R} \\
\mathrm{R} \\
\mathrm{M} \\
\mathrm{R}\end{array}$ & $\begin{array}{l}06-26-1984 \\
07-03-1984 \\
07-16-1984 \\
07-26-1984 \\
05-01-1984\end{array}$ & $\begin{array}{r}325 \\
\overline{--} \\
1,010\end{array}$ & $\begin{array}{c}4 . \overline{6} \\
-- \\
33 . \overline{6}\end{array}$ & $\begin{array}{l}1284 \\
1285 \\
1286 \\
1287 \\
1289\end{array}$ \\
\hline $\begin{array}{l}364 \mathrm{BKMN} \\
364 \mathrm{BKMN} \\
364 \mathrm{JKBGC} \\
371 \mathrm{ALNN} \\
371 \mathrm{ALNN}\end{array}$ & $\begin{array}{l}350 \\
400 \\
400 \\
295 \\
130\end{array}$ & $\begin{array}{r}184 \\
37 \\
37 \\
152 \\
40\end{array}$ & $\begin{array}{r}10 \\
24 \\
24 \\
8 \\
6\end{array}$ & $\begin{array}{l}430 \\
470 \\
465 \\
410 \\
400\end{array}$ & $\begin{array}{r}56 \\
75 \\
61.0 \\
115 \\
64.0\end{array}$ & $\begin{array}{l}\mathbf{R} \\
\mathbf{R} \\
\mathbf{R}\end{array}$ & $\begin{array}{r}05-01-1984 \\
1984 \\
05-01-1984 \\
05-01-1984 \\
05-01-1984\end{array}$ & $\begin{array}{r}1,000 \\
695 \\
850 \\
367 \\
200\end{array}$ & $\begin{array}{r}200 \\
23 \\
23 \\
52 \\
29\end{array}$ & $\begin{array}{l}1290 \\
1291 \\
1292 \\
1293 \\
1294\end{array}$ \\
\hline $\begin{array}{l}371 \text { ALNN } \\
364 \mathrm{JKBGR} \\
371 \mathrm{ALNN} \\
371 \mathrm{ALNN} \\
371 \mathrm{ALNN}\end{array}$ & $\begin{array}{r}184 \\
20 \\
-- \\
-- \\
360\end{array}$ & $\begin{array}{r}71 \\
-- \\
-- \\
135\end{array}$ & $\begin{array}{r}8 \\
-- \\
6 \\
6 \\
8\end{array}$ & $\begin{array}{l}400 \\
475 \\
400 \\
375 \\
430\end{array}$ & $\begin{array}{l}55.0 \\
11.1 \\
-.-5 \\
63.5 \\
67\end{array}$ & $\begin{array}{l}R \\
M\end{array}$ & $\begin{array}{l}05-01-1984 \\
08-09-1984 \\
08-09-1984 \\
08-09-1984 \\
05-01-1984\end{array}$ & $\begin{array}{r}500 \\
-- \\
-- \\
200\end{array}$ & $\begin{array}{r}125 \\
\ldots \\
1 . \\
1 .\end{array}$ & $\begin{array}{l}1295 \\
1297 \\
1298 \\
1299 \\
1300\end{array}$ \\
\hline $\begin{array}{l}\text { 367EPLR } \\
371 \mathrm{ALNN} \\
371 \mathrm{ALNN} \\
\text { 367EPLR } \\
\text { 371ALNN }\end{array}$ & $\begin{array}{l}150 \\
280 \\
400 \\
400 \\
300\end{array}$ & $\begin{array}{l}60 \\
90 \\
23 \\
43 \\
80\end{array}$ & $\begin{array}{r}8 \\
10 \\
6 \\
6 \\
6\end{array}$ & $\begin{array}{l}365 \\
395 \\
400 \\
320 \\
385\end{array}$ & $\begin{array}{r}88.9 \\
-- \\
32 \\
150\end{array}$ & $\begin{array}{l}\mathrm{R} \\
\mathrm{R}\end{array}$ & $\begin{array}{c}09-10-1984 \\
-- \\
-- \\
07-\quad-1984 \\
09-\quad-1984\end{array}$ & $\begin{array}{r}300 \\
20 \\
10 \\
39 \\
3\end{array}$ & $\begin{array}{r}17 \\
.-12 \\
.13 \\
.13 \\
.02\end{array}$ & $\begin{array}{l}1305 \\
1306 \\
1307 \\
1308 \\
1309\end{array}$ \\
\hline $\begin{array}{l}367 \text { EPLR } \\
364 \text { BKMN } \\
364 \text { BKMN } \\
371 \mathrm{ALNN} \\
371 \mathrm{ALNN}\end{array}$ & $\begin{array}{l}-\overline{144} \\
300 \\
262 \\
400\end{array}$ & $\begin{array}{r}-- \\
-- \\
60 \\
125 \\
150\end{array}$ & $\begin{array}{r}-- \\
-- \\
8 \\
8 \\
10\end{array}$ & $\begin{array}{l}370 \\
430 \\
430 \\
315 \\
370\end{array}$ & $\begin{array}{l}62 \\
47 \\
63 \\
27.2 \\
45\end{array}$ & $\begin{array}{l}\mathrm{R} \\
\mathrm{R}\end{array}$ & $\begin{array}{l}07-28-1982 \\
05-01-1984 \\
05-02-1984 \\
03-11-1985 \\
09-19-1973\end{array}$ & $\begin{array}{r}65 \\
80 \\
475 \\
481 \\
546\end{array}$ & $\begin{array}{l}65 \\
11 \\
26.4 \\
10 \\
26\end{array}$ & $\begin{array}{l}1312 \\
1313 \\
1314 \\
1315 \\
1318\end{array}$ \\
\hline $\begin{array}{l}364 \text { BKMN } \\
371 \text { ALNN } \\
371 \mathrm{ALNN} \\
371 \mathrm{ALNN} \\
371 \mathrm{ALNN}\end{array}$ & $\begin{array}{l}200 \\
355 \\
272 \\
400 \\
425\end{array}$ & $\begin{array}{r}119 \\
69 \\
215 \\
68 \\
83\end{array}$ & $\begin{array}{r}12 \\
8 \\
8 \\
8 \\
8\end{array}$ & $\begin{array}{l}450 \\
390 \\
435 \\
470 \\
440\end{array}$ & $\begin{array}{l}55.9 \\
60 \\
92 \\
155 \\
123\end{array}$ & $\begin{array}{l}\mathrm{M} \\
\mathrm{R} \\
\mathrm{R}\end{array}$ & $\begin{array}{l}06-27-1985 \\
12-19-1963 \\
01-12-1976 \\
01-23-1969 \\
07-27-1976\end{array}$ & $\begin{array}{r}2,000 \\
-- \\
298 \\
90 \\
90\end{array}$ & $\begin{array}{c}330 \\
7.6 \\
3 . \\
.71\end{array}$ & $\begin{array}{l}1319 \\
1320 \\
1321 \\
1322 \\
1323\end{array}$ \\
\hline $\begin{array}{l}\text { 371ALNN } \\
371 \text { ALNN } \\
371 \text { ALNN } \\
371 \text { ALNN } \\
\text { 371ALNN }\end{array}$ & $\begin{array}{r}85 \\
145 \\
170 \\
355 \\
270\end{array}$ & $\begin{array}{r}-- \\
-- \\
91 \\
185 \\
59\end{array}$ & $\begin{array}{l}6 \\
6 \\
8 \\
8 \\
6\end{array}$ & $\begin{array}{l}390 \\
460 \\
295 \\
410 \\
415\end{array}$ & $\begin{array}{c}59.8 \\
116 \\
40 \\
43 \\
142\end{array}$ & $\begin{array}{l}\mathrm{R} \\
\mathrm{R} \\
\mathrm{R} \\
\mathrm{R} \\
\mathrm{R}\end{array}$ & $\begin{array}{r}01-09-1986 \\
01-09-1986 \\
05-07-1986 \\
12-10-1974 \\
1985\end{array}$ & $\begin{array}{r}-- \\
475 \\
200 \\
50\end{array}$ & $\begin{array}{l}-- \\
4.8 \\
2.4 \\
8.3\end{array}$ & $\begin{array}{l}1326 \\
1327 \\
1331 \\
1332 \\
1335\end{array}$ \\
\hline $\begin{array}{l}364 \text { BKMN } \\
361 \text { MRBG } \\
364 \text { BKMN } \\
371 \text { ALNN } \\
371 \text { ALNN }\end{array}$ & $\begin{array}{l}522 \\
410 \\
700 \\
400 \\
350\end{array}$ & $\begin{array}{r}170 \\
87 \\
252 \\
-- \\
--\end{array}$ & $\begin{array}{r}8 \\
8 \\
12 \\
-- \\
--\end{array}$ & $\begin{array}{r}1,420 \\
460 \\
440 \\
415 \\
370\end{array}$ & $\begin{array}{r}96 \\
121 \\
125 \\
-- \\
--\end{array}$ & $\begin{array}{l}\mathrm{R} \\
\mathrm{R} \\
\mathrm{R}\end{array}$ & $\begin{array}{c}04-22-1970 \\
02-29-1972 \\
11-08-1983 \\
-- \\
-\end{array}$ & $\begin{array}{l}500 \\
120 \\
600 \\
-\overline{548}\end{array}$ & $\begin{array}{l}125 \\
120 \\
150 \\
180^{--}\end{array}$ & $\begin{array}{l}1336 \\
1337 \\
1338 \\
1339 \\
1340\end{array}$ \\
\hline $\begin{array}{l}\text { 374LSVL } \\
364 \mathrm{BKMN} \\
361 \mathrm{BSKL} \\
361 \mathrm{BSKL} \\
361 \mathrm{BSKL}\end{array}$ & $\begin{array}{r}216 \\
430 \\
207 \\
293 \\
97\end{array}$ & $\begin{array}{r}114 \\
36 \\
-- \\
-- \\
--\end{array}$ & $\begin{array}{r}8 \\
15 \\
6 \\
6 \\
6\end{array}$ & $\begin{array}{l}425 \\
275 \\
500 \\
460 \\
450\end{array}$ & $\begin{array}{l}39 \\
30 \\
-- \\
--\end{array}$ & $\begin{array}{l}\mathrm{R} \\
\mathrm{R}\end{array}$ & $\begin{array}{c}03-10-1977 \\
01-15-1971 \\
-- \\
-- \\
--\end{array}$ & $\begin{array}{r}125 \\
1,080 \\
-- \\
--\end{array}$ & $\begin{array}{r}22.8 \\
-- \\
--\end{array}$ & $\begin{array}{l}1341 \\
1342 \\
1343 \\
1344 \\
1345\end{array}$ \\
\hline $\begin{array}{l}364 \mathrm{BKMN} \\
364 \mathrm{BKMNN} \\
364 \mathrm{BKMN} \\
371 \mathrm{ALNN} \\
364 \mathrm{BKMN}\end{array}$ & $\begin{array}{l}227 \\
350 \\
401 \\
300 \\
140\end{array}$ & $\begin{array}{l}65 \\
95 \\
87 \\
64 \\
--\end{array}$ & $\begin{array}{l}6 \\
6 \\
6 \\
8 \\
6\end{array}$ & $\begin{array}{l}470 \\
470 \\
510 \\
370 \\
450\end{array}$ & $\begin{array}{l}73 \\
70 \\
80 \\
45 \\
-\end{array}$ & $\begin{array}{l}\mathbf{R} \\
\mathbf{R} \\
\mathbf{R} \\
\mathbf{R}\end{array}$ & $\begin{array}{c}10-20-1987 \\
01-07-1971 \\
09-10-1974 \\
08-24-1977 \\
--\end{array}$ & $\begin{array}{r}72 \\
60 \\
55 \\
360 \\
--\end{array}$ & $\begin{array}{r}72 \\
120 \\
.32 \\
-- \\
--\end{array}$ & $\begin{array}{l}1346 \\
1347 \\
1348 \\
1349 \\
1351\end{array}$ \\
\hline $\begin{array}{l}364 \mathrm{BKMN} \\
364 \mathrm{BKMN} \\
364 \mathrm{BKMN} \\
364 \mathrm{BKMN} \\
364 \mathrm{BKMN}\end{array}$ & $\begin{array}{r}55 \\
45 \\
250 \\
228 \\
230\end{array}$ & $\begin{array}{r}-- \\
-6 \\
85 \\
58\end{array}$ & $\begin{array}{r}-- \\
-- \\
6 \\
6\end{array}$ & $\begin{array}{l}465 \\
460 \\
430 \\
440 \\
435\end{array}$ & $\begin{array}{l}-- \\
-- \\
-- \\
--\end{array}$ & & $\begin{array}{l}-- \\
-- \\
-- \\
--\end{array}$ & $\begin{array}{l}-- \\
-- \\
-- \\
--\end{array}$ & $\begin{array}{l}-- \\
-- \\
-- \\
--\end{array}$ & $\begin{array}{l}1353 \\
1354 \\
1355 \\
1356 \\
1357\end{array}$ \\
\hline $\begin{array}{l}364 \text { BKMN } \\
364 \text { BKMN } \\
367 \text { EPLR }\end{array}$ & $\begin{array}{r}80 \\
350 \\
160\end{array}$ & $\begin{array}{r}-- \\
93 \\
110\end{array}$ & $\begin{array}{r}-- \\
12\end{array}$ & $\begin{array}{l}440 \\
510 \\
310\end{array}$ & $126^{--}$ & $\mathbf{R}$ & $03-\overline{17}-1972$ & 65 & $2 . \overline{--}$ & $\begin{array}{l}1358 \\
1359 \\
1369\end{array}$ \\
\hline $\begin{array}{l}\text { 371ALNN } \\
364 \mathrm{BKMN}\end{array}$ & -- & -- & -- & $\begin{array}{l}265 \\
340\end{array}$ & -- & & -- & $\begin{array}{l}2,800 \\
8,500\end{array}$ & $=-$ & $\begin{array}{r}\text { LE-Sp-14 } \\
\text { Sp-15 }\end{array}$ \\
\hline
\end{tabular}

